\title{
THE FISHERIES OF
}
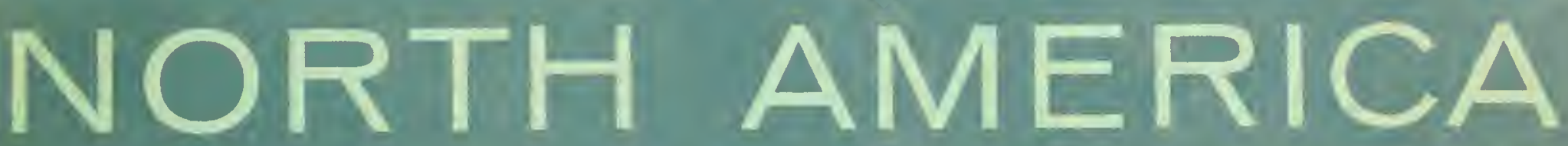

$20 x-5=$

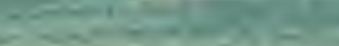

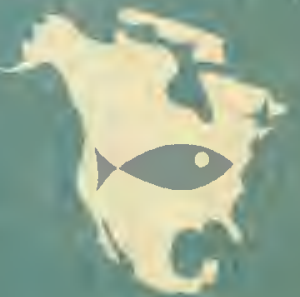

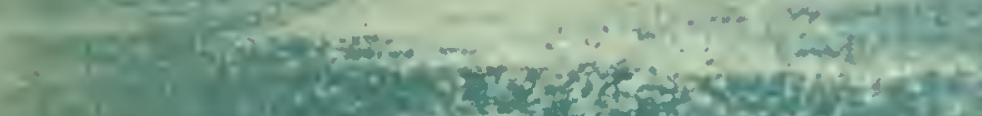

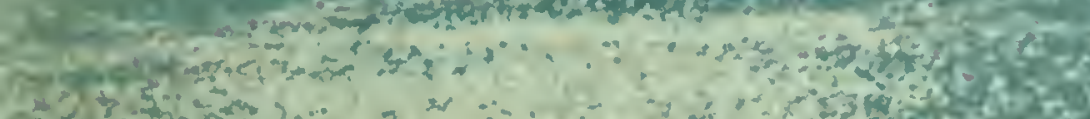

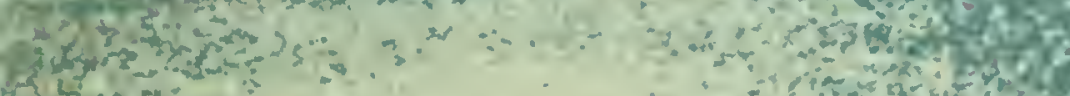

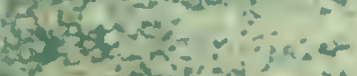

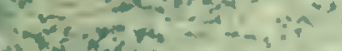

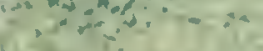

$\therefore=0$

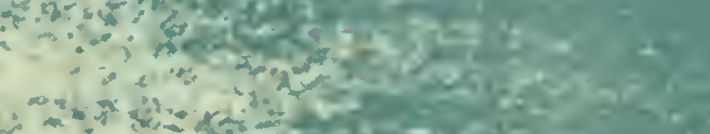

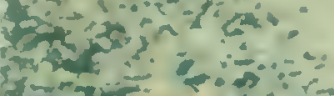

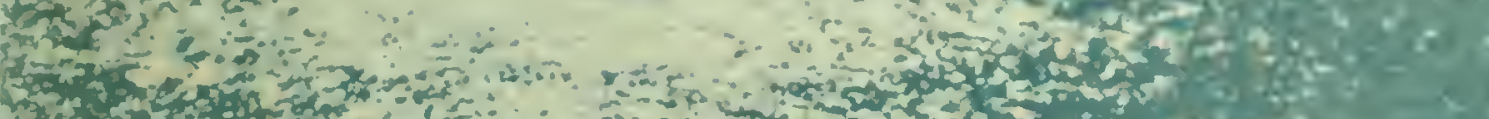

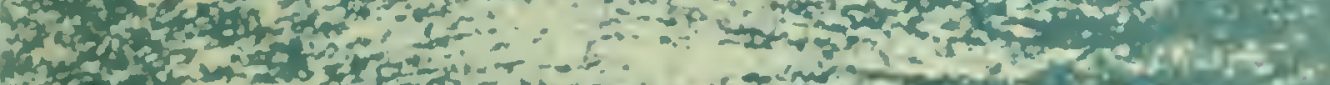

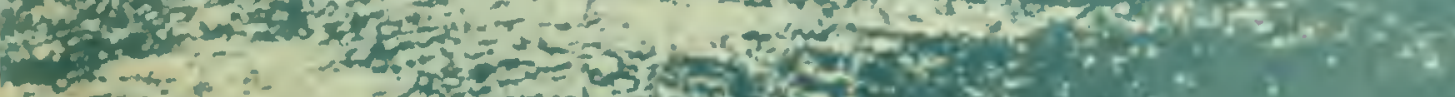

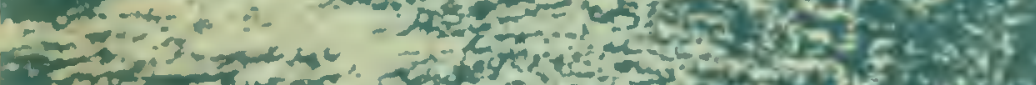

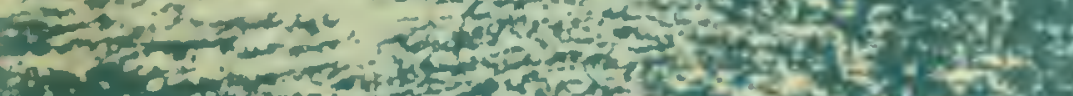

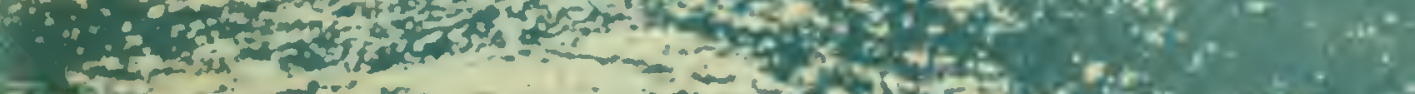

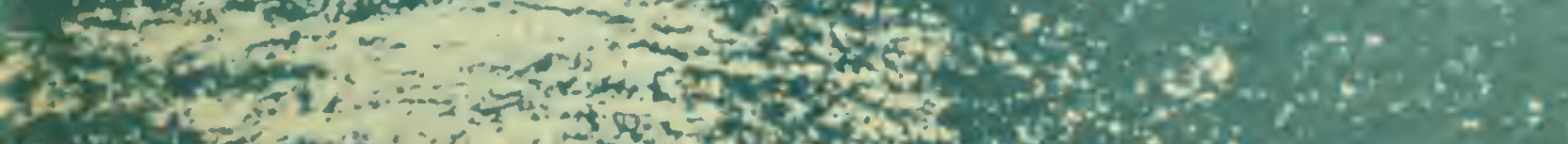

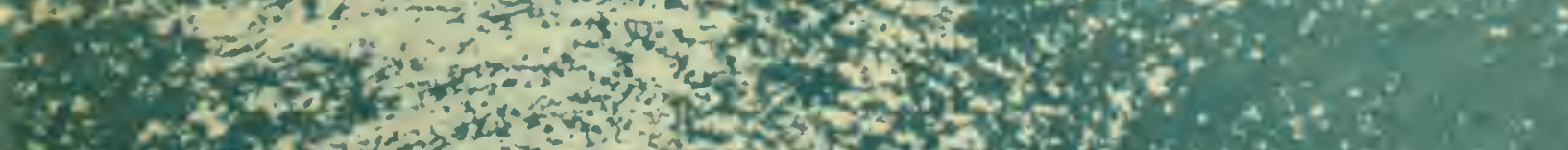

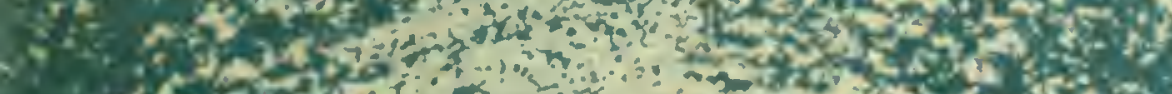

4.

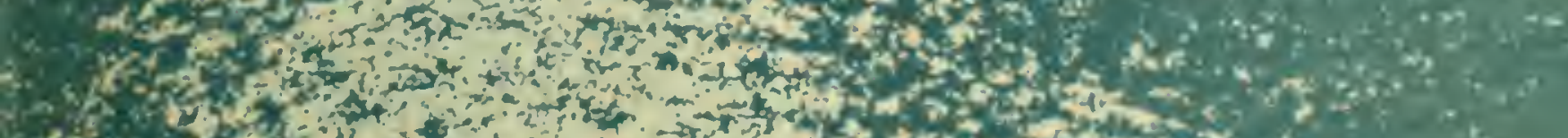

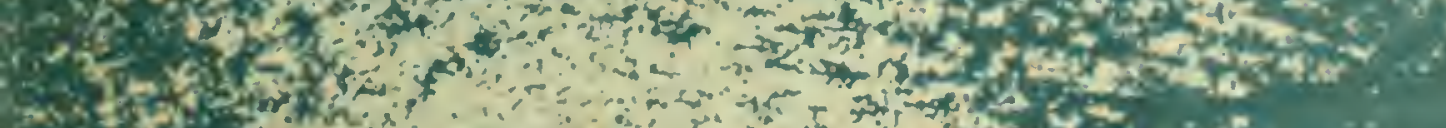

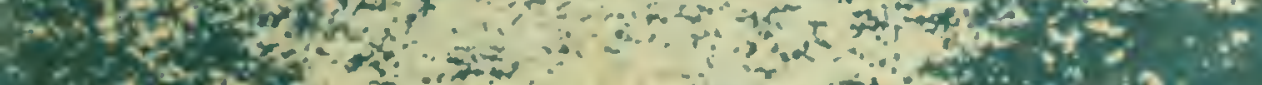

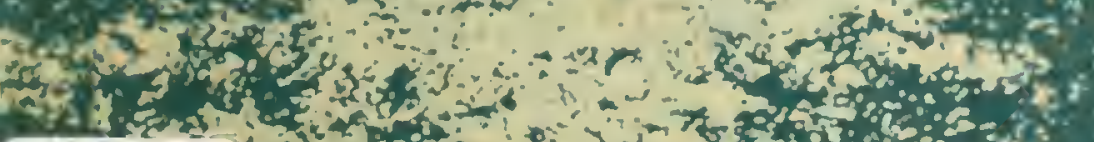
$\mathrm{SH}$
219
N67

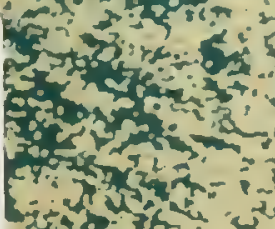

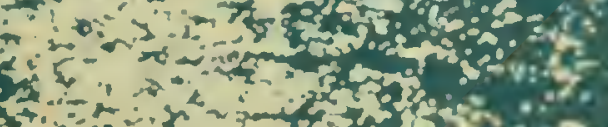

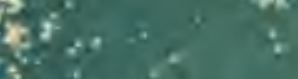
1966

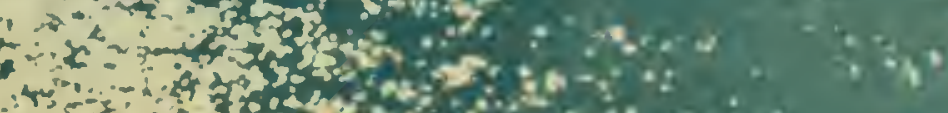

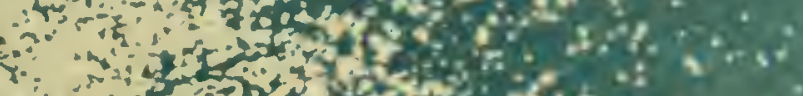

(5)

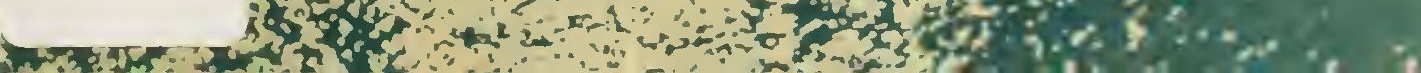




\section{THE OCEAN covers about three quarters of the world's}

surface. The coastlines of North America are about 20 percent of the world total-but the marine production of the countries of this continent is only about 9 percent of the world total.

The present world catch is about 50 million metric tons. Some scientists believe this is as little as 10 percent of the potential catch, perhaps even less.

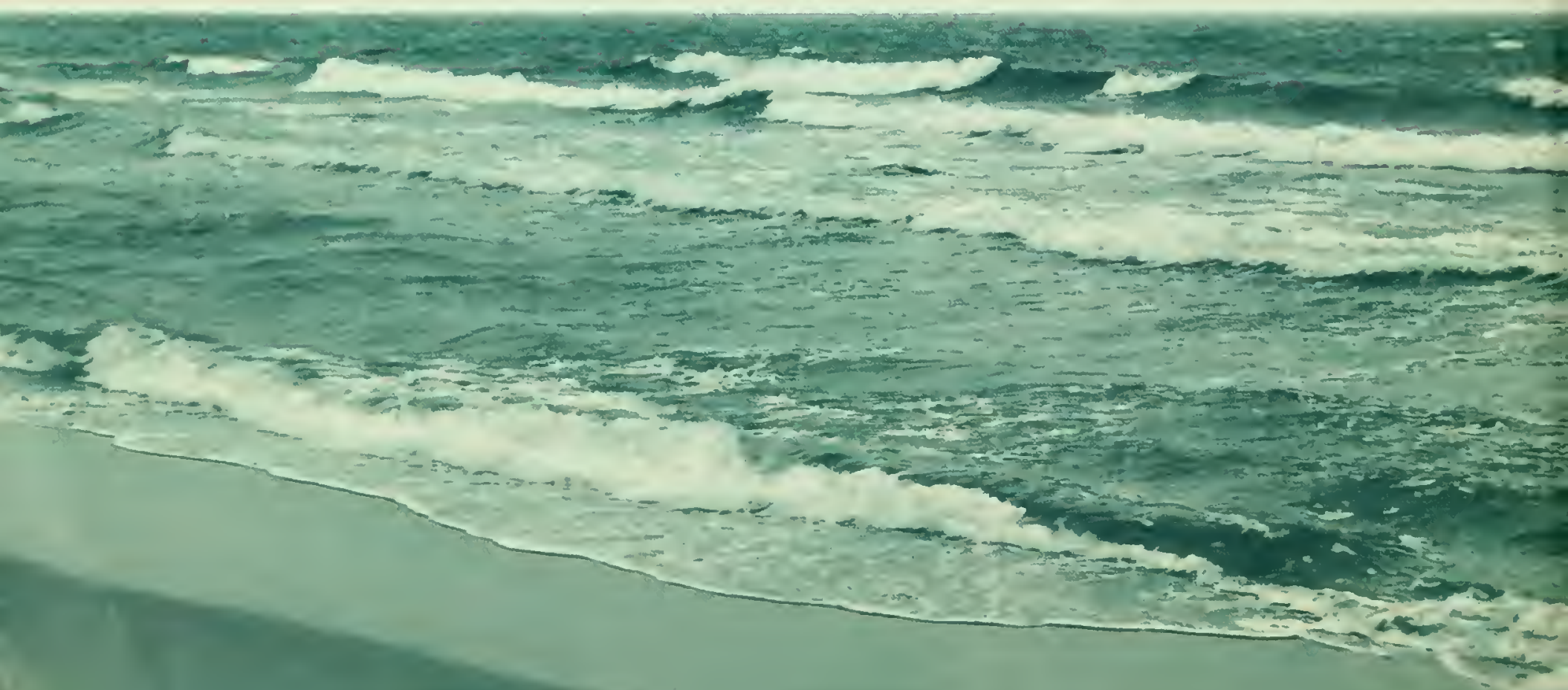




\section{THE FIRST NORTH AMERICAN}

FISHERIES CONFERENCE

\section{Canada $\cdot$ United States $\cdot$ Mexico}

WASHINGTON, D.C.
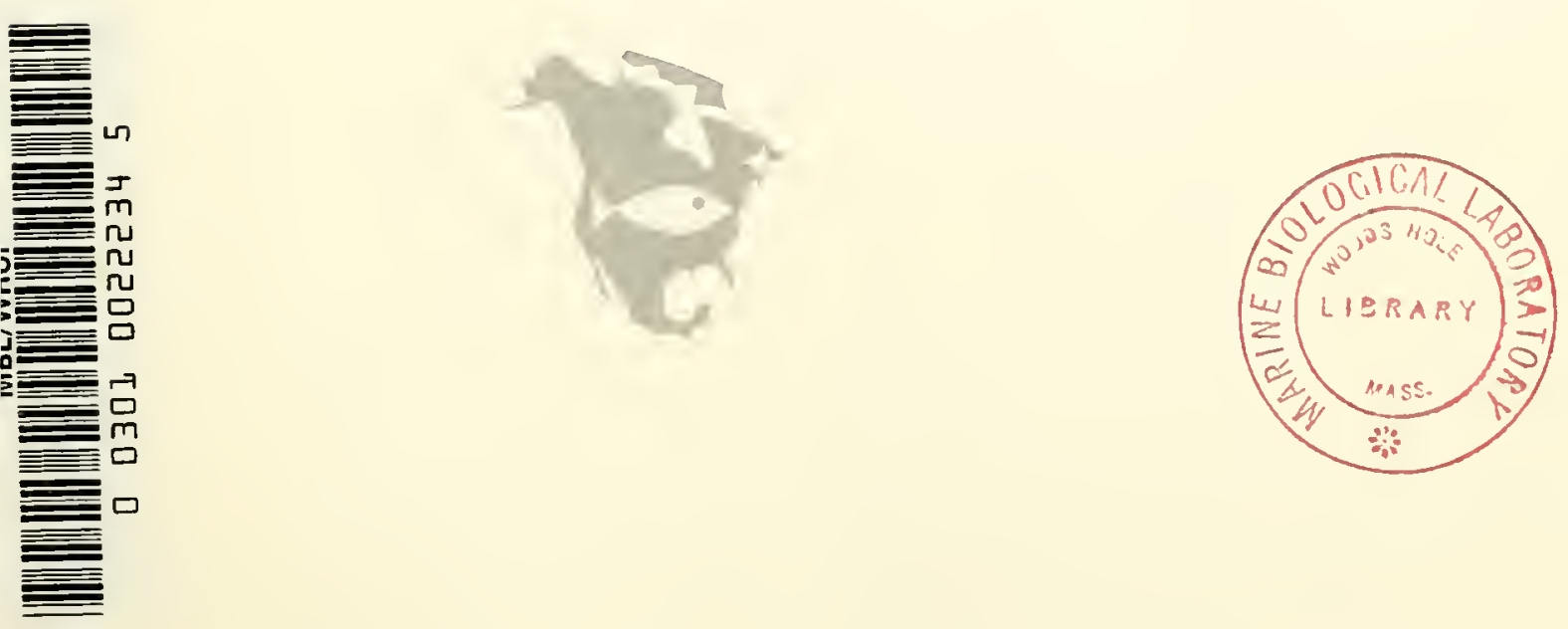
This publication consists of addresses and panel discussions at the Jorth American Fisheries Conference in Washington, D.C., April 30-May 5 , 1965. The Conference was sponsored by the National Fisheries Institute. Inc., Washington, D.C., the Fisheries Council of Canada, Ottawa, and Camera Nacional de la Industria Pesquera, Mexico, D.F. The material is in chronological order, as presented May 3-5.

For sale by the Superintendent of Documents, U.S. Government Printing Office Washington, D.C., 20402 - Price 65 cents 


\section{Contents}

North American Fishery Potential............. Peter A. Larkin

Are Our Fishery Resources Being Properly Developed and Managed?... . . . . . . . . . . . . . . . . . . John L. Kask

Politics and the Marine Fisheries........ Wilbert McL. Chapman

Oceanography and the Marine Fisheries........ Milner B. Schaefer

The Future of Fish Harvesting.............. Basil A. Parkes

Processing-Tomorrow............... E. Robert Kinney

A Panel Considers: "Sell Up To Higher Profits" ... . . . . . . . . .

Arthur H. Frohman, John Mehos, Eric S. Turnill, Wendell Earle, and Murray Wheeler

All the World's a Market................. Mitchell Sharp

World Demand Complicates Conservation........ H. J. Robichaud Mexico's Fishing Industry............. Lic Jorge Echaniz R. 52

World Markets and Demands.............. Stewart L. Udall

Role of FAO in World Fisheries

Roy I. Jackson

Summary of Conference: The Future of North American Fisheries. . 


\title{
North American Fishery Potential
}

\author{
by P. A. Larkin \\ Director, Biological Station \\ Nanaimo, British Columbia \\ Fisheries Research Board of Cunada
}

The North American fishery potential may be appraised in various ways, which vary in the degree to which they take cognizance of the biological, economic and political facts of life. At one extreme, an unihibited enthusiast can describe a cornucopia of immense proportions, while at the other extreme a pessimist may see less potential than we currently exploit. Pcrhaps then it is most appropriate to paint a variety of pictures, so that to some degree we may be able to assess the various alternatives that might lic ahead.

A current and fundamental approach, summarized with effectiveness by Schacfer in 1964 and Chapman in 1965, begins with the observation that the occan covers about three-quarters of the world's surface and receives, therefore, a like fraction of the sun's energy. With appropriate calculations it ensues that each year the world's oceans produce 19 billion tons of living plant mattcr-mostly in the form of very small, singlecelled plants. This production, to be put in proper perspective, should be placed with our resources of pine needles, grass, and autumn leaves and such, as a last-resort source of food should we ever face the dire necessity. In general, this primary production in the sea (in contrast to plant production on land) is not in a form suitable for efficient harvesting by man, and requires concentration by small herbivorous animals. These plankton organisms, perhaps produced at a rate of more than 5 billion tons per year, are similarly dispersed widely in the 329 million cubic miles of the world's oceans. Again, then, to put most of this production in perspective, it should be added to the comparable resources on land, not to the cows and other big herbivores, but to the beetles, caterpillars, earthworms and such-which are not at present harvested in most places for various reasons of taste and economics. Even assuming we would like plankton if we were served it, there is grave doubt that the calories we got out of it would equal the calories we put into getting it.

Some of these herbivores, such as shellfish, shrimp and small species of fish such as anchovies, are major crops from the sea, with enormous potential, but still another level of concentration is usually neccssary before the vast production of the world's oceans is in a form suitable for man. This concentration is made by the predators of the occan many species of fish ranging from snappers to salmon, bonito to barracuda: many species of squid, whales, and their relatives, and the similar larger animals which comprise most of man's prescnt harvest from the sea.

We now, then, may construct a more meaningful picture. In this vast watery factory that converts sunshine into food, what is the potential annual production at the level at which man (as an animal) seems likely to operate? The answer appears to be somewhere between 1 and 2 billion tons, which converted into protein foods is more than adequate for ten times the world's present population of 3 billion people (Chapman, 1965).

The next obvious question is - "will this amount, combined with the production on land, be enough?"-- for what will the world's population be, when we bear in mind that there are some things you can't make unpopular? It has been argued that man is a social animal and his population will be regulated by social forces; to think otherwise is to ignore both evolution and history. World population for various reasons might, we are told, level off at 30 billion, also roughly 10 times the present population. Accordingly, to bring this assessment to a conclusion, we surmise that the world's oceans could suffice if called upon to save mankind from a global famine.

It is of interest in passing to note that the present world catch approximates 50 million metric tons, certainly less than onetenth of the potential catch and perhaps as little as one-fortieth. Similarly, I presume, there are opportunities for very much greater production of human food on the land masses of the world.

These speculations are important to philosophers and to those of us who will live into the 21st century, but for the purposes of our present conference it's perhaps better to come to closer grips, to ask the question: What is the potential on the coasts of North America for developing fisheries of the kind that men have developed and are developing in various parts of the world?

As a continent, North America is no different from most, oceanographically speaking. It has endowments, coast for coast, which compare reasonably favorably with the other continents. Patterns of oceanic circulation, areas of continental shelf, factors of climate and weather, characteristics of the sea 
bottom and other factors are variable, but average in no conspicuous way as any more or less favorable than those of other continents taken as a whole. The character and diversity of our marine life is adequate for conversion of these physical attributes into "fish-flesh." Thus, there is no biological reason why production along our coasts should not be roughly equal to that of comparable stretches of coastline in other continents. Ignoring all unproductive polar regions, our coastlines are about $20 \%$ of the world's total. Marine production from regions of our coast is about $9 \%$ of the world's total. Evidently, the gross potential for kinds of fish which can be used by man today is at least twice what is now caught off our shores. With this doubling, the catch would still be only at the average world rate, and much greater catches are possible with an intensification to the higher rates of utilization in the more developed fisheries of the world. The North American coastal fisheries are apparently amongst the "developing fisheries" of the world.

Where is this potential? What is not now being caught that could be turned to as a basis for immediate increases in catch off our shores? Several recent publications summarize potentials region by region, and this is perhaps not the time and place to summarize the local statistics. Of real interest are the trends which seem to be suggested around all shores of the continent.

First, the offshore fisheries for demersal species are capable of greatly increased production. On both Atlantic and Pacific coasts various species of groundfish are currently being exploited in quantity for the first time-and as we all know, largely by other countries. For example, in the ICNAF area, the Northwest Atlantic, there was a catch in 1963 of 2.8 million tons, of which only about one million was taken by Canada and the United States. There seems every prospect that the annual catch from the area can be further increased by harder fishing of the species now taken and by further diversification into species not now utilized (Martin, 1963).

A similar demonstration of North American groundfish potentials is available on the Pacific coast. In 1961, the catch of groundfish in the Bering Sea by the USSR and Japan approximated 850,000 tons, and included just about one-half of the world's catch of flatfish for that year. By contrast, Canadian and United States production from the Bering Sea grounds was confined to the harvest of less than 3,000 tons of halibut. In recent years, also, the Bering Sea and the Gulf of Alaska have produced substantial quantities of ocean perch, enough to account for from 10 to $30 \%$ of the world production of redfish (rockfish). This catch in the past vear was made perhaps nine-tenths by countries other than Canada and the United States. And, as in the case of the Atlantic fisheries, there secm many more opportunities for expanding catches of these and other species of ground fish.

Second, the pelagic and midwater fisheries seem capable of much greater expansion off North American shores. Although herring and their relatives already account for $30 \%$ of North American production, their catch could be greatly increased off almost all of our coasts. The anchovies of California, threadfins in the Gulf of Mexico, the herrings of Alaska and the herring, capelin, argentine and sandlance of the Canadian east coast have all been mentioned recently as attractive opportunities. Similarly there appear to be large quantities of hake on both cast and west coasts that await exploitation, particularly perhaps by midwater trawls.

Third, there are many opportunities for increased catches of crustaceans, molluscs and other bottom-dwelling invertebrates. Many shrimp and mollusc potentials remain unexploited, and a great variety of species which are used in some parts of the world are still untouched along most of our shores.

Fourth, as the overall rate of fishing intensifies, the rate of catch of some of the favored species declines, and their average size also declines. With progressively smaller catches of smaller-sized fish, the economic return diminishes, even though biologically the species may be capable of supporting an even greater maximum sustained yield. As fisheries biologists have begun to realize, considerations of maximum sustained yield decide how much can be caught, but considerations of maximum economic yield decide how much is caught, and who catches it. In consequence of the competition, some fishermen (perhaps largely from some countries) drop out of the race, and turn instead to other species for which a market can be created. Potential can thus be measured only within the context of international competition. Whoever is most efficient has the greatest potential.

The diversification of catch which arises from competition also carries in its train a number of biological consequences. The ocean is the world's oldest and most complex community of aninals. A complex weh of interrelationships relates each species, in one way or another, to almost every other species. It is as though, instead of selecting only one species of tree to harvest in the forest, we had begun to take some of each kind.

What this may do to the ultimate proportions of the various species is difficult to assess. Our ignorance is best illustrated by pointing out that at present we have no generally accepted theory for the effects of fishing on any given pair of species that may be related as predator and prey, or as competitors. Bcaring in mind that as many as several hundred species may be involved in such interrelations, we are on the threshold of some exciting new experiments in marine science as our fisheries develop.

From the viewpoint of potentials, it would seem likely that we should expect increases in total production but not necessarily from the species we have traditionally fished or are now fishing.

It would seem then from this brief appraisal that our offshore fisheries are capable of substantial expansion. A decade ago we might have been in doubt about some of these potentials. Today they are largely being demonstrated for us by others who, either fishing off our coasts or by their example off their own shores, are pioneering intensive cropping of a great diversity of marine animals. It is worth saying again-when it come to offshore fisheries, we of North America are amongst the "developing countries".

Our freshwater fisheries potential is very great compared to other continents, for with the Great Lakes and the large Canadian northern lakes we, together, own the biggest expanses of 
fresh water in the world. Although freshwater production is small compared to that of the oceans, it has the merits of being close to markets and easy to scll to traditional consumcrs. If you just add up the area of fresh water, you get the impression that there is a big potential, but of course this is misleading. A single pond in Alabama not only produces ten times the annual crop of a similar pond in the Yukon but is very much more likely to be fished. There are tens of thousands of lakes in Northern Canada, but each produces a small amount, and they are a long way from markets. To harvest fish from them is like picking berries when the bushes are a mile apart and there is one berry per bush.

The really large freshwater potential lies in better protection, better management, and the culturing of freshwater fish. An even bigger potential lies in the protection of seashore areas and their use for culturing of sea foods. In several parts of the world, where necessity has goaded invention, there have been developed techniques of artificial culture which have proven capable of greatly increasing production in fresh water, brackish watcr and salt water close to shore. For example, there are a number of demonstrated possibilities in oyster culture. Shrimp culture is already in production in some areas. The construction of artificial reefs may increase production of desirable species of fish by as much as twenty times. Freshwater pond culture for trout is an economic proposition in the right circumstances. Salmon hatcheries beckon with better documented promises, though admittedly we must restrain our optimism because for 50 years they have more often than not confounded the enthusiastic arithmetic which spawned them. Properly managed, reservoirs can be big fish producers. Up to 1959 , over 130,000 acres of man-made lakes had been constructed in the U.S., and much greater areas arc in prospect. Over and over, especially for those species for which there is the greatest demand, we are witnessing an accumulation of information which, combined with modern technology, implies a great potential. In many respects, investments in these enterprises may prove more rewarding than pouring funds into more sophisticated ways of hunting scarcer and scarcer fish in the common pastures of the world's oceans. The choice is quite akin to raising chickens, rather than buying radar and anti-aircraft guns to shoot ducks.

But of course one can't speak of the potentials of freshwatcr and nearshore sea-food culture without again sounding the warning of two generations of conservationists. Much of our network of freshwater drainage and portions of our sea coasts have at least for the present been rendered quite unsuitable for food culture of any kind. Domestic and industrial effluents have destroyed substantial production of sea foods in shallow bays and estuaries. Drainage and land reclamation schemes have converted potential fish cultural opportunities into marginal farm land and often dreary real estate. A great many of our rivers and lakes no longer produce a useful crop of any kind. Pollution abatement is not keeping pace with suburban development and industrial growth. It may well be that the next generations shall have to pay dearly for the freshwater fish they wish, in part because we didn't foresee their need. To learn the appropriate lesson we have only to look to other parts of the world, or the worst parts of this continent, which are just a few years ahead in terms of population congestion. For both food and the relaxations of angling, we will be raising fish; we can make it much easier by a little foresight.

To spcak of "fish that people wish" leads naturally into what is perhaps the most realistic appraisal of North American fishery potential. Essentially, the potential we have will depend on the nature of the demands for sea-food products. Although this sccms obvious cnough, it is surprising how often we forget it. For instance, there is no market and hence no potential in the fresh air business, even though there is a huge supply, much of which is going to waste, and much of which is being breathed by people we don't agree with. Similarly, although there are large quantities of fish in the ocean, perhaps more than mankind could ever use, they don't constitute a potential by the mere fact of their existence. They must be needed, and needed sufficiently more than other things, to make it a profitable venture (in the broadest sense of the words) to pursue them.

What I wish to say is this - to really appraise North American fishery potential, the place to start is with the consumer. There exists at present a substantial demand for fish foods. With shortages of other forms of food, if they materialize, there will be created a further demand for sea foods. Beyond this, there are demands which may be created by the marvels of modern advertising. These demands, from North Americans and people in other parts of the world, will determine what we consider as our potentials.

These demands will also determine what other countries consider as their potential. There is no valid reason for supposing that these other countries won't be realizing our potentials, both by catching fish off our shores and by selling in our markets, fish caught anywhere in the world. And, conversely, we can consider all the world's oceans as our potential supply for satisfying markets in all of the other continents.

Our North American fishery potential thus hinges not only on the supply of fish available, and on the demand for sea foods, but on the efficiency' with which we can catch them or raise them and the enterprise we use to sell them. The real potential is in the people throughout the fish business. I presume that Dr. Kask will pose some embarrassing questions about their competence, to which Dr. Chapman will provide all the answers.

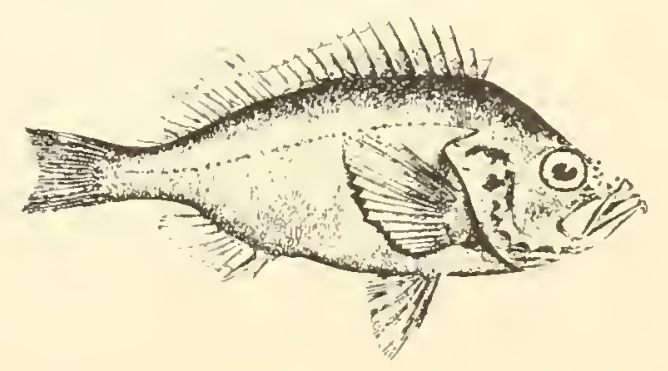


Anthony D. Scott, the Canadian economist, has summarized some of the findings and forecasts of the Fond and Agriculture Organization on food and gross national product and of the United Nations on population:

- The world population is growing about 1.75 percent per year and may double in 40 years.

Demand for food-fish is expected to rise $3-t$ percent per year for the next 10 years, and may double in 25 years or less. Increase in fish consumption would be greatest where population growth is fastest and present consumption per person is very low. In such areas, even a small increase in income per person can have a very large effect on demand for food-fish.

- Today, the Americas and Europe consume about 30 percent of all food-fish. In 10 years, their share may fall to 25 percent. Most of the increase in share would go to Asia. Africa, and the Sorict Union.

- If fishmeal and other nonfood uses are added to food-fish estimates, total increase would run $4-5.5$ percent per year.

This would compare with growth of total catch since the war of almost 6 percent per year. An increasing proportion of this postwar increase has gone to reduction plants. Peru, the world's leading fishing nation, has put almost all of her greatly: expanded catch into fishmeal

\section{GROWTH IN WORLD FISHERIES AS COMPARED WITH WORLD POPULATION INCREASE}

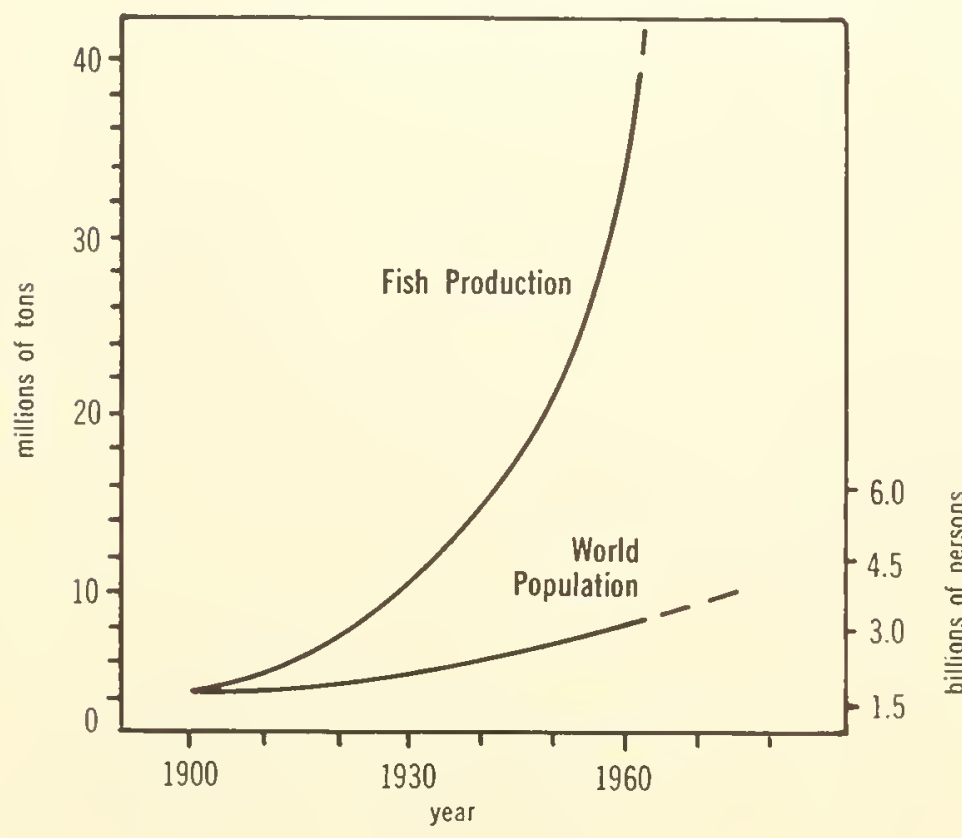

WORLD CATCH OF FISH AND SHELLFISH, ETC., BY LEADING COUNTRIES, 1955-65

\section{billion pounds}

live weight basis

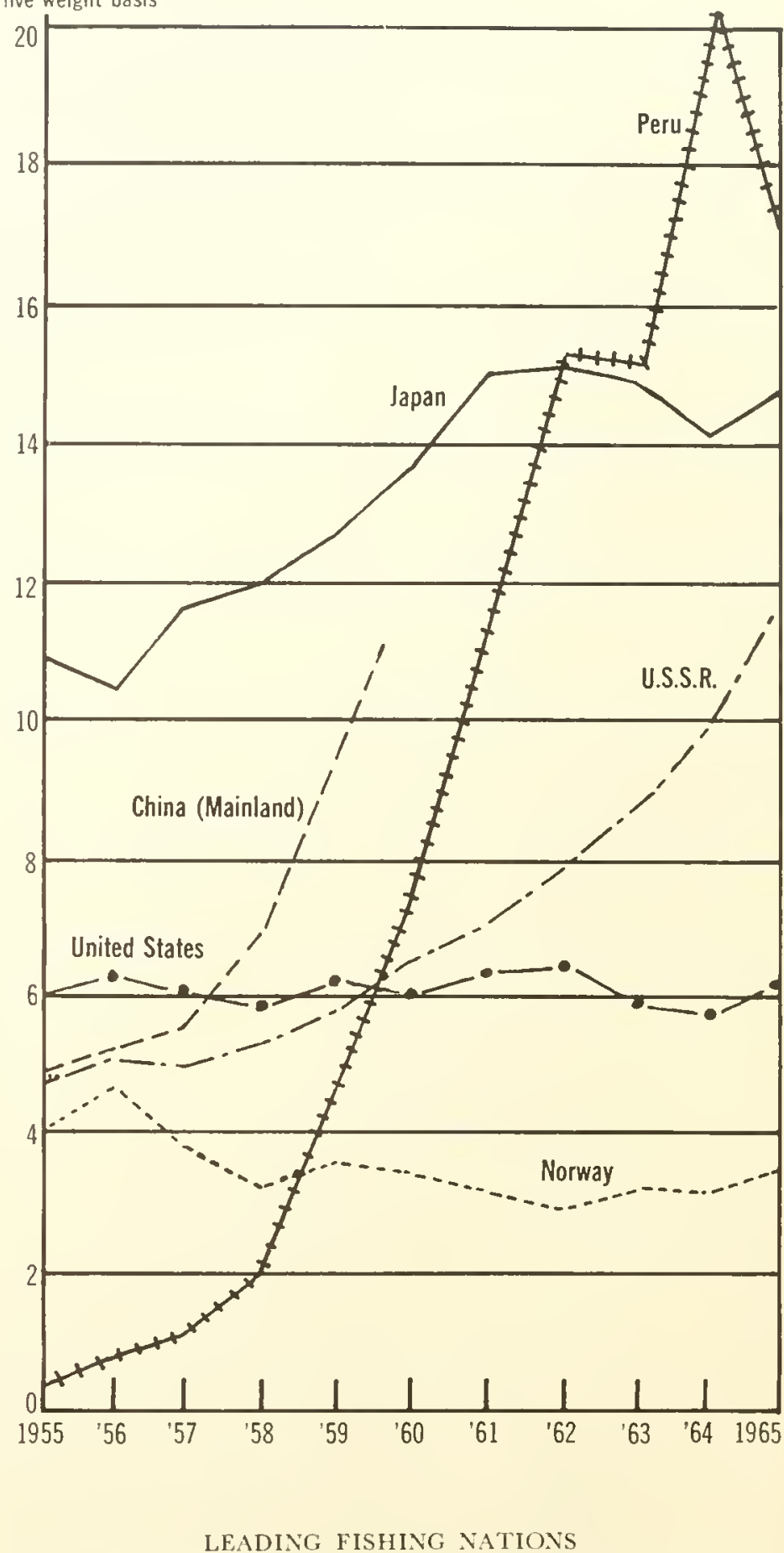

Until 1957, the United Statcs was second only to Japan in volume of catch of fishery products. Data submitted to the Food and Agriculture Organization of the United Nations by Mainland China for 1957 indicated that in that year it had moved into second place. In 1960. both Peru and the U.S.S.R. also moved ahead of the United States. 


\title{
Are Our Fishery Resources Being Properly Developed and Managed?
}

\author{
By J. L. Kask \\ Director of Investigations, Inter-American Tropical Tuna Commission \\ La Folla, Calif.
}

The assignment $\mathbb{I}$ have been given at this session is to ask the question: "Are our fishery resources being properly developed and managed?" I am assuming that the question is being asked of the three countries meeting together today. From this general question, I would like to develop four specific questions to pose to our third and final speaker. Two of my questions will be about resource development and two about resource management. Management and development together, in my definition, add up to resource administration.

By way of background to my first question, I would like to review the following thoughts.

I think it is pretty generally conceded that world fisheries have made more progress and have developed faster in the last 15 years than in all the rest of this ancient industry's long history. Technological advances in floating equipment, in methods of fish detection and capture, in preservation, and in distribution have made it easily possible to catch fish in any waters of the world and to deliver the product to any market in first-class condition. These developments have ushered in distant-water fishing by many countries and in all parts of the world ocean.

The total world catch in 1950, just 15 years ago, according to the FAO Fisheries Yearbook, was 20.8 million metric tons. The catch in 1963, according to the same authority, was 46.4 million metric tons, or more than twice as much. This is an increase of more than seven percent per year. In 1963, the fishermen of four countries caught nearly half of the total world catch, but no North American country was included among the four. In fact, 15 years ago, three of the four leading fishing countries of 1963 (the USSR, Mainland China and Peru) were not considered important fishing countries at all. So, revolutionary fishery developments are taking place.

In 1950 (again according to FAO) Canada, the USA and Mexico together caught 3.6 million metric tons of fishery products. In 1963, the same three countries caught 4.0 million metric tons, an increase of 0.4 million. An examination of these catches reveals that most of this modest increase for North America as a whole was made by Mexico, whose catch had increased slowly but steadily from 68,000 metric tons in 1950 to 244,000 metric tons in 1963. During this same period, Canada's catch varied from just above to just below one mil- lion metric tons, showing no positive increase, and the U.S. catch varied similarly, according to the availability of industrial fish, between 2.5 million and 3.0 million metric tons. Mexico, during this period, retained her relative position in the world picture but the USA was deposed from second place to fifth and Canada from fourth to seventh. As Mexico scems to have moved more in step with world developments, the question I propose to ask will apply principally to Canada and the USA.

With this background then my first question is: Why, when world fish production has more than doubled since 1950, have North American fish producers barely held their own, and this in spite of the fact that effective demand for fish products has continued to increase? The combined US and Canadian populations increased by 55 millions during this period. This represents a lot more fish eaters; and in 1963 the US imported more by a third ( 6.6 billion pounds) fishery products than her total domestic production, and three times Canada's total production. And as you have already heard, this isn't for want of available resources.

Now to lead up to my second question, which deals with another phase of development.

It is generally recognized by authorities in the field of nutrition that fish products are among the finest sources of animal protein in existence. Fish muscle contains all the "essential" amino acids required for complete nutrition, and body building. Fish liver oils contain needed fat-soluble vitamins and muscle fats are polyunsaturated and thus contain additional therapeutic qualities that are important in these day's of mass hypertension. Besides all this, sea food is highly prized for its flavor. A good sea food restaurant draws its clients from tens and even hundreds of miles and to get a seat at a good fish eating establishment requires both luck and patience. Fish also rates among the most economical of good animal proteins, and its relatively low price has remained surprisingly constant. According to the Bureau of Commercial Fisheries, the average price paid to fishermen for all fish products has remained between 7 and 8 cents per pound, since the end of World War II.

Despite all of these obvious advantages, the average annual per capita consumption of sea food has remained for all postwar years a little above $10 \mathrm{lbs}$, in the USA, and a little more 
in Canada. During this same period, the per capita consumption of the fishes principal competitors, such as red meat, poultry, eggs and cheese has increased many times. So my question is :

Why, with such a good, economical and desirable food product to market, and with all our technological advancements in production, distribution and packaging, why is it that per capita consumption of fish has not at least kept pace with its market competitors? What is the matter with our fish salesmen?

And now my third question. This has to do with fisheries management and administration.

In the United States, the primary responsibility for fishery administration and management rests with the states. All 50 states have fishery departments or services of one kind or another, but maritime states, such as Massachusetts, Louisiana, California, Washington and Alaska, usually have these scrvices the most highly organized.

Federally, in the United States, the Fish and Wildlife Serrice and its Bureau of Commercial Fisheries have both research

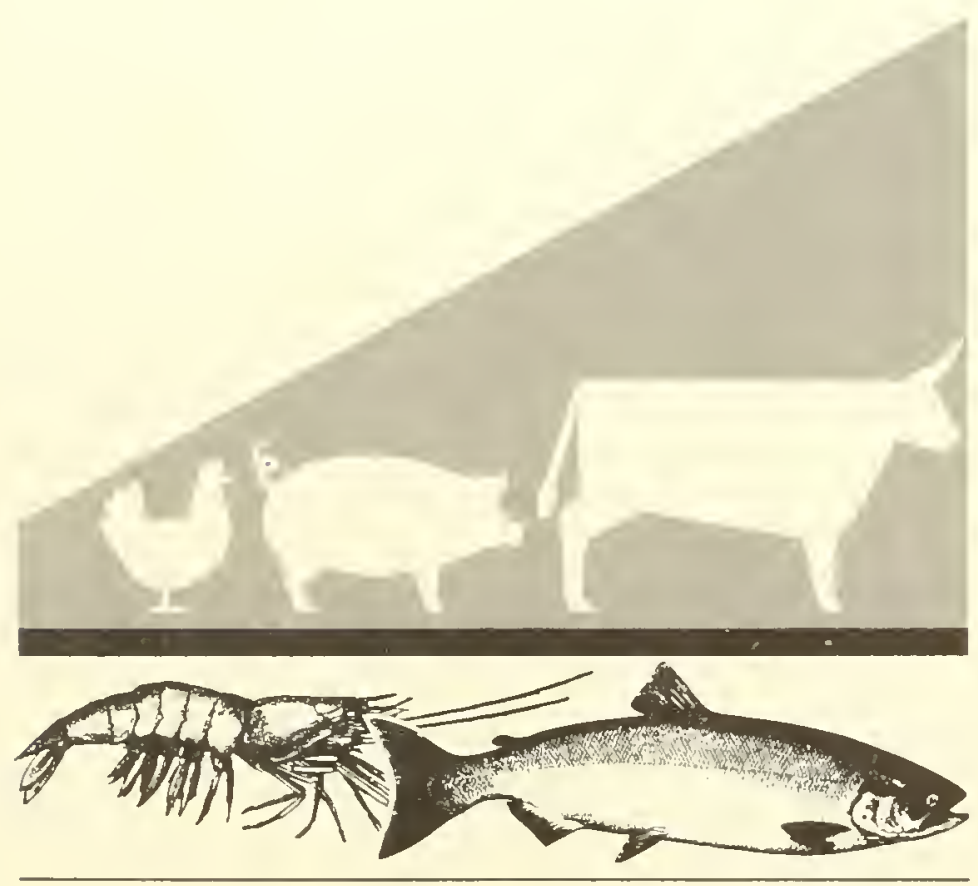

and development responsibilities. The Burcau of Commercial Fisheries used to administer the large and complex Alaska fisheries, but since Alaska became a state the Bureau's operational responsibilities in this field have been reduced.

In Canada, all 10 provinces have fishery departments or fisheries services, but the principal responsibility here, except in the province of Quebec and some inland fisheries, rests with the Federal Fisheries Ministry.

In addition, there are several international fisheries commissions which study and help with the management of some North Imerican fisheries. Some of these commissions have research staffs of their own and all have administrative staffs.
New commissions come into being when new problems of international concern arise. Four new conventions have been negotiated and commisions created since the end of World $\mathrm{W}$ ar II. Canada is party to six such commissions and the USA to seven currently operational.

The point I am trying to make here is that our rather static North American fisheries appear to be pretty thoroughly administered and managed. With 50 states, 10 provinces, two federal governments and at lcast six international commiscions all having a hand in the job, it might be expected that this job is very thoroughly done.

And then there is the cost of these services. I have not taken the time to look into this aspect very thoroughly, but costs have grown very substantially since 1950, even though the fisheries have not. Washington, a typical sea coast state, had a biennium appropriation of 6.7 million dollars for 1963 65 , which is about $3 \mathrm{y} / 4$ million dollars a year. This, of course, is the cost for only one state government, but I am sure it is not the largest.

The fisheries part of the old Fish and Wildlife Service, that is the part roughly comparable to the present Bureau of Commercial Fisheries, had a budget of about five million dollars in 1950. The appropriation for 1965 of the Bureau of Commercial Fisheries is 27.4 million dollars.

In Canada, the Federal Fisheries Ministry, which includes the budget for the Fisheries Research Board of Canada as well as Canada's share of the international commissions (in the U.S., intemational commissions costs are found in the Department of State) had nine million in 1950. In 1963 , it was very nearly 26 million.

The cost of the six international commissions to which Canada and the U.S. are both party approached 3 million dollars in 1963. About onc-half of this latter amount however is used to kill lampreys in the Great Lakes.

On the basis of the above, this is the third question I would like to pose: Is it possible that our fisheries are overadministered and overmanaged? Are there too many units in government dealing with this problem, thus absolving any one segment from responsibility for the management and development of this complex industry? And are the mounting costs of these services under the more or less static development situation really justified?

I should quickly point out here that I do not consider the amounts of money quoted as being too great for the progressive and planned development of such a complex industry as wisely harvesting and managing the internationally owned living resources of the sea. In fact, I think the amounts are pitifully small to carry out a competent and effective jo.s. My real question here is: Are we doing the right things with the steadily increasing amounts of money we are spending?

And now to my fourth and last question. This has to do with fisheries research. The costs of fisheries research are included in the totals for fisheries management and administration given above, but it may prove useful to look at this part of management separately, and I am going to limit this query to federal fisheries research, which has proven to be the best supported and the most productive. 
Certainly, fisheries research costs have risen proportionately with general administrative costs, and whencier a dynamic research director has been in charge costs have risen even more quickly.

In Canada, the costs of research are easy to separate out because the Fisheries Research Board operates under a separate budget which must be defended before parliamentary committees on its own merits. This is not quite as easy to do in the Bureau of Commercial Fisheries budget, but approximations can readily be arrived at.

That the quality and quantity of fisheries research in North Amcrica compares favorably with that carried out any place else in the world I think is not an exaggeration, and I think that North American fisheries scientists produce a very good unit return of research results for the dollars expended. It is the use that is made of research results by the pcople that pay for the research that prompts my next question. Are our domestic fisheries really profiting fully from our research results or are we in fact doing our good research for the more dynamic fishing countries?

The budget for the Fisheries Research Board of Canada for fiscal $1950 / 51$ was 1.5 million dollars. For 1963/64, it was 5.6 million dollars, or nearly four times as much. I do not have the breakdown for the 1950 fishery research budget of the old Fish and Wildlife Service, but one-third of the five million dollar total should not be far off. In 1965, the amount appropriated for the management and investigation of resources for the Bureau of Commercial Fisheries totalled 19.1 million. These ever-mounting costs for national research programs, especially that part dealing with the high-seas resources fished by more than one country, leads me to my fourth and last question.

If, as it appears, that constantly expanding national research programs do not insure progress and development in our fisheries, should we continue these national research programs at the present and ever-increasing level, or would it be better to have international resources in international waters studied and managed by international staffs of scientists working for international bodies, where support for the research and management is prorated on the amount of the resources harvested? Whenever we have tried this formula, it has proven quite successful.

In quick review then. As fisheries administration and management costs per pound of tish harvested in North America has increased many times in the last decade and a half, my four subquestions under the general question "Are our fishery resources being properly developed and managed?" are: If they are properly developed and managed then-

(1) Why have North American fisheries not developed at least at the same rate as in many other important fishing countries of the world? Or at least kept up with effective demand?

(2) Why has per capita fish consumption remained constant for decades when competing products have constantly gained consumer favor?

(3) Are our fisheries perhaps being overmanaged and administered, and by too many units of government, thus not pinpointing responsibilities for management and development?

(4) Can high and increasing costs of national research programs on international resources in international waters continue to be justified in the face of lagging development?

Before I sit down (or get knocked down) I should quickly: point out the obvious truth that it is much easier to ask these questions than to provide acceptable answers. I have been trying to answer these same questions during a lifetime in fisheries research and administration, in both Canada and the United States, without any obvious signs of success. The questions I have raised however are in my view pertinent and should be answered if our fisheries are to get out of the doldrums and begin a healthy growth. I think it is obvious that somc stimulus or stimuli other than those currently prescribed are indicated. If Dr. W. M. Chapman, the man you have asked to answer your and my questions, cannot answer them, then I do not know who can, since as a very good fish doctor he has spent a lifetime diagnosing troubles in our business and prescribing cures; and with a large measure of success at that.

Thank you. 


\title{
Politics and the Marine Fisheries
}

\author{
Wilbert McLeod Chapman \\ Director, Division of Resources \\ Van Camp Sca Food Company \\ San Diego, Califormia
}

We have been examining this morning the future of North American fisheries. Presumably this means the future catch of fish by North Americans in the ocean bounding North America.

Dr. Larkin has given us some appreciation of what ocean resources are available in these waters upon which such an expansion can be based. Dr. Kask has described for us the managencnt problems we presently have, and which may be anticipated in the near future. This afternoon Dr. Schaefer will give us a closcly related part of this subject in his treatment of oceanography and the marine fisherics. Also Messrs. Corny, Parkes, and Kinney will describe for us what is going on in advancing the technology of harvesting and processing of fish that will affect this future. Others, at a later time, will speak on the marketing aspects.

The very organization of this series of talks on the full range of fishery problems under the auspices of the fishery trade organization of our three neighboring countries is an encouraging sign. Perhaps our industries are approaching that stage of maturity where we will no longer be the ignorant hunters of wild things in the deep, but will be so organized that integrated industries will use the results of operations research to search out, harvest and rationally manage ocean resources-to the end that cost per ton of production will be minimized. These integrated industrials will also process, distribute and market the products in such a manner that the consumer will have an cver-growing volume and variety of sea products available in desirable form at as low a cost as possible. One hopes that we are heading rapidly in the direction of applying the findings of science and teclnology to all of these things in a framework of rational social, economic, political and diplomatic thought and activity.

The practical situation, however, is that the fishing industries of our three countries are far from this condition at present. The Mexican industry is now beginning to get into the modern stride of ocean resource development other than shrimp. Large scctors of the Lnited States industry, however, have been stagnant for a decade or more and show few signs of livening up. I belicve our Canadian colleagues will agree that their domestic fisheries are not developing as rapidly as might be desired.

Our latent resources are rich. Fishemen from Europe and Asia come thousands of miles from their home ports to harvest them regularly and in increasing strength and variety. We of this continent are particularly noted in the world for our industrial, managerial and scientific skills and the application of these factors to the improvement of human activity in most walks of life. But we have shown very little aptitude during this century of science and its application in competing with the countries of Europe and Asia in the full use of the living resources of the sea.

I wish to examine this morning some institutional reasons that may be contributing to this condition. The technical term institutional problenss used in this fashion simply means barriers that we put in our own way to prevent ourselves from doing what we want to do. They arise ordinarily from economic and social rcasons and conflicts and are adopted mostly through political means. For the most part, they are also remorable by political means, and by those means alone. Accordingly, I have entitled my talk "Politics and the Marine Fisheries".

When I speak of politics, however, I am not talking only about elective officials and their doings. I am speaking more broadly of human relations and the means whereby people get along with each other inside companies, in trade associations, in communitics, and with other groups of people everywhere.

I shall deal mostly with situations of this sort in my own country, and in my own State of California. This is for two reasons. In the first place, I know more about these problems close to home. In the second place, political matters are generally somewhat sensitive to talk about publicly and I will step on fewer tender toes as I confine my remarks to home grounds. Nevertheless, something of what I say may have broader application.

\section{Competition With Other Foods}

The ocean produces as human food mostly animal proteins and oils, and it can produce more of these things than are needed by all mankind at present population levels, and at considerably higher population levels as well. The land also produces animal protein and oils, and vegetable proteins, oils and carbohydrates as well in great abundance. 
It is possible that the unsaturated oils of fish have special health benefits in the human diet by affecting beneficially the cholesterol level in the blood and mitigating the occurrence of heart disease, strokes, etc. However that may be, the Federal Trade Commission will not let us say so in advertising. There are other pharmaceutical attributes that fish protein and oil may have that make them particularly valuable in the human diet. In rare instances do we know enough about such purported attributes to be permitted to advertise those facts under United States law. Accordingly, we must sell fish as food and not as medicine.

Some kinds of fish have particular taste attributes, but by and large the present American palate likes bland tastes so that this is seldon a prime sales factor. Too often the fish taste is equated with age of product before processing. As a general rule, if a fish tastes or smells fishy it has already begun to spoil. and nobody knows this better than the consumer. Unprocessed fish from the sea takes more trouble to prepare for eating than meat, and tends to create undesirable odors in the house while cooking. Under current social conditions in the United States, these attributes are marketing handicaps. Fish generally spoils more quickly than meat and is much more sensitive to damage in transport. Thus it must bear extra costs in careful handling at all stages from the ocean to consumer, and of careful preservation and processing at all these stages. Thus it must start on its way at as cheap a cost per ton of production as can be arranged, if it is going to compete with other foods on the final consumer market.

Having spent much of the decade of the 1950 's seeking protection for fishery products from international competition on this market, 1 am under no illusion on that score. In my lifetime I do not expect to see additional protective tariffs or quotas adopted for fishery products in this country and, instead, expect to see those that exist continually under presure for reduction.

Similarly, I do not expect to see the Congress provide direct subsidies for fish production. It was saddled with all sorts of subsidies for agricultural products a generation ago, which created a monstrous maze out of which it is still trying to grope its way. The sorts of subsidies which the Congress will be prepared to provide are indirect means aimed at helping the industry help itself, through education, ocean research, economic and technological research, vessel design, and even the construction of new sorts of vessels which might lead the way to improvements.

The hard fact is that fish in this country competes in a rough consumer market for food and it can expect no help from the outside. It must appear on that market in more desirable form and at cheaper cost than other competitive food products-not only to increase in volume of sale, but to hold its own. Most of my comments will be directed to this cost factor.

\section{State Laws}

The regulation of fishing in the United States, aside from that done under treaty with other countries, is done under state laws. There is a growing conviction among students of this subject that a major factor preventing the rational expansion of the sea fisheries of this country is the maze of regu-

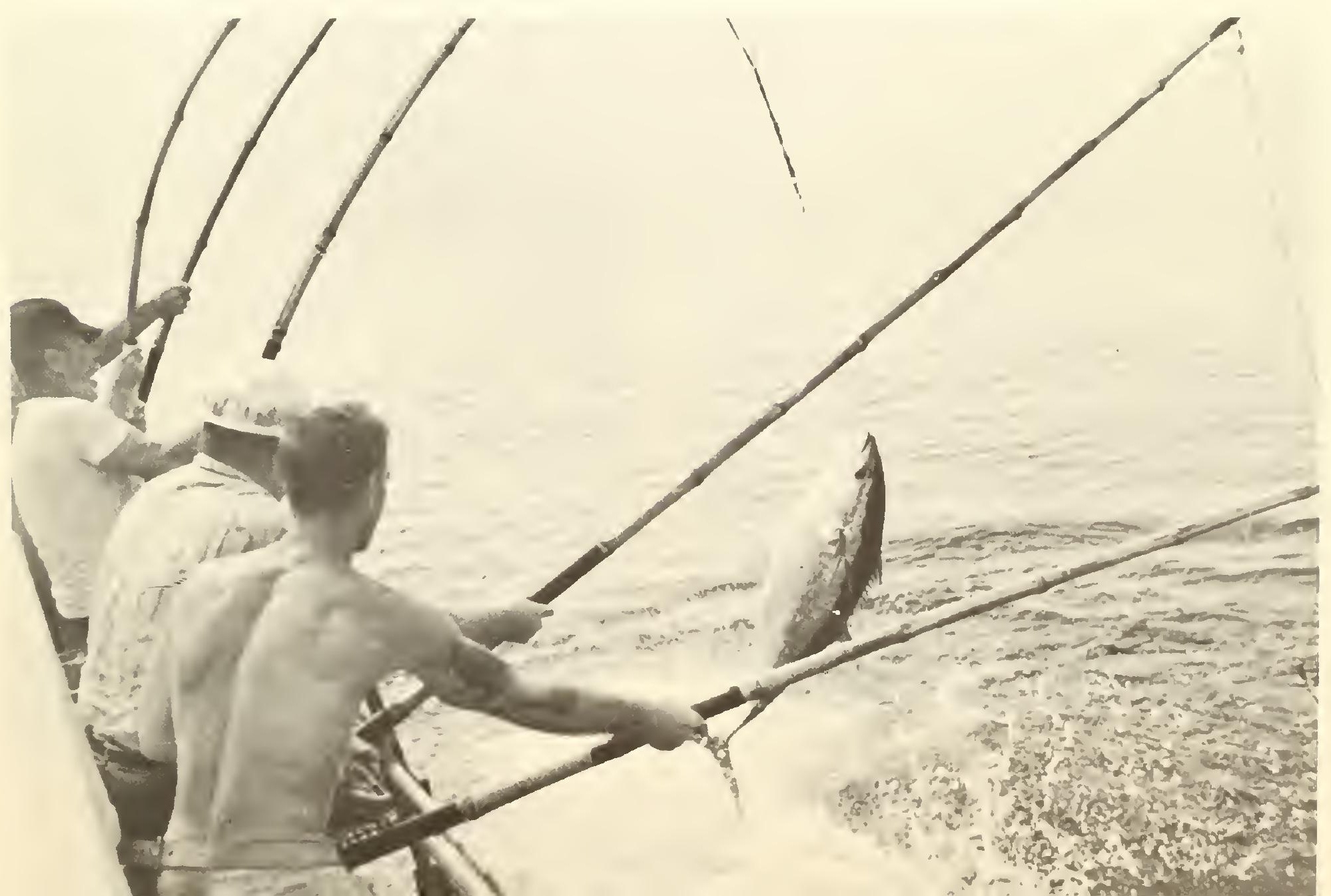


lations existing at the state level, many of which have their origins veiled in the mists of history but are still effective.

In my State of California, for instance, these cxamples exist:

One cannot harvest abalones commercially in Northern California, although they are abundant there.

One may not have a trawl net aboard one's vessel south of the border between Santa Barbara and Ventura counties, although trawl fishing is permitted off central and northern California.

One may not reduce fish to meal and oil without a permit from the Fish and Game Commission, which will not give one. There is no way under existing law for the California Department of Fish and Game to manage the taking of fish under modern conservation methods, establishing crop limits designed under scientific critcria to provide the maxinum sustainable yield; each casc must go to the legislature. In Alaska none may catch salmon with a purse seine vessel more than $50 \mathrm{ft}$. long. In Washington none may use electronic fish finders with which to locate salmon. In Alaska and Washington fish traps and other fixed gear have been eliminated. They were too efficient. In the North Pacific an American may not fish for halibut by trawl, or salmon on the high seas by gill net.

This is only the small beginning of a tabulation of the prohibitions against efficient fishing in the laws of the west coast states. Those for the Gulf and Atlantic states are not less forbidding, complex, or archaic. Propriety forbids me mentioning the welter of laws applicable in Chesapeake Bay, where the fishermen have been protecting their livelihood against the activitics of thcir more industrious or efficient colleagues by legislative means since before the United States Congress first met.

This problem is so complex and difficult that it is not possible to attack it rationally to find out what its effect on the nation's fisheries is without extensive legal, economic, social and resource rescarch on the state level. One of the principal purposes of S.J. Res. 29, introduced by Senator Magnuson for himself and others, is to provide the research base simply for examining the dimensions of this problem.

\section{Sportsmen Versus Commercials}

A prime generator of the above-noted welter of state law and regulations preventing the efficient development of the nation's fisheries is the continual wrangling between sportsmen and commercial fishermen over which one should be able to catch the fish exclusively.

In a lifetime of work in fisheries, my olsservations on this subject can only be blunt. A very large part of this wrangling has given the appearance of having been stimulated by professional sportsmen and professional representatives of commercial fishermen who desired the job insurance of such fights going on continuously so that they could earn retainers for appearing before legislatures. Another big part of this wrangling has been stimulated by gear fights among commercial fishermen where a group using one type of gear would team up with the professional sportsmen to legislatively prohibit the use of the other type of gear by their colleagues. All of you are familiar with such examples and I do not desire to rake

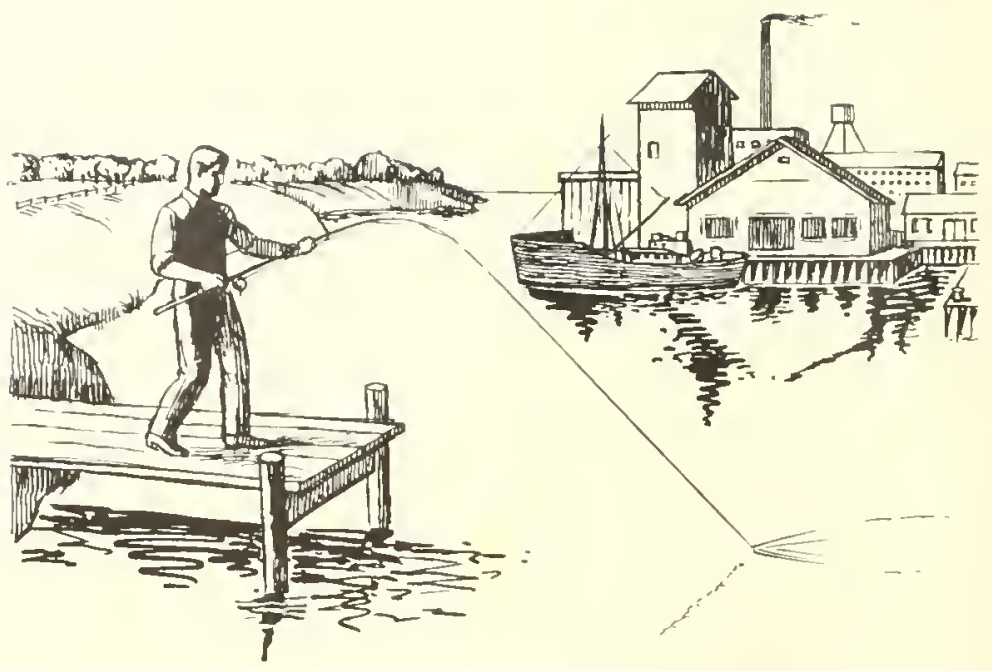

over old coals. Other causes of this wrangling just as ridiculous and selfish will occur to each of you from your own experience.

There remain, however, large areas of quite valid conflict between recreation and food industries respecting the utilization of ocean resources. Whether the food fish industry likes it or not, the recreation industry is here to stay and vice versa. There is no use in these two elements of the economy fighting with a view to knocking each other out. The areas of valid conflict are where there is a limited volume of a particular stock of fish that can be taken without the stock being overfished. Then priorities for catch require to be established.

Just how this may turn out in other states I do not know, but in California some progress is being made in looking into this problem in depth under the State Planning Commission. Here it looks as if there are only about a dozen species of fish of any volume importance involved in these quarrels. On preliminary examination, I am satisfied that a cold examination of the facts will result in satisfactory accommodations being reached on one of these species after the other and, finally, in respect of the whole lot.

Even this level of inquiry and action does not seem to be required to settle many of those squabbles. The salmon of northern California provide an example. For many years these fish generated the most bitter squabbles in the state legislature between the sports and the commercials. Some years ago, both sides discovered that while they were fighting over the catch it was such things as dams, irrigation diversions, and other river works inland that were causing the damage. Upon discovering this, they began to work together to save the salmon. Out of the research that developed it became plain that with each sportsman fishing for salmon on the sca able to take a daily quota that satisfied his recreational desires, there were enough salmon left over to support a substantial commercial fishery plus a spawning escapement sufficient to keep the stock in good condition.

In such instances, it seems logical that there should be cstablished an oserall quota which can be taken from the stock each year while still allowing adequate spawning escapement. In- 
side that overall quota should be established a reasonable individual daily bag limit for sportsmen adequate to satisfy the recreational purpose. The totality of these daily sportsmen's bag limit catches should be subtracted from the orerall quota needed for the protection of the fish stock, and the food fishery permitted to take the rest. The recreation use should have the priority:

A very considerable number of such wrangles arise simply through ignorance. A classic example is provided by kelp bass near Los Angeles. Sportsmen claimed that the cutting of kelp commercially was ruining their catch of kelp bass. Finally the University of California, as an impartial entity, was requested to inquire into the problem. Two beds of kelp in the vicinity, both heavily fished, were chosen for experiment. One was subjected to nomal commercial cutting; the other left uncut. Sport fishing for kelp bass continued normally and records of catch from both beds were kept. It turned out that sportsmen caught more kelp bass from the bed being cut than from the uncut bed. That controversy subsided.

\section{Inefficient and Efficient Fishermen}

A very large part of those sections of state laws inhibiting the growth of the marine fisheries in the United States arose from gear fights among commercial fishermen with or without professional sportsmen helping one side. These battles are often waged under the virtuous banner of conservation but the naked fact always revealed, when that banner is torn aside, is that the fighting cause is competitive economics. It runs like this.

One group of fishermen is working with gear or vessels that enable them to scratch out a living, putting by a few dollars in a good season, and going back into debt with the suppliers in a bad season. They are poor and they rather glory in their honest poverty and the homely virtues attendant thereto. They complain about the iniquities visited upon them by the rest of society, but they do not really want any change.

Then another fisherman develops a new idea, or science yields an instrument that will improve the efficiency of the catch and lower costs, or the Congress wishes to move things along by rewarding initiative in the introduction of new ressel designs or ideas. Historically, on the west coast, the fight also has been initiated when overfishing resulted in requiring the total fishing effort to be reduced. Then the most efficient gear had to go, making way for the less efficient but more numerous gear to still operate.

The bulk of the fishermen do not wish to change to new, more efficient ideas. They would rather stay poor, inefficient but, as they often say, independent. What they really want to do is keep the competition down or to eliminate it. Since they are more numerous, can be very vociferous, and have the virtue of honest poverty on their side, they nearly always win in the state legislatures where the principal fishing regulations of the nation are established. This was how the fish wheels and horse seines disappeared from the Columbia River, how the salmon traps disappeared from Washington and then Alaska, how it happened that one cannot land halibut caught by trawl in a port of the United States, why one cannot have a trawl net aboard one's boat in southern California, why one cannot use a sonar on a purse seiner to locate salmon in Puget Sound, etc., etc.

This classic opposition to change had been epitomized in the attempts made over the last several years by the Congress to improve the lot of U'nited States fishermen by providing them with improved vessels and vessel designs with federal assistance. Senator Magnuson at first tried to encourage the federal development of an experimental modern trawler for his people in the northwest to use in competition with the Russian and Japanese effort that he elearly saw approaching. His fishermen constituents refused to support him. He then tried to enlist support from New England where European fishermen were similarly approaching the New England grounds with modern ressels and gear. This gambit was repulsed by the fishermen. The fishermen, almost to a man, preferred to ask for the foreign fishermen to be outlawed from the fishery on the high seas (an action beyond the ability of the United States Senate to perform) and complain at the Senate and Department of State for not doing this, rather than to accept new ideas and assistance so that they could become sufficiently efficient to compete on the high seas with these foreign fishermen.

When the Senate desired to remove by direct subsidy the serious block of high priced fishing vessels which federal law supporting shipyards caused in the United States, the major fishing vessel owners' associations in the country were opposed. Finally, after six years, a reasonably workable bill on this subject was adopted by the Congress last session over this opposition, but still encumbered with safeguards insisted upon by the ressel owners to prevent them from being made efficient.

The ressel owners did not, and do not, want efficient new vessels and gear brought into their fishery. If this happens,

NUMBER OF U.S. FISHING CRAFT, VARIOUS YEARS, 1930-64

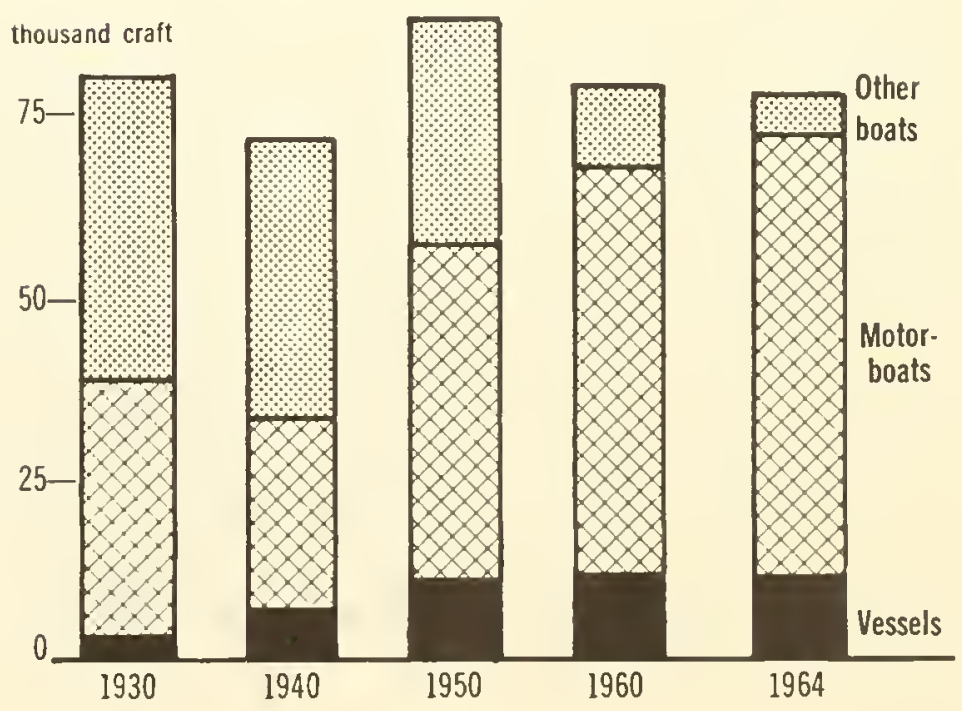


their vessel and gear will have a higher cost per ton of production than the new ressels and gear, and they will also require to change or go out of business. Theirs is a quite honest position having regard to their short-term interest. It is only disadvantageous when vicwed from the standpoint of the nation's interest in the use of the sea. This rigorous opposition is now still being expressed step by step in testimony respecting the applications for fishing vessel subsidies (Fishermen's News, Vol. 21, No. 5, March, 1965).

Protecting the numerous small inefficient fishermen in their ancient ways may appear to be sociologically gratifying and politically sound, but it is a poor way to run a fish business, and a poor way to run a society in these days of competition in all ficlds among nations in a troubled world. It is not the way we have done in agriculture. In that ficld the application of science and technology to the task of lowering the cost per ton of production has becn forced to the point that there never in history has been a society where so many have been fed through the labor of so few. Despite all the carping about agricultural policy, it has resulted in a magnificent food producing apparatus which is the solid heart of our economy, and which makes us strong among the nations.

This and other similar moves toward efficiency in other segments of the economy have not been uniformly blessed nor agreed to by the recipients of the programs. Pockets of poverty have been left behind as a result of this same resistance to change, or inequities resulting unnoticed from governmental actions taken, or simply the accidents of uneven growth and competition. It is the purpose of the War on Poverty, and the objective of the Great Society, to reduce these pockets of poverty one by one, to the end that we will all move forward tog ther as a prosperous pcople, thus making a strong and resolute nation.

The War on Poverty and the Great Society do not attempt to move by the general dole or the issue of bread to make the poor happy. These means have been tried in history and found wanting. The tactic now is to upgrade the poor sectors of the society by education so that maximum talents can be developed, to improve the infrastructure of equipment and apparatus so that the more effective training can be more efficicntly used, and to remove the economic and social shackles that have held thesc pockets in poverty-by carefully designed, cautiously implemented activities aimed at making each individual in the pocket more competent to contribute to the best of his native abilities to the welfare of himself and his family, and thus to the national whole.

In this process, the general conservative desire to remain as our fathers were, and not to change, requires to be mitigated in the national interest by some general improvement in the efficiency of the individual units of the society so that the whole society will remain strong and resilient. Automation brings these problems to industry; machinery and improved breeds of growing things have brought these problems to agriculture; and if our fisheries are to become competitive they must also yield to modern methodology, adopting all of the useful applications of science and technology that can be designed or discovered.
Only in this way can a progressive, moving society be created that can survive in this harsh and competitive world. If the individual will not more, then the society must move him, because it cannot afford to support too great a load of inefficiencr, and it must move in order to survive.

In the fisheries, the net effect of this fight against efficiency is implemented at the state level because it is at that level where our nation's fishcries are primarily regulated.

\section{State Fishery Research}

State legislatures, local authorities, local sportsmen's organizations and local industry people and associations tend to place their dependence upon the local state fisheries officials because they are part of the local community and have a close relationship to the local social conditions.

State fishery officials quite naturally depend primarily upon the scientific views of their own research laboratories. By and large, the state fisheries laboratories are not as effective as they might be from the standpoint of quality and quantity of top ocean scientists, floating equipment, laboratories, modern laboratory equipment and tools, and funds with which to conduct research. None will testify to this more rapidly than the directors of state fishery laboratories.

The reason for this is simple. The enthusiasm for ocean research which has grown over the past decade has passed over the state fisheries laboratories. The big new money has gone to the federal laboratories and to the academic institutions, which were badly in need of this shot in the arm.

The results, however, are that the new ships, the new laboratories, the glamorous ocean research projects, and the exciting scientific progress is at the federal laboratories and the academic institutions. Quite naturally, the bright young men go where the opportunities are most interesting. This is beginning to pay off in terms of general knowledge of the ocean and its resources and, as Dr. Schaefer will tell us this afternoon, we seem to be just on the threshold of whole new adventures in the use of ocean resources, if we are able to develop the competence to grasp the opportunities our own research is opening for everyone.

But the state apparatus has been left in the lurch by the passing times and it is at this level that the problems occur which generate the institutional barriers noted above, which prevent us in so many cases from using the research results to the nation's benefit.

To use California examples again, competent research has fully developed the knowledge that off southern California there is a largely unused resource of anchory that could stand an annual cropping of at least a half million tons with no strain. The information has come largely from federal and academic research; but the laws and regulations governing the use of the resource were generated on the state level. These anchovy still go unused because of these laws and regulations. The small boat fishery of southern California continues to go downhill. The fishermen see little reason why they should support research if they cannot use the benefits from it.

The same research has established the presence of about 3 
million tons of hake at least seasonally off southern California. They are not used by anybody. They can be caught, practically, only by midwater trawl. A fishing vessel, under antique California law, cannot have a traw aboard south of the Santa Barbara-Ventura county border.

I would not contend that a million dollars invested in state fishery laboratories would, at the present stage of history, yicld as much new knowledge and understanding of the ocean and its resources as if it were invested in research at federal laboratories and academic institutions. What I do say is that there is not much use in having new knowledge and understanding if you can't use them. We will only begin to free up our use of the ocean when the knowledge and understanding required for that freeing up is acquired and applied at the state level.

A start was made in this direction this ycar under Public Law 88-309 adopted by the last Congress, thanks again to the initiative of Senator Magnuson. Under its provisions, sums are to be made available to the states on a matching fund basis for these purposes up to a total of $\$ 5,000,000$ per year for a five year period. Naturally, and unfortunately for fishery development, the Bureau of the Budget subtracted the sums actually authorized for this purpose in the President's Budget for FY 1966 from the normal increases projected for the Bureau of Commercial Fisheries, so no net new money gain for ocean work was made, but that is about the best that could be expected from a land and space oriented Burcau of the Budget. The Housc Appropriations Committee in marking up the Interior Budget Bill in early April recognized the inequity of this conservatism to the national interest and appropriated twice the amount for these purposes that the Burcau of the Budget had allowed.

\section{Academic Fisheries Institutions}

Much has been made of the fact that the National Oceanographic Program Budget has risen from a level of about $\$ 24$ million in 1957 to $\$ 123$ million in 1964 , and (perhaps) $\$ 141$ million in 1966. No real complaint can be made by those interested in the budget of the Federal Bureau of Commercial Fisheries because it has participated in this general rise of money for ocean research. Furthermore, it has used the new money well.

The people who have been almost completely left out of this increase, oddly enough, are the academic fisheries institutions. The academic oceanography institutions have done very well. Funding is available for their work from the National Science Foundation, the Office of Naval Research, the National Institutes of Health, the Atomic Energy Commission, etc. But when a fishery scientist in a university makes a request for a research grant from one of these funding agencies, he is asked to take his business to the Bureau of Commercial Fisheries. For this reason there are not many fishery scientists in academic institutions in this country. The top young men go to the fields where money and exciting prospects are available. For these reasons the training of high quality fishery scientists languishes.
The Bureau of Commercial Fisheries budget, like that of most agencies of government, is established primarily for the support of in-house research and other activities. It fights for its budget increases in the Department of the Interior and in the Bureau of the Budget on that basis. It has the authority to make research grants to academic institutions and it does so on a small scale, but what money it uses for this purpose comes out of its regular appropriations for its own laboratories. It is naturally reluctant to favor academic fishery laboratories over its own, which are under steady pressure to get out more research results more quickly.

The result of all this is that academic fisheries research in the United States remains funded by state legislatures, a notably poor place from which to get ocean or other research funds. Accordingly, academic oceanographic institutions have grown like the green bay tree and academic fishery institutions have continued to starie. A natural result is that bright young men go where the money and excitement is, not to the dull, static, fishery fields.

All of this adds further to the difficulty noted above of having the fishery research done on the federal level and the fishery regulation done on the state level.

\section{The Organization of Ocean Research}

From what has been said above one might think that ocean research on the federal level and in the academic institutions has been thriving at a satisfactory rate. Nothing could be further from the case. While the National Oceanographic Program budget has been gradually working its way up from an annual level of $\$ 24$ million to $\$ 140$ million, the National Space Program budget has come from about zero to well over $\$ 5$ billion.

There is general support for the astronomical space budget and as a taxpayer I have no complaints of consequence about it either. The excitement and venturesomeness of learning about space is pay enough when one can afford it, and we all feel that we should at least keep up with the Russians even if we can't seem to pull very far ahead. Also our experience with basic research in this century indicates reasonable odds that all of this will pay off in the long run in some unexpected way. There is no question in anybody's mind that the impact of the space program on United States industry has not already been considerable.

But the industry associated with the ocean is also growing restless for support. The extent of this was indicated last year by an Ad Hoc Committee of the National Security Industry Association which considered and reported upon the National Ocean Program. It recommended the establishment of a $\mathrm{Na}-$ tional Ocean Science and Technology Agency quite frankly modeled on the Space Agency. It recommended budget lerels for it of $\$ 900$ million in 1965 rising to $\$ 3,100$ million in 1970 .

The Congress also grows increasingly restless. Senator Magnuson, for himself and nineteen other Senators, has reintroduced his bill to establish a National Oceanographic Council (S944). A number of identical bills have been filed in the House. Senator Bartlett, for himself and others, intro- 
duced S. 1091 to establish a Marine Exploration and Development Commission primarily aimed at developing the resources of the continental shelf. Congressman Ashley has introduced H.R. 6457 "to provide for a comprehensive, long-range, and coordinated National Program in Oceanography". Congressman Wilson has introduced H.R. 921 to establish a National Oceanographic Agency. Other bills have been introduced along similar lines in both Houses, and others are cxpected.

The genesis of all of this congressional activity has been that the national ocean activity is about as disorganized as it is possible for an important activity of the Government to be. Ocean research in the executive branch of the United States Government is spread among five Departments, three independent Agencies, and twenty-two operating Burcaus and Offices. Nobody concerned with this situation is happy about it except, perhaps, the Burcau of the Budget, which seems to like the policy of divide and rule.

Since 1959 there has been within the Federal Council for science and Technology an Interagency Committee on Oceanography. This excellent organization has striven mightly to bring some order to the National Oceanographic Program. As a matter of fact it created that entity in name, if not in full fact, from the bits and pieces of ocean research programs scattered around through the executive branch.

These men have done as well as they could under the conditions existing. They labor under major handicaps, among which are:

1) Each is responsible to a Department head and is not himself a policy-making official in his own Department.

2) Each has a full-time job to perform in his own Department and none can give much time, much less undivided attention, to a national ocean program.

3) As a group they can adopt a program and estimate the budget requirements for funding it. This they do. This has wo necessary relation to what budget emerges from the individual Departments to the Bureau of the Budget, or emerges in the President's Budget to the Congress, or from the Congress in the way of appropriations to the Executive for these purposes. There is no such thing as a national oceanographic budget, never has been, and if there were there would be no committce of Congress to which it could be submitted for authorization and no subcommittee of an Appropriations Committee to receive and act on it as one entity. While it is hardly believable, the national oceanographic program when it reaches the Congress is dealt with in bits and picces by thirty-two substantive and appropriations committees and subcommittees. It is an overstatement to say that there is little communication among these committees on ocean planning.

Accordingly, there is nothing that can reasonably really be called a National Ocean Program, or a Budget for such.

The striving of the numerous Senators and Congressmen who have introduced bills dealing with this subject in this and previous sessions is aimed at reducing this chaos to some sort of order. In this respect all of the bills mentioned above are steps in the right direction. I personally favor S. 944 of Senator Magnuson (and companion bills in the House) and S.
1091 of Senator Bartlett (and companion bills in the House). Both are very sound bills and would mark solid advances in the right direction. As a matter of fact, they have a good deal in common, although one is aimed primarily at the continental shelf and the other at the ocean. One would hope that they could be combined, retaining the best features of each, and the combined bill adopted by the Congress this session.

\section{A Suggestion}

I have no illusion, however, that the formation of a National Oceanographic Council, as envisioned by Senator Magnuson and his colleagues, would be a general panacea to secure an effective National Ocean Program. There would still be too many Departments and Agencies dabbling in ocean activities on too small a scale, and too many committees of Congress adding their comments.

I think that a necessary companion action is to group several of the major ocean-oriented operating offices and Bureaus together into a full-fledged Department of the Ocean, having the same status as the Department of the Interior, the Department of Commerce, etc., with a Secretary of Cabinet rank.

I suggest that this new Department of the Ocean should be composed of the following Agencies and Bureaus, amongst others:

U.S. Maritime Administration-U.S. Weather BureauBurcau of Commercial Fisheries--U.S. Coast GuardU.S. Coast and Geodetic Survey-National Oceanographic Data Center-Coastal Engineering Research Center-and the Sea-Air Interaction Laboratory.

The Maritime Commission is presently in the Department of Conmerce, which is concerned mainly with land-based industry problems. The Merchant Marine establishment should be with other major civilian ocean activities in the Department of the Ocean. The sense of this is recognized by the House of Representatives which has a Committee on Merchant Marine and Fisheries. Both activities also come within the purview of the Senate Committee on Commerce.

The U.S. Weather Bureau also is presently in the Department of Commerce for no better reason than that there was no other place into which it fitted better. The growing understanding of the controlling part the ocean plays in climate control makes a move of this Bureau to the Department of the Ocean logical.

The Bureau of Commercial Fisheries started out in the Smithsonian Institution, then went to the Department of Commerce, and lastly was grabbed by Harold Ickes into the Department of the Interior, of all places. An ever-increasing part of its activities has been concerned with the international high seas, relations with foreign governments and their fishermen, participation in international ocean science programs, participation in the activities of international conservation agencies covering the high seas, and work with the specialized agencies of the United Nations. Its field of work is in the exterior, not the interior. This will continue to be the case increasingly as the xcean fisheries of the world continue their rapid growth, whether we participate in that growth or not. 


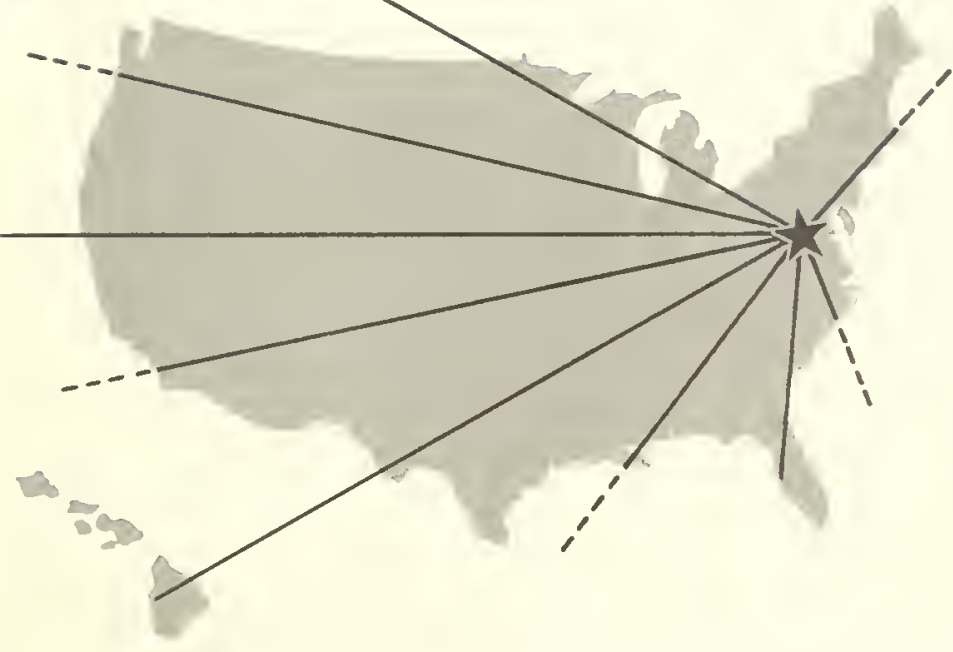

The U.S. Coast Guard is in the Department of the Treasury in peace time and in the Department of the Navy when the country is at war. It has finally been authorized by the Congress to engage in ocean research other than chasing icebergs and fur seals. Its ancient reason for being in the Department of the Treasury was to protect the revenues derived from customs. In these days of diminishing tariffs and the free use of alcoholic beverages there seems to be no real reason for it being an orphan in that Department, which has no other substantial ocean interest.

The U.S. Coast and Geodetic Survey is in the Department of Commerce for about the same reason that the Maritime Administration is. There was no other better place to put it. Its work is almost exclusively concerned with the ocean. It, with the Bureau of Commercial Fisheries, are the two key civilian ocean research Bureaus of the Federal Government.

The National Oceanographic Data Center is a recent confection whose organization in some ways typifies the organizational disarray of ocean matters in the United States Government. It is in the Office of the U.S. Navy Oceanographer for housekeeping purposes with the clear understanding that he is to have no unique policy control over its operations. It is funded by contributions of the several executive agencies that use its services. It has no regular appropriation of its own, although its data are the key element in the entire National Ocean Program. Its operations are pretty well ordered by an Advisory Board composed of distinguished scientists, some in the government and some not. Obviously this is the data heart of the Department of the Ocean.

The Coastal Engineering Research Center is a new name for the old Beach Erosion Board and is in the U.S. Army Engineers Corps. The justification for it being in the Department of the Ocean appears plain, as there would not be much beach erosion without ocean action. The relation of this work to that of the Department of the Army is a little obscure and its scientists are, of course, civilian.
The Sea-Air Interaction Laboratory is a new creation put in the Department of Commerce last year for lack of a better place. Since $71 \%$ of the earth's atmosphere overlies the ocean, and the occan is a prime source of the energy driving the winds, the reasons for it being included in the Department of the Ocean are reasonably obvious.

If all of these Agencies and Bureaus were placed into a Department of the Ocean, ocean affairs of the United States Government would be consolidated into three large, wellbalanced units, and a number of splinters in the Bureaus and Agencies whose major activities are land oriented.

The three major ocean outfits would be:

1) The Department of the Navy-Military

2) The Department of the Ocean-Civilian Industry, and

3) The National Science Foundation-Academic

There would still be a number of Agencies and Bureaus which had activities in respect of the ocean which are necessary for them to continue but minor in scope relative to their total activities. These include the Atomic Energy Commission-The Bureau of Mines--The Geologic Survey-The Bureau of Sport Fisheries and Wildlife-Public Health ServiceOffice of Education-and-Smithsonian Institution.

There would still be scope for an Interagency Committee on Oceanography for correlating the work of these entities in the ocean with the three major Departments noted above.

\section{Conclusions}

We have been talking about the future of North American fisheries and all of what I have said above is intended to bear upon the questions Dr. Kask has raised as to why these fisheries do not flourish as do those of some other countries in Asia and Europe. Several people in the fishing industry and some in the Congress have expressed the view that we should extend our jurisdiction far out to sea and protect our coastal resources from the fishermen of Asia and Europe. What they mean is that we should try to obtain exclusive rights to these resources because our foreign competitors are out-competing us off our own beaches.

There is something ludicrous in the United States even considering such a departure in policy, much less talking about it in public. In this country we boast of the power of our competitive economy, our managerial and governing skills, our scientific and technological contribution to human progress, our elevated standard of living, the high level of education and training of our common people which gives us industrial strength and good government, our ability to automate everything and run it by computers, and above all our ability to rule the waves every bit as good as old Brittania ever did.

But some, nevertheless, seek to raise imaginary lines in the ocean contrary to international law, the nation's interest, and the policy that has served us well since Thomas Jefferson enunciated it. Across this line other fishermen should not come one way, nor fish go the other. These are our fisl with American flags on them and they should know enough to stay home. Other fishermen should not catch these fish which wear American flags. 
The whole thing is so ridiculous as to be embarrassing to speak about. How the rest of you many stand, you can say. But for me, the course is clear. The thing to do is use some initiative, cnergy, and common sense and get out on the high seas with the rest and compete.

One of the more amusing aspects of this is that if we attempt to move our fishery control boundarics out to sea, and are successful, without modernizing our state laws regulating our fisheries, we will only drag our self-imposed handicaps further out to sea with us and be no better off in the cnd.

\section{Summary}

In closing, these remarks may be summed up as follows:

1) In order to successfully compete in the American good market, fishery products must be made more desirable, nust be more quickly adapted to changing eating customs, and be made cheaper in cost.

2) To do this the cost per ton of producing the raw material must be reduced by the application of science and technology to the fishing process (see Schaefer: Oceanograply and the Marine Fisheries).

3) To do this, the archaic systems of statc law regulating the fisheries require to be examined state by state and overhauled so as to permit the rational and efficient harvesting of ocean resources. The adoption of S.J. Res. 29 (Magnuson and others) by this Congress would begin this process.

4) To do this, accommodations must be made at the state level betwcen the recreation industry and the food industry over the use of the various resources.

5) This can scarcely be done until a decision is made at state level to favor efficient fishermen over inefficient fishermen, or at least to give them an even break legislatively.

6) None of these thing; secm likely to occur until state fishery laboratories are put on such a footing that they can provide competent scientific advice at the state level for the use of state fishery officials, legislators, sportsmen's and commercial fishermen's representatives, and the general public. While this requires many things, money is the one thing that it must have and Public Law 88-309 of the last Congress is a proper vehicle for providing it.

7) This process would be much enhanced if academic fisheries institutions in the state universities had access to funding from the National Ocean Program budget on the same scale as do the academic oceanography institutions. Moves by Senators to put money in the FY 1966 budget to start this process should be applauded and urged.

8) The organization of ocean research in the Federal Govemment is in disarray and for that reason ocean-oriented activity by government and industry languishes. Several bills presently before the Congress are aimed at improving this situation and among the most practical of them are S. 944 ( $\mathrm{Nag-}$ nuson and others) and S. 1091 (Bartlett and others). It is to be hoped that they will be combined and adopted by this Congress.

9) There really is no National Ocean Program or Budget. Ocean activities are conducted by 5 Departments, 3 Independ- ent Agencies, and 22 operating Bureaus and Offices in the Executive Branch of the Federal government. They report to 32 substantive and appropriation committees and subcommittees of the Congress. The Interagency Committee on Oceanography is not statutorily authorized to deal effectively with this mess, and the Congress is not organized effectively to receive its product if it were.

10) Aside from the rcorganization of ocean affairs in the Federal Government as envisioned by Senator Magnuson, Bartlett, and others, there requires to be created in the exccutive a civilian Department of the Ocean with a Secretary having Cabinet rank. To this, as a minimum, should be transfcrred:

U.S. Maritime Administration, U.S. Weather Burcau, Bureau of Commercial Fisheries, U.S. Coast Guard, U.S. Coast and Geodetic Survey, National Oceanographic Data Center, Coastal Engineering Research Center, and the Sea-Air Interaction Laboratory.

11) Segments of the United States fishing industry and their representatives should quit bellyaching about needing protection from foreign fishermen, pull up their socks, wipe their noses, and get out on the high seas and compete with all hands in the rational use of the occan's bounty under the terms of the 1958 Convention on Fishing and the Conservation of the Living Resources of the Sea. They will be helped in doing this if some of the other suggestions made above are followed.

The Committee on Oceanography of the National Academy of Sciences-National Research Council in a recent publication on "Economic Bencfits from Oceanographic Research" has estimated that rational development of the U.S. domestic fisheries could result in doubling production in the next 10 to 15 years, and that the continuing accelerated growth of our distant water and overseas fisheries could increase their production fourfold within the next decade. Oceanographic research is one of the essential elements in realizing these potential developments. My purpose here is to discuss some of the ways in which oceanography is useful in increasing the harvest of the living resources of the sea.

By "oceanography," I mean the study and understanding of the ocean, its contents, and its boundaries, including the effects of atmospheric processes exerted on the ocean at the air-sea boundary. Fisheries oceanography is concerned with all the aspects of the ocean, its boundaries and its contents which affect the abundance, location, and behavior of the harvestable living resources. It thus comprehends not only the topography of the ocean basins; the currents, upwellings, and other motions of the ocean; the distribution of temperature, salinity and other physical and chemical properties; but also the abundance, rates of production, behavior, and interrelationships of the populations of the living elements. It includes much of what is often called fishery biology, fishing ecology, and fishing exploration. The fishery oceanographer is particularly concerned with the ocean conditions that bring about economically catchable fish concentrations; how the locations and sizes of fish populations vary with changing conditions in the sea; and those aspects of fish behavior that can be exploited to reduce the costs of catching the fish. 


\title{
Oceanography and the Marine Fisheries
}

\author{
by Milner B. Schaefer \\ Director, Institute of Marine Resources \\ University of Califormia \\ La Folla, California
}

Oceanography, for fisheries or any other purposes, is concerned with describing the distribution of physical, chemical and biological properties and their changes in space and time, and with understanding the forces and processes that bring these things about, and the interrelationships among all of the different factors. The descriptive phase, that is determining what happens when and where, is of considerable use to the development of the commercial fisheries. However, understanding why brings the application of the observations to much firmer ground, especially when it comes to reliably forecasting future events.

At the present stage, the descriptive aspects of occanography are rather better advanced than the analytical aspects, but large and rapid advances have been made in both since the end of the last grcat war, and particularly during the past decade. During this period we have obtained a vastly increased store of observational data, and there have been large increases in our understanding of the basic physics, chenistry, and biology of the oceans, and of the ecology and behaviour of populations of harvestable living organisms. The oceanographers' increasing capabilitics to provide the information and understanding on which to base fisheries development is due in no small part to new developments in precise, rapid and sophisticated instrumentation and methods of observation. Observational coverage of the ocean has become more extensive and more intensive, both by the employment of many more research vessels, and by development of improved systems of data acquisition from the fishing fleets, merchant fleets, weather satellites, and so forth. Finally, we are enabled quickly to digest vast quantities of ncw information bccause of the development of rapid data processing systems, using high speed computers.

Oceanographic knowlcdge assists in increasing the harrest of the sea in five ways: (1) Location of new highly productive fishing areas. (2) Identification and location of promising unutilized fishery resources. (3) Providing the fisherman information which he can use to improve his tactical scouting and catching opcrations. (4) Forecasting space and time variations in the abundance and catchability of fish populations. (5) Providing the scientific basis of rational management of the heavily exploited fisheries. I will deal here with the first four of these topics, passing over the fifth, despite its very great importance, because of the limited time allotted for this presentation, and becausc it is a subject with which I am sure you arc already very familiar.

\section{Location of new productive fishing areas}

Until 10 or 15 years ago, new fishing grounds wcre, with few exceptions, discovered by venturesome fishermen, and occasionally by governmental fishery explorations, trying out new areas, with little or no help from physical or biological oceanography. Following the discovery of new fishing areas by such exploratory fishing, the oceanographers came along and found out why these areas were highly productive. In each case, they found that the rich fisheries occur at or near those locations where large quantities of organic matter are produccd by the phytoplankton, due to fertilization of the sunlit upper layer of the sea by upwelling, mixing along current boundaries, winter overturn, stirring of nutrients up from shallow bottoms, or other physical processes. With increased capabilities for studying the ocean circulation, for directly measuring phytoplankton productivity, for assessing abundance of larger organisms using underwater sound and other techniques, and with increased understanding of why the fertile ocean areas are fertile and the desert areas are desert, the occanographers have become of more use in pioneering in the location of promising new fishing areas.

For example, the northwest coast of Africa has long been known to be a region of strong coastal upwelling, and measurements of basic productivity and standing crops of phytoplankton indicated that there should be abundant populations of organisns which might be haricstable by the commercial fisheries. This led to cxploratory cxpeditions by the Russians, and more recently by others, including some from the United Statcs, to cxamine into the fishery potential of this area in relation to oceanographic factors. In consequence, there have becn discovered sizeable populations of tunas, of Sardinella, and of various demersal specics as well.

Investigations of the physical and biological oceanography of the equatorial Pacific, in adrance of and along with exploratory fishing operations, have greatly accelerated the devel- 
opment of the pelagic fisheries for tunas and spearfishes, conducted mostly by Japanese fishermen.

The most recent cxample is the incipient development of a large new fishery on the western side of the Indian Occan which, I am sure, will be of major importance. Studies of this area carricd out cooperatively during the Indian Ocean Expedition by occanographers of the United States, England. Russia, and other countries demonstrate that this is a region of high basic productivity, associated with vertical circulation related to the monsoon winds, and there have been observed sizeable populations of sardines, mackcrels, tunas, and other fishes.

Other examples of the utility of oceanography in the location and development of rich new fishing arcas are the fisheries developments which are just commencing off the coasts of Chile and Argentina.

\section{Identification and location of unused resources}

Even in those areas of the sea which have been long exploited by the commercial fisheries, systematic scientific observations may lcad to the identification of important latent resources. For cxample, the systematic studies of the Califormia Current, which have been going on for a number of years, and which had as their initial motivations the investigation of the ecology and fishery dynamics of the California sardine, have led to important discoveries of unused resources. Onc of the techniques of these investigations is systematic surveys of the occurrence of sardine larvae and other fish larvae. One dominant element in the catches of fish larvac is the Pacific hake, from which it was inferred that there is a large latent resource of this species which might prove to be commercially exploitable. Following this lcad, systematic explorations by echo sounding and by experimental trawling, have revealed large commercially exploitable concentrations along the coast of Washington, Oregon and northern California. It appears that this species moves south and somewhat offshore to spawn, and moves north on a fecding migration, although many of the details remain to be worked out. Whether the stocks are commercially exploitable, not only off Washington and Oregon, but also to the south in the vicinity of the spawning grounds remains to be investigated. These systematic surveys of fish lavac have also revealed that, with the decline of the sardine population, ite close competitor, the anchory, has increased very greatly in abundance. Scientists of the California Cooperative Fishery Investigations estimate that there is off California and Baja California a standing stock of some two to four million tons of anchovies, that could sustain a harvest of perhaps half a million tons per year, or more, and they believe that the reduction of the anchovy population might, at the same time, accelerate the recovery of the sardine population. These investigations have also indicated that the stock of jack mackerel, of which only some 40 to 50 thousand tons per year are currently harvested, extends westward over a vast region of the Pacific and could support a much larger fishery.
Another example of systematic observations revealing an unrealized resource is the recent development of the expanded fishery for swordfish in the northwest Atlantic, employing floating long-lines at night. This was discovered, almost accidentally, by our colleagues at Woods Hole Oceanographic Institution in the course of their studies related to the bluefin and ycllowfin tuna.

\section{Fish behaviour in relation to catching operations}

The forcgoing kinds of information are helpful to the fishing industry in indicating those sea areas, and often also the particular seasons, where abundant exploitable populations occur. The fisherman has, however, additional problems of locating fish shoals within a general area and then of catching them rapidly and efficiently. Knowledge of the local distribution of the fish in relation to the properties of their environment, and knowledge of their behaviour, especially as it may vary in relation to measurable properties of the environment, can be useful to the fisherman in his tactical operations. If the oceanographer can indicate to the fisherman what measurements he himself can take at sea in order to guide his scouting and catching opcrations, this can increase his efficiency and cut down his cost of production. Some success has been achieved in these matters, but I an sure that we can do a good deal better as we learn more.

One of the things that both scientists and fishermen have known how casily to measure for a great many ycars is water tempcrature, both surface and subsurface. Also, the surface tempcrature of the ocean is the one physical measurement that is, and has been for many years, routinely observed as part of the merchant ship weather reporting system. Consequently, we have been able to learn a good deal about the local distributions of some kinds of fish in relation to temperature, and this knowledge can be of some tactical advantage to the fishermen. A few examples:

The North Pacific albacore, which are summer visitors to waters off the west coast of the L'nited States, prefer water of temperature 60 to $66^{\circ} \mathrm{F}$, about two-thirds of the total catch being madc in waters of these temperatures. In directing their scouting operations, therefore, it is useful to the fishermen to consult the sea-surface temperature charts which are published by the Bureau of Commercial Fisheries at two-week intervals during the summer, and to take their own temperature measurements while searching for the albacore schools.

It the northern and southern extremes of their ranges, the distributions of the tropical tunas, yellowfin and skipjack, vary in relation to the water temperature, being limited by the lowest temperatures in which these species occur in commercial concentrations. Within the range of tolerable temperatures, however, the location of fish concentrations appears to be related to the food supply. All along Baja California there are large crops of forage organisms at all times of the year, yet the yellowfin tuna are found in there in commercial quantities only in waters of about $19^{\circ} \mathrm{C}$ and warmer, while skipjack occur in somewhat cooler water, down to about $17^{\circ} \mathrm{C}$. These temperatures also limit the distributions of these species at the southern 
end of the range, off Peru and Chile. This knowledge of relationship between water temperature and occurrence of commercial concentrations of tropical tunas is not of great utility to California tuna fishermen at the northern end of the range, since the vessels must traverse these waters in any event to get to the fishing areas to the south. However, off Peru and Chile. the fishermen can benefit both from consulting the temperature charts which are issued at monthly intervals, and also by using their own thermometers as an aid in their scouting operations.

Investigations of the distributions of cod in relation to temperature in the vicinity of Bear Island, between Norway and Spitzbergen, by English scientists, have revealed useful relationships between the bottom temperatures and the location of paying concentrations of cod. It has been shown that paying quantities are rarely caught in water colder than $1.75^{\circ} \mathrm{C}$, except in summer when the fish are feeding heavily to the east of Bear Island and may be found down to $-0.5^{\circ} \mathrm{C}$. In early summer and autumn, on grounds west of Bear Island, Atlantic water touching the Bear Island banks can give good cod catches with bottom temperature between $3^{\circ}$ and $5^{\circ} \mathrm{C}$. Thus, measurements of bottom water temperature can be useful to the trawlers in searching for concentrations of cod in this area.

Another relationship of tuna to their environment which appears to be of tactical value to tuna fishermen is the distribution and behaviour of the tropical tuna (in the eastern Pacific at least) in relation to the depth of the mixed layer and the structure of the underlying thermoeline. The schools of tropical tuna occur in the upper mixed layer of warmer, low density water, which may vary from 10 to 80 meters deep, and which is underlain by colder water, the sharpness of transition (from the upper mixed layer to the underlying water), called the thermocline, being variable. Data respecting the percentage of successful purse-seine sets on tuna schools in relation to these factors indicate that the schools escape through the bottom of the net less frequently when the mixed layer is shallow, especially when it is shallower than the depth to which the net fishes, and when the gradient of temperature in the thermocline is very sharp. By measuring the vertical distribution of temperature, by bathythermographs or other means, the fishermen may, therefore, assist themselves in selecting situations where the escape rate is minimized.

A local phenomenon which often corresponds to fish concentrations is the occurrence of fronts, which are boundaries between water masses. Along such boundaries, which can often be located by sharp temperature transitions, differences in water color, and occurrence of floating debris, the associated vertical circulation often concentrates the plankton organism, which in turn leads to concentration of forage fishes and of the predatory fishes which prey upon them. Japanese long-line fishermen, for example, find that laying their gear along and across such fronts, which the Japanese call "siome", improves their fishing success. Similarly, the near-surface schools of pelagic fishes are frequently found more abundant near these features.

It is also well known that tunas, as well as some other marine fish species, tend to be more concentrated in the vicinity of sea- mounts, which the fishermen refer to as "banks". The discovery of new seamounts, both by the fishermen and by our submarine geologists have, therefore, led to the discovery of increasing numbers of good fishing spots. Bottom topography charts, together with echo sounders, thus can be used by the fishermen to good advantage.

The relationships of the harvestable fish to aggregations of their food organisms is also a potentially useful tool which fishermen may sometimes use to improve their own fishing operations, although this is not as yet very well developed. For example, the relationship between herring and the copepod Calanus on which it feeds is sufficiently close to assist the fishermen in locating herring by their own plankton collections in at least some situations in the North Sea and in the Barents Sea. Such simple instruments as the Hardy plankton indicator have been developed for the use of the fishermen in these situations.

\section{Forecasting space and time variations}

What both fishermen and fish processors would most like to have from oceanographers are reliable future forecasts of fishing locations and expected catches of particular kinds of fish.

To make such forecasts for any kind of fish, we need to have useful estimates of the magnitude of the exploitable fish populations, understanding of the distribution and behaviour of the fish in relation to measurable properties of the ocean (such as temperature, salinity, depth of mixed layer, strength of currents and upwelling), and means of predicting the space and time changes in the oceanic properties and processes. Considerable progress has been made on all of these, and in some instances useful forecasts a few to several weeks hence are possible. But we have yet a long way to go.

Through the compilation and analysis of statistics on catch and effort, and age composition of catches, supplemented in some instances by estimates of abundance of young fish prior to their entry into the stock of commercial sizes, methods have been developed for forecasting the magnitude of fish populations which will be available to the fishery. Well known examples are the New England haddock, Bristol Bay red salmon, sockeye and pink salmon of the Frazer River, yellowfin tuna of the Eastern Pacific, California sardines and anchovies.

As already noted, we have also some useful, but primitive, understanding of the relationships of some kinds of fish to environmental factors, usually temperature. One example not yet mentioned is the skipjack population of the Central Pacific near the Hawaiian Islands, a large component of which inhabits the waters of the California Current Extension, identifrable by temperature and salinity. As these waters shift northerly through the vicinity of Hawaii each summer, the "season" skipjack appear, their availability varying with the time and extent of the shift in the boundary between the California Current Extension and the water mass to the north. Another well known, large scale phenomenon is the "EI Niño" off northern South America, which, at irregular intervals, averaging about seven years, brings abnormally warm surface waters to the coast of Peru, resulting in great shifts in the populations of 
anchories, bonito, tuna, etc, and catastrophic effects on the guano birds.

Forecasting of ocean conditions, and hence of effects on the fisheries, is presently" mostly what might be called "pattern and persistence" forecasting, supplemented to a limited extent by knowledge of the dynamic processes of the atmosphere and the sea. This is rather similar to much local weather forecasting, and is not very satisfactory. We rely on the facts that changes in the upper layer of the ocean, which are fundamentally due to the wind-driven circulation and the water and heat exchanges betwcen sea and atmosphere, tend to occur in repetitive pattern, and that anomalies tend to persist for some wecks. The ocean is considerably more sluggish in its changes than is the atmosphere; it has been said that a week in the occan is comparable to a day in the atmosphere.

This type of forecasting has enabled oceanographers to make useful predictions in the early spring of the success of the skipjack fishery near Hawaii during the summer. Similarly, from temperature and salinity distributions and trends off the United States west coast, forecasts are made each year of the expected catch of the alloacore and bluefin tuna, and of the most probable areas of good albacore fishing. From the trends of temperature, which affect growth of kelp, it is possible to make some very general estimates of the expccted kclp harvest along southern California. Upwelling in the Gulf of Panama, which influences the abundance of pink shrimp in shallower waters during the winter months, can be forecast somewhat better than chance. The continuing monitoring of the Peru Current by the Instituto del Mar der Pcru has enabled short-term forecasting of success of anchovy fishing there.

We are, I believe, on the threshold of being able to do much better, through monitoring of atmospheric circulation and heat exchange between sea and atmospherc. As I have noted above, these are the principal driving forces on the upper layers of the sea, and the dynamic relationships between them and the occan circulation are becoming increasingly better understood. It should soon be possible, given an adequate network of stations for observations of the atmosphere over the sea and of the upper laver of the ocean, by automatic unmanned stations (meteorological and oceanographic buoys) both to kecp track of what the ocean is doing, in real time, and to forecast changes which will affect the fisheries.

To enablc a really large advance in oceanographic forecasting, the olservational net must be sufficient to describe the entire physical system, consisting of the atmosphere and the upper mixed layer of the sea for the whole globe, or at least a hemisphere. The cost of such a data acquisition system, and associated processing by computers, will be large, much larger than can be supported for fisheries alone. Fortunately, the same kind of ocean forecasting that is needed by the fisheries interests is also needed for other purposes, such as weather forecasting, ship routing, and several aspects of military ocean operations. We may hope to have such a system of data acquisition, and processing in real time, which is now within our technical capability, in operation within the coming decade. 


\section{Relentless Study of the Sea and Its Riches}

Today, two of every three people in the world suffer from diseases brought on by protein deficiency. If the resources of the sea were harrested to a greater extent and distributed more widely, they could alleviate this problem.

In the years ahead, a crowded, hungry work may be forced to depend heavily on these resources.

Oceanography can locate the riches of the sea-and benefit the hungry millions and improve the economy of many nations.

In 1957, the United States spent less than \$35 million annually to study the oceans. In 1965 , the figure is nearly $\$ 200$ million; the Departurent of the Interior's share is $\$ 20$ million, nearly all of it assigned to the Bureau of Commercial Fisheries (BCF).

While BCF's oceanographic research tries to solve immediate problems of the fishing industry, its goals are primarily long range. $\mathrm{BCF}$ scientists seek to understand the interrelationships between major aquatic resources and their environment in the Pacific, Gulf of Mexico, and in the Atlantic. They gather infornation needed to properly conserve, manage, and utilize these resources. They look for new fisheries and work to cxtend existing fisheries.

The scientists search for an understanding of the natural phenomena in oceans, coastal waters, and estuaries that affect fishing success and influence the distribution and abundance of fish and shellfish.

To make greater headway in solving these problems, BCF nust satisfy certain major needs. It must:

- Assist in compiling an inventory of the world's fishery resources: the number, distribution, rate of turnover-and prepare atlases showing distribution and seasonal variations.

- Carry out longer time series of observations in order to refine predictions and determine causes of fluctuation. Prediction of coming events is one of industry's biggest needs.

- Gather essential information for management on size, homogeneity, variations of stock, rates of recruitment and growth, natural and fislning mortality, population dymamics.

- Assist in collecting accurate and worldwide data on catch and effort expended.

-Gain better understanding of fish physiology and behavior, genetics, predation, diseases, and taxonomy.

- Study new fishing methods, to include such possibilities as electrical fishing, giant midwater trawls, and remotely controlled fishing submarines.

-Devise new methods of sampling the biota, try new ways of studying behavior and ccology of organisms, and develop new scientific instruments and fishing gear.

The photographs on the following pages illustrate the relentless study of the sea and its riches.

Tuna seen from observation chamber of research vessel.

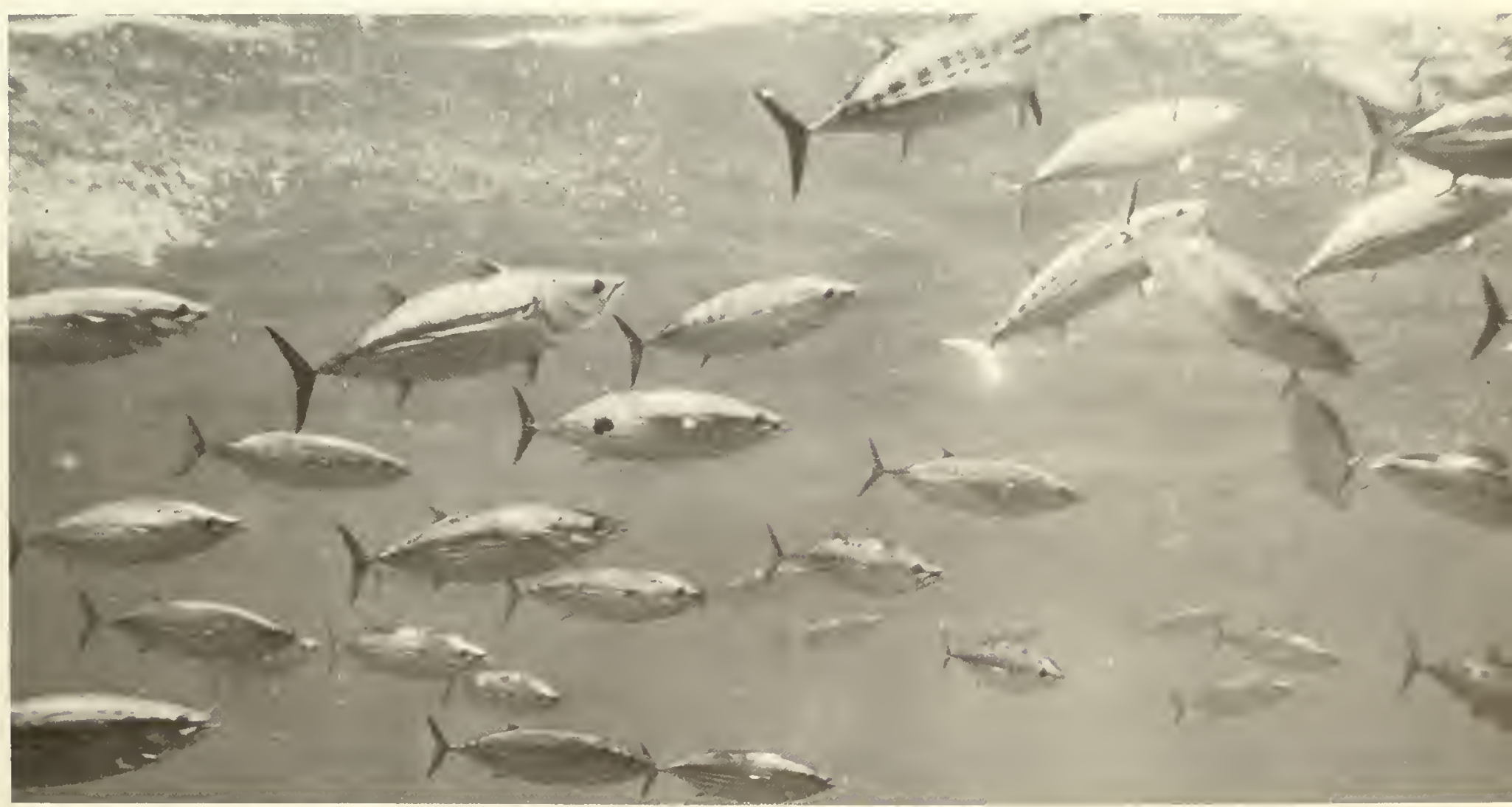




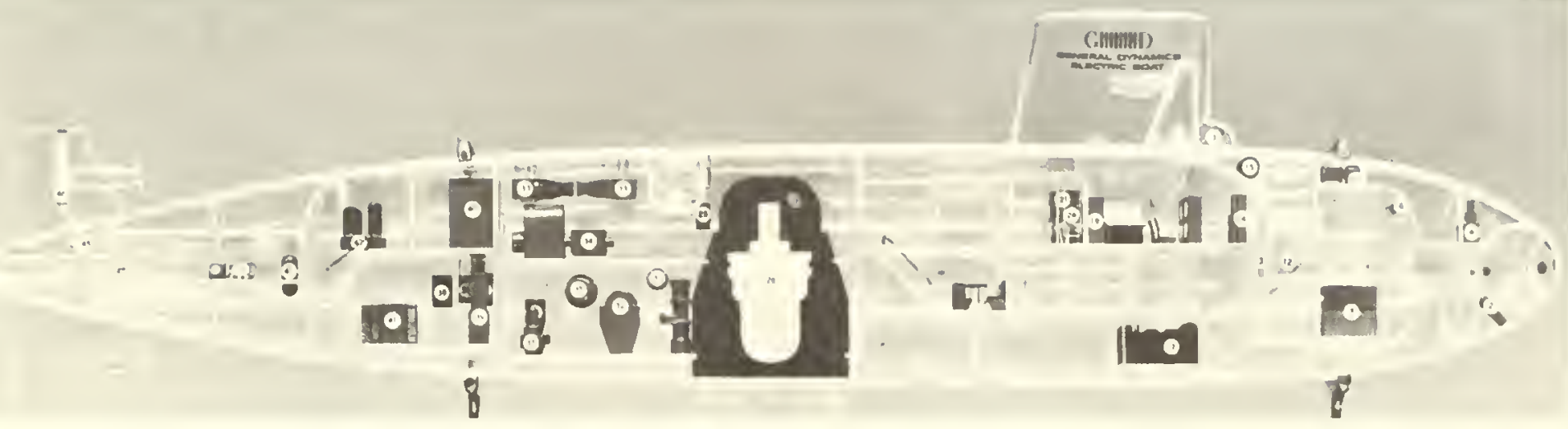

Model of 163-foot fishery research submarine under study by BCF. Powered by nuclear reactor, sub would reach 10 knots at surface, 20 knots submerged, have depth capability of 1,000 feet, and carry crew of 24 plus 7 scientists.

Aluninaut, world's first aluminum submarine, was built for oceanographic projects. The 51-foot, 81-ton sub, owned by Reynolds, was launched in 1964. It has average speed of 2.5 knots and, in 1965, set depth record of 6,250 feet in trial dive in Bahamas. It carries crew of 3 and

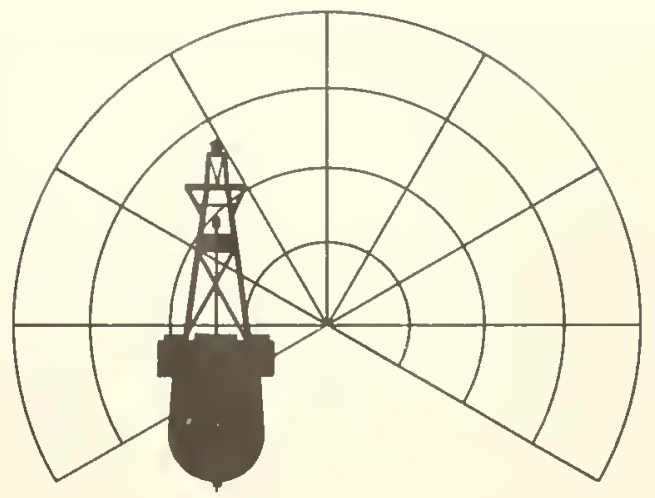
$6,000-$ pound scientific payload.

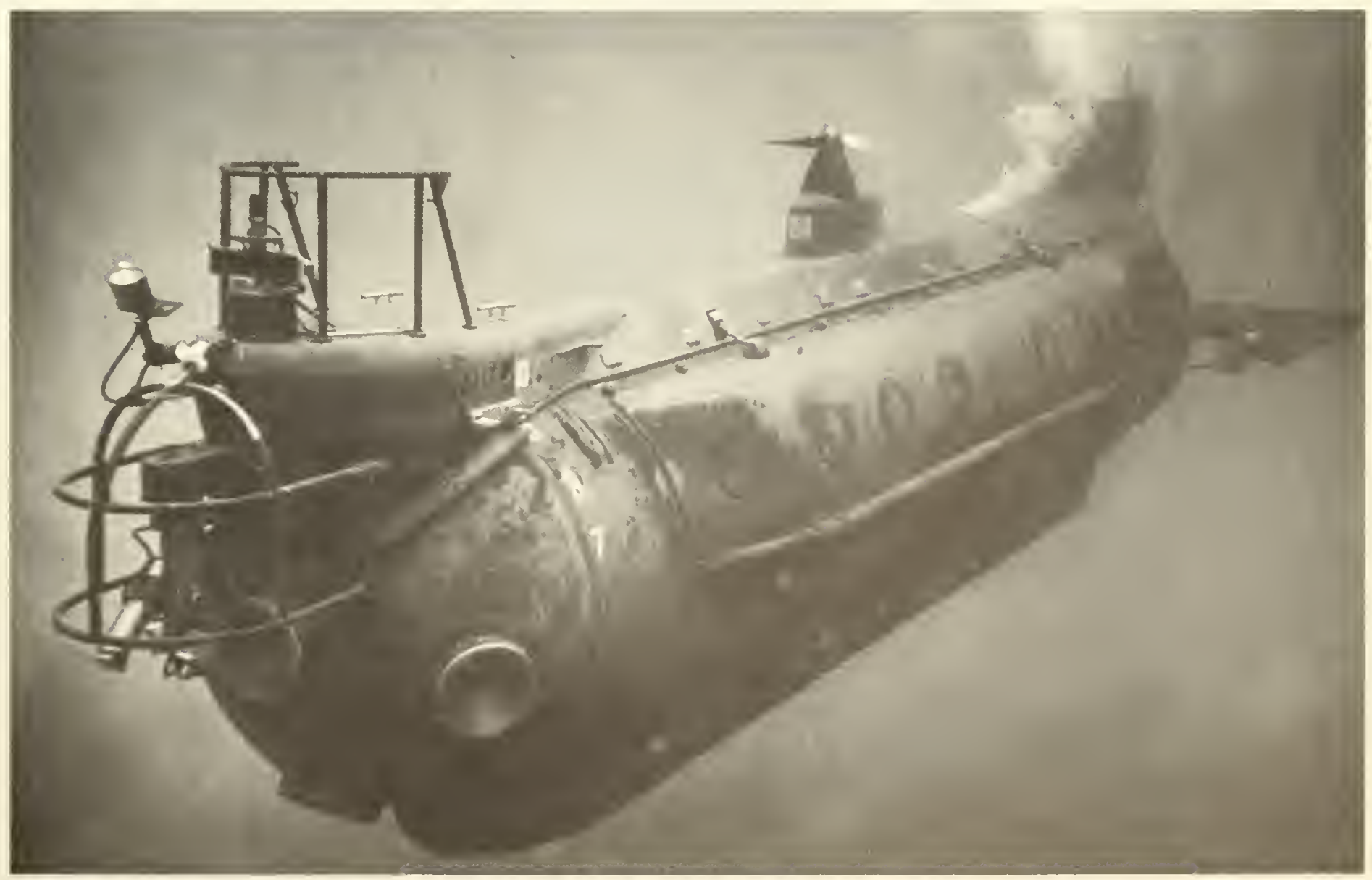




\section{ABOVE ...}

At 500 feet, the horizon is nearly 30 miles away from observers in gondola.
Dacron balloon, 52 feet in diameter and attached to vessel by cable, lifts observers to spor fish.
200 miles south of Tokyo, a new island group pushes its way up from sea floor. Navy photographers noted green muddy discoloration of the sea. New reef may result in new fishing bank. 


\section{and from the SURFACE}

Nansen bottle is attached to wire to obtain temperature, pressure, and water sample at predetermined depth.
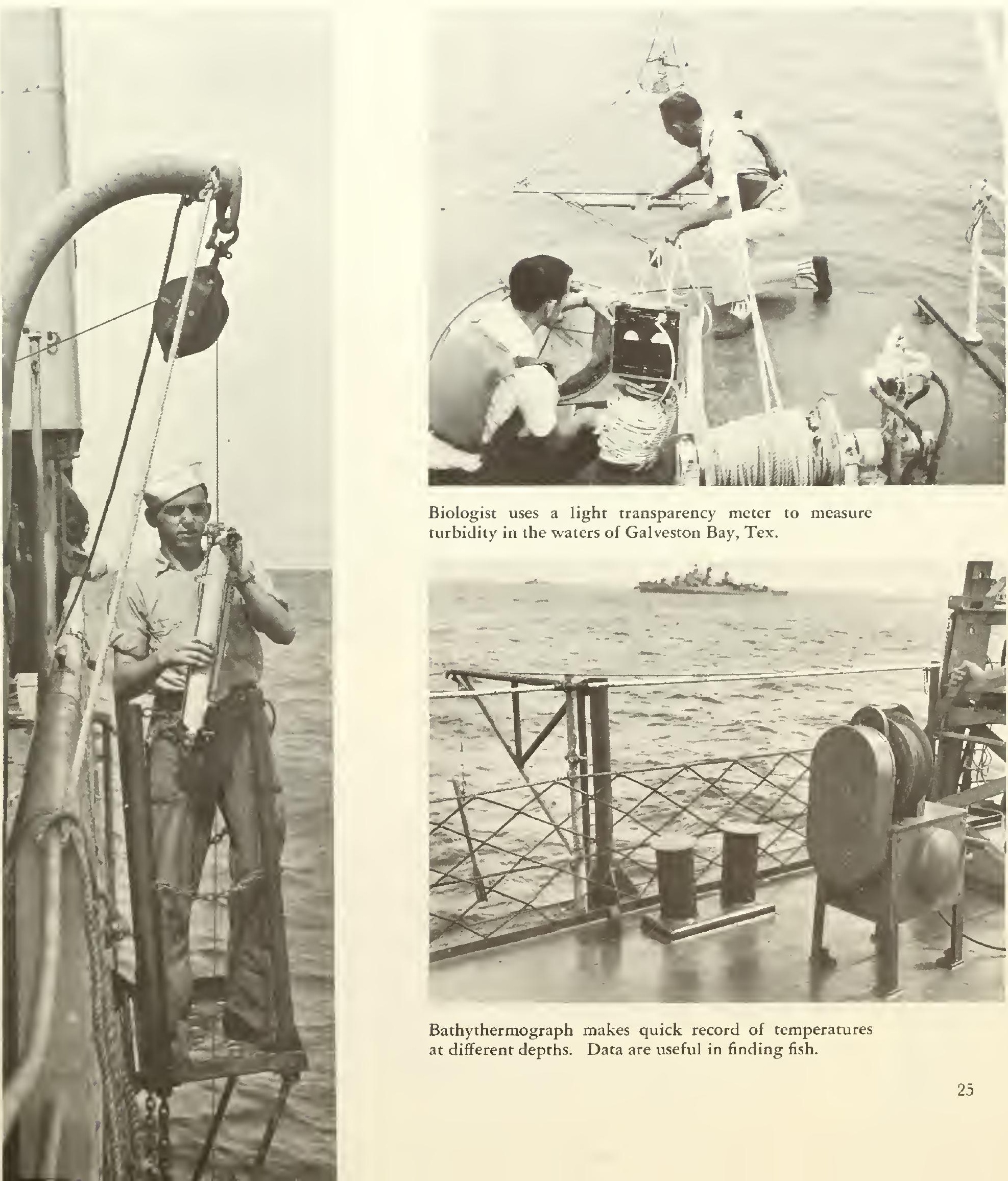

Biologist uses a light transparency meter to measure turbidity in the waters of Galveston Bay, Tex.

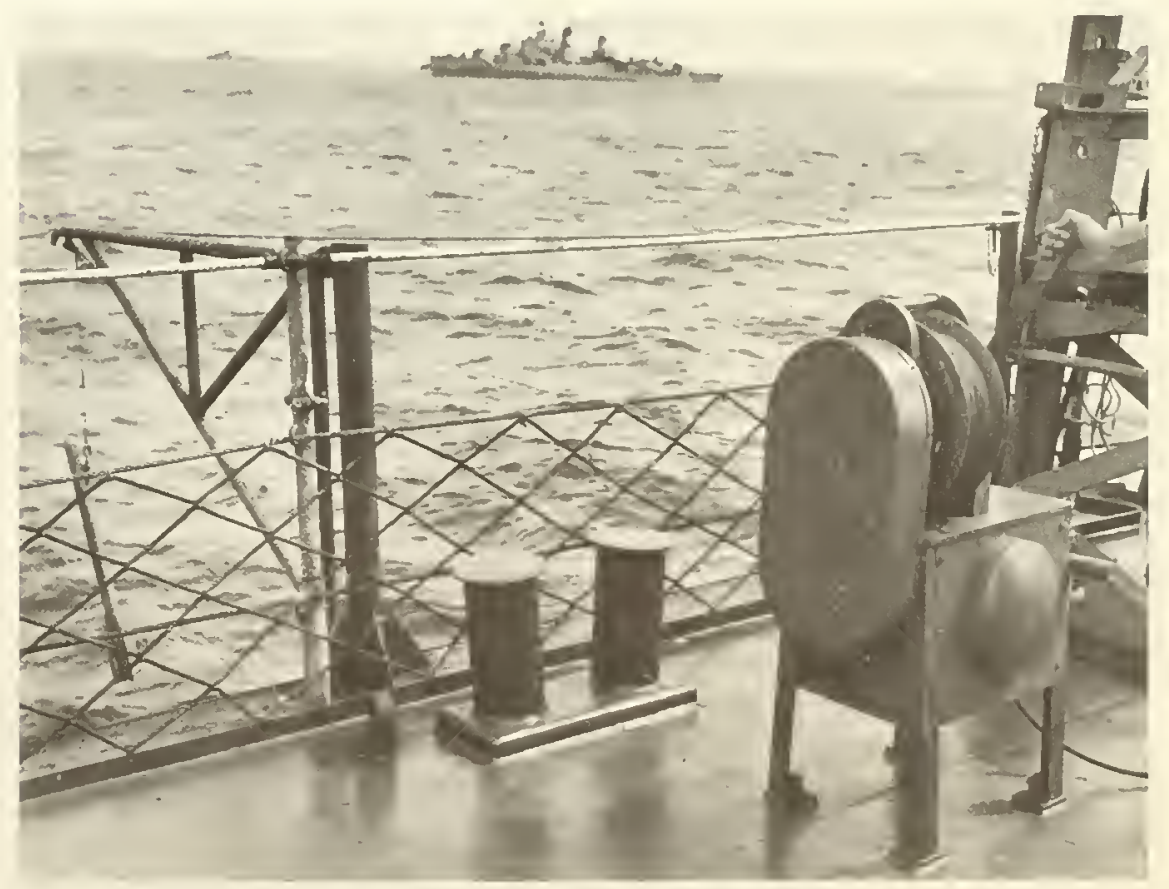

Bathythermograph makes quick record of temperatures at different depths. Data are useful in finding fish. 


\title{
The Future of Fish Harvesting
}

\author{
by Basil A. Parkes \\ President, Boston Deep Sea Fisheries, Hull, England
}

I have made every endeavour to keep this paper strictly to the subject of the harvesting of fish in the seas. I have found this more than a little difficult for, as in farming, harvesting is affected by all the other aspects of husbandry. It is a segment of a cycle of interrelated activities which can be separated only with some arbitrariness and artificiality. I know, therefore, you will forgive me if at times, in the interests of realism, I stray beyond my authorised limits. (It is perhaps a characteristic of fishing industries the world over to regard limits of all kinds as things to be strayed over from time to time!)

My remarks are largely concerned with the North Atlantic. Moreover, I speak as a practical man operating fishing fleets in the light of a commercial profit and loss account and in the perspective of a company balance sheet. You will I hope forgive me, therefore, if my observations remain on a more mundane and somewhat less joyful level than those whose sweep-from the point of view of geography, criteria and time-is much broader and whose analysis leads them to speak reassuringly of the prolific promise - a new Garden of Eden - that the world's occans hold out to the seething billions in generations yet unborn.

I will begin by indicating briefly the types of fishing ressels which Great Britain and many of our European neighbours are using in the North Atlantic in which I include the North Sea and Arctic waters.

We have a large fleet of roughly 1,000 Seine net fishing vessels, ranging from $45^{\prime}$ to $80^{\prime}$ in length. Most of the vessels are built of hard wood powered by engines ranging from $100 / 200$ horsepower. A large proportion of these vessels are operated from Scotland and are mainly Skipper and family owned. Most of these vessels are not operated in the same manner as the Danish Seine netters; they do tend to tow their gear after the trawl and the Seine net ropes have been shot. This is a type of fishing that has expanded very greatly since the war and is being successfully operated. This type of mainly inshore fishing vessel should derive considerable benefit from the new limit lines after they have been in operation for two to three years.

In most of these countries, the trawling flcets are divided into four main types: Firstly, there are the near water trawlers. These lic within the range of about 90 to 120 feet overall; 22 to $24 \mathrm{ft}$. beam, with 10 to 12 feet moulded depth, gross tonnages range from 150 to 200 tons and horsepowers from 300 to 500 , giving speeds of 9 to 11 knots. These vessels operate in the North Sea, the Irish Sca and the other waters fairly near to the coasts of Great Britain and the other maritime European countries.

Secondly, there are middle water trawlers which in length range from 120 to 150 overall; 25 to $29 \mathrm{ft}$. beam, with 12 to 14 ft. moulded depth, gross tonnages range from 200 to 450 tons and horsepowers from 700 up to 1200 , giving speeds of 11 to 13 knots. These vessels mainly fish in the deep water grounds of the Continental Shelf on the West and North of Scotland, at the Faroe Islands-or rather on the few grounds that still remain open to us there - and also on the grounds around Iceland.

Thirdly, there are distant water trawlers. These rangc from about 150 to a little over 200 feet overall, with a beam of 28 to 33 feet, tonnages ranging from 450 to 850 tons, with speeds varying from 12 to 15 knots. They spend most of their time fishing at Iceland, Norway Coast, in the Barents Sca, Bear Island, Spitzbergen, Greenland, and occasionally the Newfoundland Banks and Labrador. Very few distant water trawlers have been built during the last three or four years as owners have been considering the economics of stern-fishing freezer-trawlers.

Britain now has 7 such stern-freezers operating (apart from the 3 Fairtry factory trawlers). One of these, the first freezer trawler to be built in Britain, freezes only the first part of its catch; the last 150 tons caught are brought back packed in ice in the traditional way. But no more hybrids of this kind are likely to be built. The remainder of the stern-freezers, and there are a further 15 or so now being built or on order, are designed to freeze all their catches as gutted whole fish, sometimes headless but never filleted or processed in any way.

However, most if not all of these freezers have been designed with the possibiiity in mind of installing a filleting line, and a small fish mcal plant for the offal, at a later stage if circumstances warrant it. The dimensions of these ships vary from 210 to 250 fcet overall, 36 to 42 feet beam, 16 to 24 feet moulded depth, with powers ranging from 1500 to 2500 horsepower and speeds from $131 / 2$ to $151 / 2$ knots. Some are diesel- 
electric and others are direct driven with a single engine. Most of the vessels are capable of freezing daily 24 to 30 tons of whole fish.

The great problem concerning this class of vesscl is whether there will be enough fish in the North Atlantic to enable these ships to work profitably. Or rather, whether there will be enough of the varieties demanded by a British public that has highly conservative tastes. We estimate that we must catch a minimum of 12 tons a day while on the fishing grounds before these ships break even. Some of the ships of other European countries differ from ours, partly because they are fishing for a public with different tastes and hence are fishing different stocks. Nevertheless the stern-freezer that I have described is not peculiar to Britain and may be found in France, Belgium, Holland and West Germany, save that most of the freezers used by Western Germany fillet their fish at sea rather than freeze it whole or headless.

There are, in addition, on order in the U.K., for delivery later this vear, three small factory trawlers of 170 feet in length. Not much is yet known about these, though everyone in Britain is looking forward to their appearance with great interest. It scems likely that we shall soon settle down to a compromise on this issue of filleting or freezing whole: the answer may well be to install no more processing facilities for the production of fish atick blocks and/or fish fillets than those which will be kept, say, at least $90 \%$ employed continuously while on the fishing grounds-despite the inevitable fluctuation in catching rates. The situation will then be that while fishing is slack all the eatch will be processed and frozen but as fishing grows heavier more and more will be frozen whole. This part-and-part system obviously reduces greatly the extent to which costly labour and equipment stand idle-as it must do in a full factory trawler handling fluctuating catches. At the same time, such a system reduces the size of the ship required for any given level of catch. Clearly, however, some nice calculations are required here.

Photographs in this article show each class of ship operated by Boston Deep Sea Fisheries, Lrd.

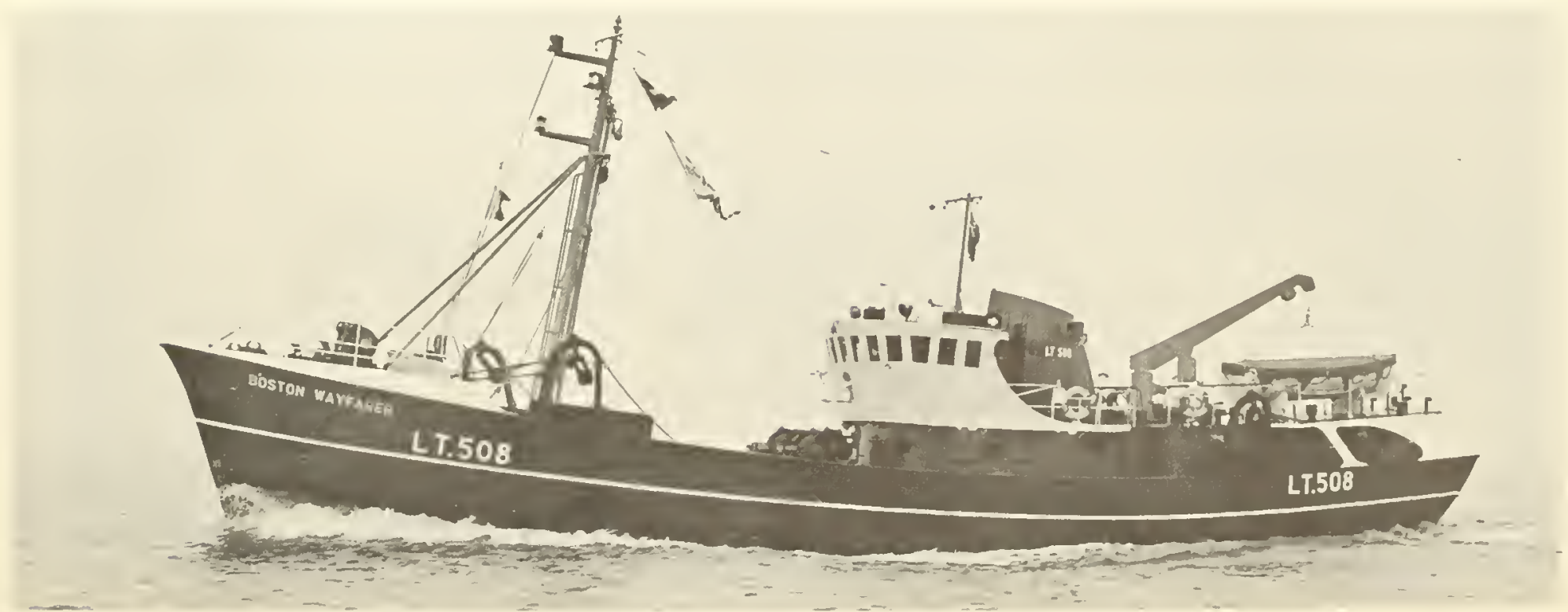

102-foot, near-water trawler $M I V$ Boston Wayfarer operates in North Sea. This class seldom goes over 150 miles from home port. 
It is still an open question whether a really large factory trawler ought to operate with a number of satellite catchers. We have in Britain done some research into the most appropriate means of transferring catches; maintaining quality is an important point here and much has been learned from the commercial trials that have already been carried out. But result. so far have not been encouraging. Consideration has also been given to a rotating mother-ship sistem whereby, say, six trawlers transfer all their catches to a seventh which would soon depart for home with a full hold of high quality newly (aught) fish stowed in ice in the traditional way. One of the remaining trawlers would then assume the role of mother-ship and its place as a catcher taken by a newly arrived trawler (and so on). Some high level paper studies were made on this question but, even assuming satisfactory answers to the technical problems, conclusions were not optimistic.

The word "harvesting" is very expressive. But I am not sure that "hunting" would not be more appropriate, particularly when applied to the North Atlantic. On all the known fishing grounds in this region it is becoming increasingly hard to find a commercial quantity of sizable and edible fish of the types in popular demand. Many grounds around the coasts of Europe which were prolific thirty years ago are now commercially barren. We all know that the main reason for this is overfishing and the failure to take the necessary precautions to allow small fish to pass through the nets. I realise that I am straying into the field of conservation. But there can be no worthwhile hariest, at least in the longer term, if there is not good husbandry.

Good husbandry means simply economic management. In the North Atlantic management is virtually absent. But fishery scientists have sounded the warnings. We in Britain sincerely hope that both of the International Commissions concerned will heed the warnings; there is an urgent task of ensuring that the growing intensity of exploitation is curbed and effectively regulated to maintain fishing vields at commercial levels. We hope also to see helpful developments in the field of international policing and enforcement of agreed measures of conservation and also of behaviour of fishing vessels on the grounds. Our hopes in this respect currently rest on the Technical Meeting of experts held in April this year to examine these very topics. In the past, all International Conventions concerning conservation in the North Atlantic have suffered from, first, a restricted number of signatory countries; secondly, the meagreness of the measures themselves and, thirdly; the lack of effective enforcement in some signatory countries. We hope we are now moving away from these inadequacies.

To offset the increasing difficulties of catching, we have had to initiate research into and to try out new methods, new techniques, and new aids. Most European trawlers are now carry-

MIV Haselbech, 127-foot trawler, fishes mainly on Scotland's west coast, Faroe Banks and, occasionally during summer, off Ireland.

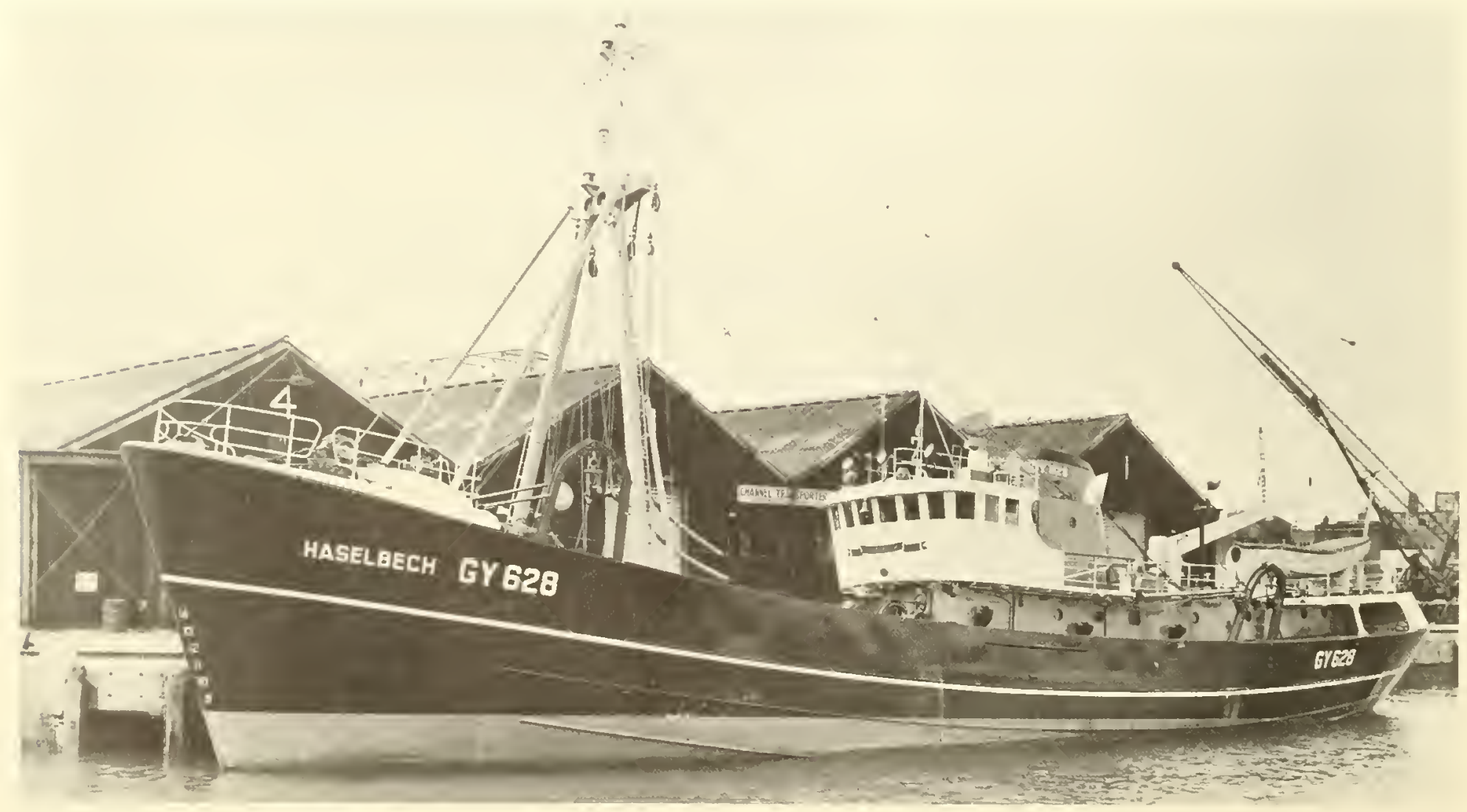


ing at least three sounding devices. At least two of them are usually graph-type sounders, which give not only the depth of water but also a record of both bottom and pelagic fish. Nany of these devices are able to magnify a particular range of depths to enable skippers to see how near the fish are to the botton or how dense the shoal is.

The latest type, the Explorator, is now being used by some ressels but particularly by French trawlers. This gives a reading ahead of the ship at an angle which varies with the depth of water. It swings $20^{\circ}$ to either side of the ship's head. Consequently; if the fish reading is denser to starboard the skipper pulls the ship in that direction to trawl on the heavier fishing.

This apparatus is being tried in the North Atlantic and Arctic grounds but it has not proved very successful so far. This may be because of the greater depths in which we now fish -150 to 350 fathoms. The device has, however, proved very successful on pelagie fishing, particularly where the fish are normally found in shoals.

Most trawlers nowadays carry a speedometer. If, after towing at 4 knots, the vessel suddenly steadies down to $33 / 4$, the skipper, on reading this, will realize that he has a lot of fish or mud in his net-or that he is in trouble for some other reason. He will then decide to haul, lest he loses his gear together with all the fish he has in it. Without the speedometer he might continue towing until serious damage is done to his gear.

British distant water trawlers carry sery powerful radio sets, casily capable of transmitting round the world. They are known as "Globe Span" for this reason. They are fitted for telephony" also. Owners often speak daily to their ships in the Aretic and across the Atlantic to Greenland, the Newfoundland Banks and beyond. A smaller set with a range of possibly 500 miles is usually fitted in addition for ship-to-ship operation. Moreoser V.H.F. is available and private frequencies are allotted. This allows all the vessels within a company's fleet to talk to one another without the ships of other companies listening in. It encourages cooperation within the company. And cooperation is sorely needed, for British fishermen, if not fishernen throughout the western world, tend to be secretive for understandable reasons.

There is a notable exception to this among the skippers of the big freezer trawlers. They appear to have developed an international code of conduct which denands of each one to let all the others know immediately he strikes good fishing and to give his precise location. If he is found wanting in this respect, he is thrown out of the "club" to his own great loss. The exchange of information of this kind is highly important if we are to match up to the extensive fleeting operations of Russia and others.

Underwater television has been tried as a means of fish finding but submarine light penetration in northern waters is often poor. This is due to the density of plankton and other organic matter. Consequently, in the waters mainly used by our ships, this is not a practical proposition.

Most of our ships carry two radars: one capable of at least 48 miles range and the reserve about 25 to 35 miles. A reserve against breakdown is a highly prudent precaution. It is often difficult to know, in the waters adjacent to many countries, where the limit line is without a really good radar. Straight baselines are often drawn, not merely from headland to headland, but from one rock to another in the ocean. As a result, a 12-mile fishery limit may be 50 miles or more from the nearest landfall. In these conditions cross-bearings cannot be obtained. Hence, it is dangerous to fish anywhere near a limit line without a good radar. For similar reasons, British trawlers usually carry two direction finders.

Radar has some rather olsvious additional uses in the narigational field. But it is also very useful for fishing itself. A buoy dropped on the location of good fishing allows an easy return, by the use of radar, if fishing is interrupted by fog for example.

This point was brought home rather forcibly to me when in the early 1950 's I took a trip on one of our newest and largest trawlers, with my eldest son and my nephew Tony Wilbraham, who is with us today. It was on that same trip that I decided never to have any crew positioned forward on any further trawlers built by ny Company. I saw too clearly the difficulties in bad weather of the men getting from their living quarters to midships for their food, and again going on watclı. All our ships since then have their crews positioned midships or aft; they are able to get to the wheel-house or engine room without going on to the open deck at all wlien on passage.

I also decided on that trip never to have the wireless operator sleeping in the wireless room. I found that the skipper would not go into it during the early hours of the morning in case he disturbed the sleeping operator. This was nonsense. The skipper and the mate should have full access to the instruments in the wireless room at all times.

I have no doubt that there is still plenty for us to learn by going to sea with our ships. But there is also a great deal to be learned by research and development scientists, particularly those in the mechanical and electrical engineering fields as distinct from marine biology. Nowadays such scientists are often to be found on our ships as a result of the new emphasis we have given to research.

We have spent considerable sums on attempts to develop a more efficient trawl. In the process a great deal has been learned about the hydrodynamics of towing a trawl through the water. Indeed, a trawl of a greater mouth area has been devised. But despite all the expenditure, all the expertise, all the pure and applied research, the new trawl has caught no more fish than the old.

Many different types and shapes of otter-boards have been tried but no great change has taken place. As of old, wooden bobbins are still used, though most vessels use mainly steel and rubber. There has, however, been a distinct improvement in net materials. Nost of our nets are made of synthetic fibres instead of manila or sisal. One of our ressels actually made a synthetic trawl last twelve months. These synthetics allow the headline to be lifted a few feet higher with the aid of aluminum floats and sometimes with kites. The drawback is that we fish on such rough ground that we lose a lot of gear. It is not unusual for our distant water trawlers to lose four, five or even six thousand dollars worth of gear in one trip. 


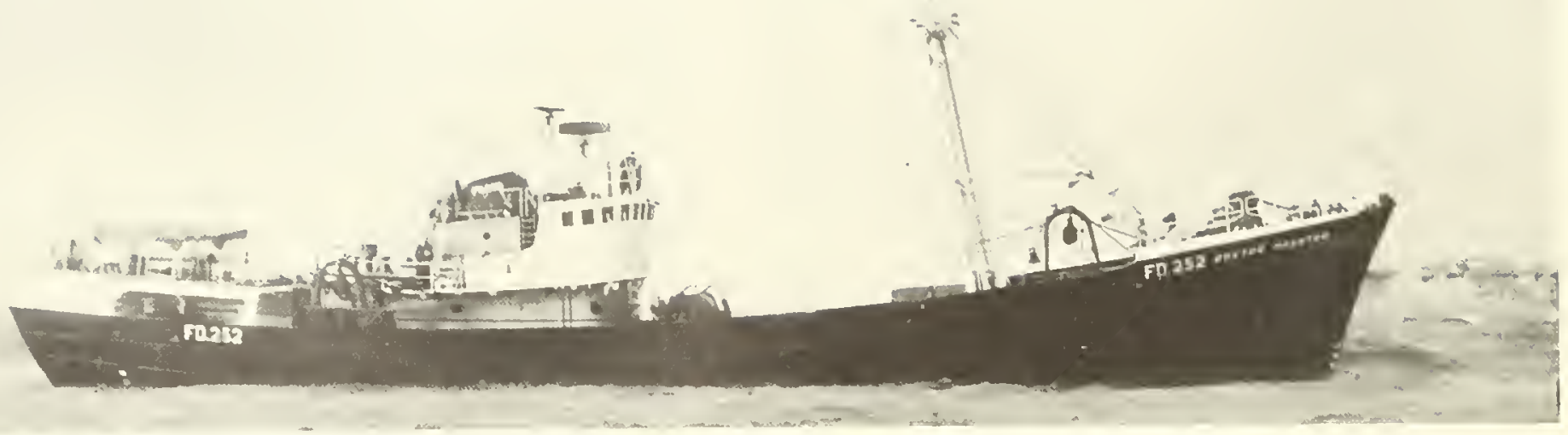

142-foot MI/V Boston Pbantom operates in deep waters off Scotland and Ireland.

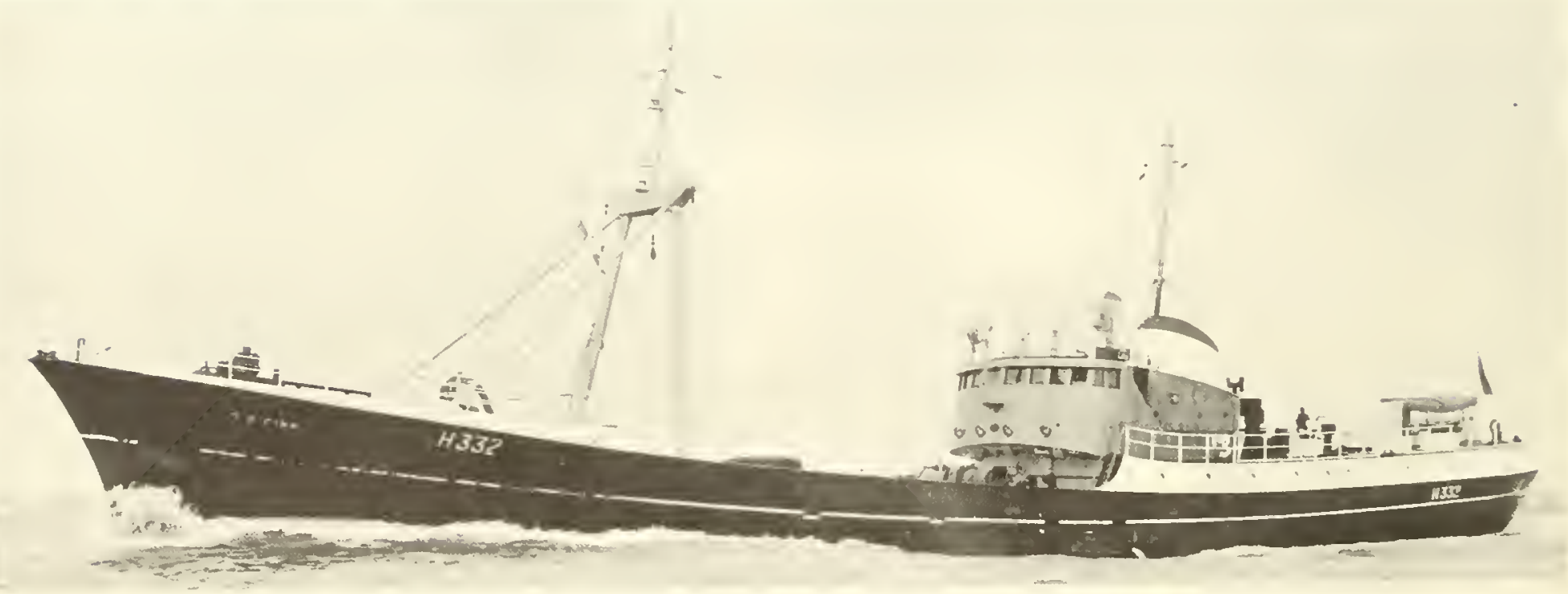

MIV D. B. Finn, 202-foot, deep-water, conventional trawler, fishes Iceland, Barents Sea, Bear Island, Greenland, and all distant Arctic grounds.

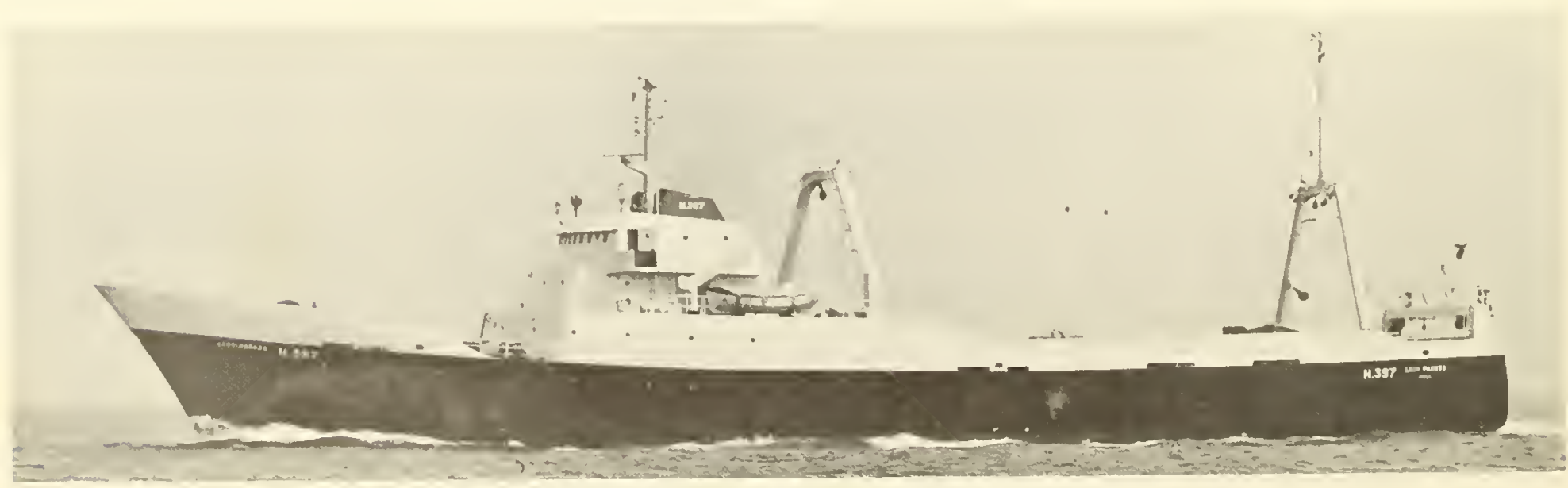

New 240-foot, all-freeze, over-the-stern-part factory trawler. 
The decline in the rate of catch has caused voyages to lengthen. This has raised problems of maintaining standards of quality: Boxing the catch at sea in up-to-date containers has been tricd out on a pilot scale from several trawling ports in the past eighteen months. Much valuable information has hcen gained about the suitability of box design and methods of handling, stowage and landing of the boxes.

A possible alternative method to straightforward stowage of fish in icc, which stops short of freezing at sea, has been the subject of intensive study recently. Known as superchilling, the technique is already in use aboard Portugucse trawlers and the possibility of applying the principlc to British trawlers is being examined. It has long been known that bacterial spoilage, which is slowed down by kecping fish at ice temperature, can be reduced further by lowering the tempcrature of stowage a few degrees below $32^{\circ}$ Fahrenheit. It is now possible to devise fish rooms that can maintain the iced fish at an accurately controlled temperature of about $28^{\circ}$ Fahrenheit, with the result that the useful storage life of the fish can be extended by about a weck.

The possibility of carrying out commercial trials with the new method is being considered, following a demonstration of cxamples of super-chilled fish prepared experimentally. One disadvantage of the method is that the fish are partially frozen at this low temperature and need to be allowed to warm a little, cither just before or just after landing, to make them soft enough for filleting and processing. Another drawback is that there is some loss of textural quality, with slightly increased drip loss on thawing. Moreover, the costs involved are quite substantial so that it might prove more economical to go one step further by installing facilities for quick-freezing instead.

A number of distant water trawlers are now carrying some antibiotic ice for fish stowage as a means of extending the shelf life of the earliest-caught part of the catch.

Research into all aspects of freezing at sea is continuing apace. Experimental work is now being concentrated on improving the design of freezing plant for use in these vessels and on further development of a number of types of thawing plant for use on shore to handle the frozen catches coming in.

Research is also continuing on the problems associated with the freezing at sea of fish fillets. Because of problems of rigor mortis, these do not behave during freezing in quitc the same way as whole fish if the fish are processed immediately after catching.

As a result of an extensive series of measurements taken during normal operating conditions, a much more comprehensive picture is now available of the exact requirements of the trawl winch and main propulsion systems of stern-fishing freezcr trawlers. These investigations also led to suggested changes in operating practice that should lead to useful savings in time, fuel and wear and tear on fishing gear. They also show the need for improved winch brakes and controls as well as the desirability of instruments to indicate to the skipper the tension in the trawl warps. Prototype warp meters have heen installed for trial in two vessels already and the skippers have been enthusiastic in their reception of this new fishing aid.
The British Fishing Industry has recognised that the taking of measurements of the kind just described in commercial fishing conditions can form a sound basis for the development of improved ships and equipment. For this reason scveral owners have provided permanent facilities for research workers in their new ressels. The study of the speed of these ships in a seaway as compared with measured mile performance and the recording of stresses, motion, fuel consumption and other factors affecting costs and performance have begun--using automatic recorders and cxperimental data loggers as well as human observers. Moreover, work is now in hand to develop a system by which the skipper will be continuously informed of net spread, headline height and other matters concerning the trawl and its behaviour when being towed along the sea bed.

We in Britain are far from alone in giving this added emphasis to rescarch and development. The pce of technological change is quickening throughout the fishing industries of the world and there is now a much greater interest in finding out what the other man is doing. I am confident, therefore, that we can look to continued improvements in gear and methods of fishing. But all such improvements merely add to the intensity of fishing that is already increasing rapidly with the growth of the Japanese and Communist fishing fleets. While nothing must be done to arrest or slow down the rate of economic progress, we must not let this lead to our nuin the international control of the fishing intensity together with other effective measures of conservation and international means of enforcement are imperative if commercial fishing industries are to continue making their contribution to the satisfaction of growing world demands for protein.

Undoubtedly there are many areas of the sea which are virtually virgin. The east coast of South America readily springs to mind, but there are difficulties in establishing shore bases and factories in some countries in that area. Again, there are many prolific grounds in the Arabian Sea and the Arabian Gulf but the varieties of fish found there are not those to which our consumers are accustomed. We may be faced, however, with the need to reeducate the public. In any event, much more needs to be done to explore and to assess the value of fishing grounds the world over. While the intensive fish farming of inland lakes may provide a long-term answer to increasing supplies of certain varieties on a commercial basis, it must be the world's oceans that continuc to provide the bulk of the world's fish supplies.

Let us hope that our effectiveness as fish killers does not for long continue to outpace our effectiveness as fish conservers. The present disparity between the two unfortunately finds its reflection in this paper. I cannot pretend to have said much on harvesting proper; my emphasis has been on more efficient means of tracking down and killing our quarryon improving our prowess as hunters- while adding my cry against the consequences of our actions. I trust that those who at this Conference are concerned with conscrvation can hold out the prospect of an early redress of the situation-a transformation of hunting into husbandry, of a kill into a harvest - where we can all boast of being at work, as at home, good husbands! 


\title{
"Processing-Tomorrow"
}

\author{
by E. Robert Kinney \\ President, Gorton's of Gloucester, Inc.
}

The developments in science and technology have shortened the time required to effect new ideas and new processes to produce new products. Technological change is obriously one of the most dynamic forces at work in the world today. Wc have in the United States of America more than 800,000 engincers marshaled to provide us with the greatest creative force ever availablc.

In the old days, rescarch and development was a leisurcly thing. A man worked alone or with a few assistants. The time factor was not an important one. Remember, Newcomen's demonstration of the steam engine preceded the first commercial railroad line by more than 100 years.

Today, scientific information has been doubling in rate every 10 years since the year 1200 . Today, we begin to feel the effect of it.

While other generations and other civilizations in the past had wonderful science and geniuses, none of these found it possible to utilize their science so effectively on behalf of their population. This utilization factor or conversion of science to productivity, via engineering advances, integrated with the compression of time, is something that characterizes our age today and makes the art of prophecy of the future of this industry fraught with difficulty and questionable reliability.

I was asked to talk with you about my prediction for the futurc. I am willing to do that because by the time the future comes along what I have predicted won't matter because I won't be here with you then. I may not be here at all by that time and you certainly will have forgotten what I said. It is one of the safest occupations in the world to be a prophet.

Nevertheless, inspired by this group, I will attempt a transformation and metamorphosis from the prognosticator to the prophet. I would guess that this is the same order of transformation as the comparison of a man running a business simply by the seat of his pants a's the modern orderly executive armed with an executive staff and a computer.

What are some of the problems that face us? What are some of the solutions we might see in bare outline for the future? What are some of the products which we might expect in the marketplace?

First of all, we must recognize that man has becn producing babies at an awesome rate! The daily population increase of
140,000 souls would make a line from London to New Zealand in 1 year, passing a single ration point; and, if we think of the extra mouth as a refugee receiving a meager ration of a pound of bread, $1 / 2$ pint of milk and $1 / 2 \mathrm{lb}$. of fish, this means $21 / 2$ million cxtra cows and 10 times the total catch of the Icelandic fleet.

It has taken mankind over 200,000 years to reach the present figure of 3 billion people. At the present rate of increase that figure will double itself in 40 years.

Now these are statistical facts. They prove that either we have more comfortable beds, cars, and other means of procreation, or that our infant mortality is less and our life span is greater. Neverthelcss, all of us in the food industry must recognize that the geometrical rate of rise in our population is one that can affect us in our industry--not just tomorrow, but today. For example, we have more and more people who are fishing for food in the North Atlantic. These create tremendous problems of raw materials that need to be solved. We must become more cosmopolitan and less provincial than heretofore in our fish supply.

We believe in an incongruous world today, full of paradoxes and imponderables. On the one hand, we think nothing of sending space shots at $\$ 10$ million per shot and, on the other, we argue in the Congress about spending $\$ 500,000$ per year on the United States fish flour program for the hungry bellies of the world. Throwing instruments or men into space costs about $\$ 50,000$ for $1 \mathrm{lb}$. of weight. This gives you a bare idea of the paradox. Our fish flour program represents the cost of sending about $10 \mathrm{lbs}$. into space!!

Now, by this I do not mean that fish flour will be the caviar of the two-thirds of the world that goes hungry each day. Not at all! I believe that people are and will be interested in foods as foods. Steaks and cakes-foods that their particular civilization and babies are accustomed to.

Thus, we today know that proteins need not be animal in nature to begin with. They can be from plants and these plant proteins can be spun as fibres, woven as clothes, and made into steaks with all the flavor and texture of the natural product.

I am not suggesting as fishmongers that we necessarily go into this. But I am suggesting that we be aware of these de- 
velopments and be prepared to participate for the good of mankind, as well as for the future of our industry. Remember, we live in a satellite-encircled planct of which only thrce-tenths is land and, of that three-tenths, only one-tenth is cultivated. Seven-tenths of our earthly planet is water and our industry gets its raw materials from the greater potential in this world.

Now, I would like to direct our thoughts to another aspect of the increasing problems that face our industry - that of the well developed countries such as the U.S.A. These problems, as I sce them, are based on the fact that each American consumes, on the average, about 2,500 calories per day, total. This represents about 912,500 calories per year. Now, he may be able to purchase and use 3 television sets, 3 cars, 4 cameras, 6 suits per year but, in terms of foods, he can only utilize 2,500 calories.

The entire food industry must compete for these 912,500 calorics annually. At 10 lbs. per capita annual consumption of fish, this represents only 5-10,000 calories! About $1 \%$ !! We, as an industry, must compete better. We must capture more of the food dollars. We can do this only at the expense of another segment of the industry. And ... we had better compete more successfully in order to survive. We can do this by:

a) Improving our present products

b) Developing new products and processes

c) Controlling and reducing labor costs

d) Recognizing the market of convenience

I firmly believe that, as an industry, we must not rest on our laurels. We do have somc poor products in the marketplace today and we should recognize the fact and improve these. We will be judged in the marketplace, usually, by the poorest quality products, at the very best, by the average of the inclustry, and never by the best products. Thus, we must upgrade the products now being produced by our industry in order to try to get more of the consumers' food dollars.

I also firmly believe that we must becone increasingly more imaginative and creative in our efforts to get the consumer to purchase more seafood products. Creativity is a phenomenon peculiar to man of all the animals. Our sister industries of steel, electronics, aerodynamics, etc., have put a tremendous premium on creative thinking. We must do the same. We are in a highly competitive economy in the food industry. Daily, new products appear and old ones disappear. We, too, must find ways of creating new products, of developing new processes to achieve better quality products at lower prices to the consumer. We must snap up each morsel of discovery of the scientist and transform this, whenever practical, to our own industry and its products.

Perhaps the three best examples I can cite relate to irradiation of seafoods, freezing with liquid nitrogen and freeze-drying. Now, I am not advocating that each of you should go out and sell your mechanical refrigeration plants or junk your canning lines. Rather. I am suggesting that we all take a cold hard look at each of these methods and dream of what each could do for our businesses. This is creative thinking and is one of our most vital resources. We depend on it for our industrial advancement. It is a mercurial and ephemeral disposition of the mind - it is virtually impossible to measure quantitatively, and the best we can do is count the evaluation of new, basic concepts to apply these technological advances. I have cited three. I do not expect these to replace ranning or freezing preservation of marine products. But, I do belicve that cach of these processes has certain inherent characteristics that we can and should utilize.

Irradiation can destroy bacteria and can extend the refrigerated storagc life of marine products. Let us look at this phenomenon objectively and pursue it to see whether it will provide better fish products for consumers in certain parts of the interior of this country, and whether it will do it at an economical price. Let us study it in the light of our own deep knowledge of our own industry and our own businesses.

We know that lyophilisation, or freeze dehydration, too, can produce certain kinds of products. Let us determine whether this can fulfill a consumer demand with excellent profit to our industry: We know that liquid nitrogen does modify the structure of foods by the rapid rate of cooling. Can this produce products not possible by normal means? What are the costs?

I believe that our industry spends little enough on true research. Oh, I know, we all say we have research budgets, but into these we throw quality-control, firefighting, etc. What we really have is "science of emergency." At the very least, let us spend a little money and evaluate carefully the developments made possible by the research effort of others. This we owe to our stockholders, much less than to the public.

I am sure that the success of our industry in the future is to a large extent dependent on our ability to alleviate increases in labor costs.

It is obvious that, in order to decrease labor costs, we must increase production efficiency. This is an absolute necessity if we are to maintain the present level of consumption of our products, much less to increase the utilization of the "fruit de mer."

The sixty-four dollar question for all of us is "how to achieve this?" Now, I believe that our industry has shown, by the actual history of consumer prices of seafoods, that in spite of labor increases we have been able to maintain only modest increases in prices of our products in the marketplace. This has been done only through automation and production efficiency achieved through design and construction of new efficient equipment which can reduce labor costs, reduce losses, increase production efficiency and improve product quality. Were any one of the companies represented here as efficient in their production practices 10 years ago as they are now, wc would have been making barrels of dollars then.

It has been said that "those who ignore history are doomed to repcat it." Thus, I say to you, look at the future as a mirror reflection of the past. Look to more automation as a means of maintaining price levels. Let us, too, look at computer technology as a means not only of inventory control and billing, but production control as well. As I gaze in the crystal ball I cannot but see the aggressive part of our industry running their production lincs with computers. Automated filling and dispensing equipment controlled by computers will be used to make fish products with uniform formulation, texture, color and 
flavor. This, I belicve, is an avenue open to those of us with rision, imagination and perspicacity. To some of us, I believe this is an a priori means to maintain not only survival, but to achieve growth. This, I believe, is a pragnatic approach to automation and seafoods.

Lastly, let us learn the positive attributes of our products and let us retain these in our processing and distribution, and let us maximize these positive attributes in our marketing.

Seafoods, fresh from the ocean or lake, are full of flavor, wholesome and nutritious. Let us spend a little more time, money and research effort into retaining these positive qualities given us by nature and, together, spend a little more money in convincing the consumers of these attributes of our efforts to give her more product, more convenience, more nourishment and more flavor. Let us remind her of how these developments can help to make her an international chef in her own kitchen and transform her kitchen into a cuisine. This is a far better and more positive way of our spending our stockholders' dollars than in undercutting each other by delivering products of inferior quality.

Research and development, creativity and imagination in processing in our industry synergistically can result in a positive force for improved products, new products, new processes and more profits.

I know research is a gamble. But do not quit easily. You cannot conduct it according to the rules of efficiency engineering. If you don't know what kind of research to do, get someone who does. First of all, don't rely on committees. In my' experience, committees are wrong most of the time and committees of company vice presidents are wrong all the time.

Disraeli once said, "Every production of genius must be a production of enthusiasm." Be enthusiastic about fish processing and its ultimate rewards to you and to your stockholders. It will cost you money just as seed does to the farmer, but you will get back your seed monies many fold. In our competitive economy for the consumers' dollars, we cannot remain still or idle for, to do so, in actuality, is to move backward-and moving backward is never at a steady rate, but rather at an increasing one.

We are fortunate as an industry to be able to ride on the shoulders of the results of the research of our sister industries. If we maximize this by actual doing instead of talking about it, the rewards to us all as an industry may be great indeed. There is an old saying to the effect that "the world steps aside for the man who knows where he is going." Do you?

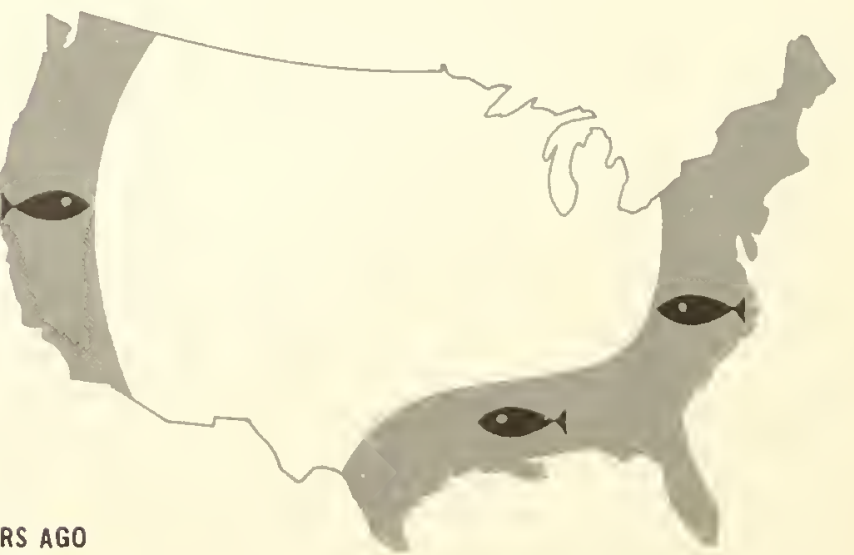

15 YEARS AGO

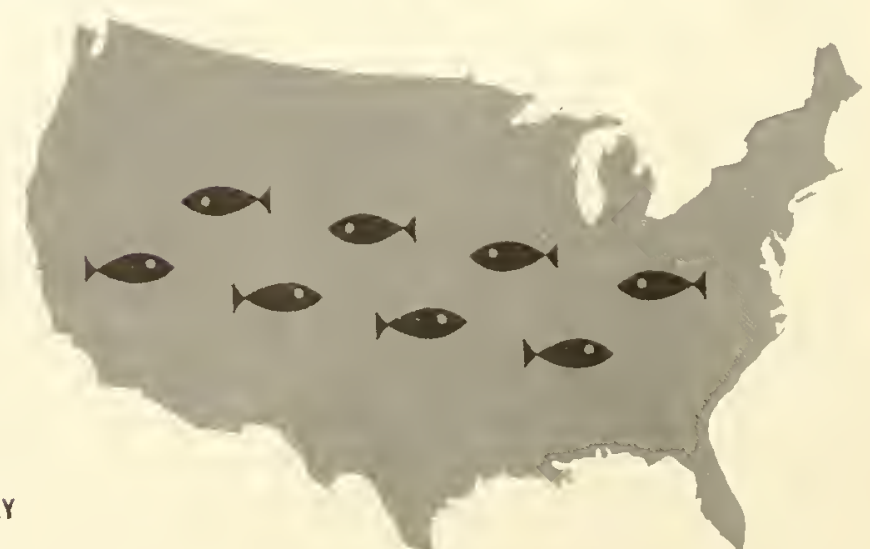




\section{A Panel Considers: "Sell up to Higher Profits"}

Arthur H. Frohman

Chairman, Fish 'n' Seafood Promotions Division, National Fisheries Institute

JOHN MEHOS

Iice President, The Liberty Fish EO Oyster Company, Galveston, Texas, for many years a leader in the shrimp industry and one of the founders of the Shrimp Association of the Americas.

Eric Turnill

General Manager, Fresh and Frozen Division, B. C. Packers, Ltd., Vancouver, British Columbia, and active in the Fisheries Council of Canada.

Dr. Wendell Earle

Director of Programs and Food Distributing, Cornell Lniversity, Consultant to Jewell Tea Company.

Arthur Frohman: The fish and seafood industry, America's oldest industry, has gone through radical changes in the past dozen or so years. Many of our products which are commonplace in stores and restaurants across the nation today were not even known twelve or fifteen years ago. Fish sticks and portions, just to name two.

All this, plus changes in the sources of our products, have resulted in revolutionizing our industry. We are today a national yes, an international-marketing industry. It is for this reason that we have planned for this session a panel report designed to do three main things:

1. Analyze the industry as it is today from a marketing point of view, in contrast to a dozen years ago.

2. Project our thinking into the future insofar as marketing is concerned.

3. Present to you our thinking in terms of marketing potential and profits for the industry, if we but take advantage of the opportunities which are ours.

All three of these areas have tremendous scope and reach, and the task our panel has undertaken is therefore a difficult onc. However, I believe you will agree with me when they are through that we picked panelists who are thoroughly competent and who have the vision and knowledge to do the job.

John Mehos: My part in this report is to illustrate the remarkable changes which have taken place in our industry during the past ten years or more, insofar as consumer products go. In doing so, we are not forgetting the fact that markets for fish and shellfish are developing in other countries-in Europe, for example-but we are concerned here, today, only with the United States.

As Mr. Frohman pointed out, we have gone through something of a revolution in the fishing industry during the last ten to fifteen years. At one time, the bulk of our products was marketed on the sea coasts. Relatively little was sold in the middle of our country, where most of the population was still not aware of the delicious products available to them.

Today that is all changed. From one end of the United States to the other, a wide variety of fish and seafood items is found on menus of hotels and restaurants and other mass-feeding establishments. American homes far from the Atlantic, Pacific, the Gulf or the Great Lakes can select from any number of products in the freezers, on fish counters of supermarkets and other grocery stores. Yes, we are truly a national industry today.

To illustrate this: The dramatic increase in the rctail value of fish and shellfish products is highlighted when we recognize that today this yearly value is $\$ 1.3$ billion, whereas ten years ago it was $\$ 900$ million. This is an increase of $\$ 400$ million or 44 percent, an increase of nearly 5 percent each year.

On the face of it, this increase in dollar value of our products sold sounds fine, but we need to take another look. During this same period, the expenditures for all food products increased 60 percent, an increase half again as much as the increase in expenditures for fish and seafood products.

Still another point we need to keep in mind. Between 1953 and 1963, the population of the United States rose from 160 to 190 million people, up about 20 percent, which is partly responsible for our increase in fish and seafood sales.

The Bureau of Commercial Fisheries shows total supply just about keeping pace with population increase. Our total supply of fish and seafood, including domestic catch as well as imports, just about kept pace with population growth.

Another change is the source of our raw materials. In 1953. about 68 percent of our edible products came from waters 
immediatcly adjacent to the United Statcs. Today, about 50 per cent is imported. In other words, hall of our raw materials is importcd-from Canada, Mexico, Norway, Iceland, India, South Mrica, etc.

The value of these imports has gone up correspondingly: In 1953, the Government placed it at about 200 million dollars. $1_{1}$ 1963, imports were valued at $\$ 400$ million, an increasc of 100 percent.

To illustrate this change with a specific product-shrimpwith which I happen to be personally familiar. In 1950, the United States and Mexico produccd amost all the shrimp consumed in the I'nitcd States. Today, 20 percent comes from over 48 other countries.

Now let's look at perhaps the most far-reaching aspect of the changes in our industry-the forms in which our products come to market.

Originally, the American houswife bought our products at the fish counter, packed and shipped in ice or cured or canned. And then something happened. First, Frozen Fillets and then Fish Sticks made their appearance, and the world of fish and scafood really started changing. In 1953, there was marketed a grand total of only 7.5 million pounds of sticks. Contrast with this 1963, when 79.2 million pounds wcre marketed, an increase of almost 1,000 percent in just ten years. Fish sticks had caught on-and were to be followed rapidly by portions and other convenience products.

In 1950, the Breaded Shrimp Industry marketed 61/2 million pounds. By 1964, sales of this convenience food had grown to 81 million pounds - an increase of over 1100 percent-another industry success story.

Thus you begin to see what has taken place-imports in ever-increasing quantities to supplement domestic catch, and exciting new products being created and marketed for hungry millions, many getting acquainted with our products for the first time.

There has been another radical change in marketing - the way and place the American housewife shops for food.

In the early 1950"s, she did 50 percent of her shopping in "old-fashioned" grocery stores-- where she was waited upon by a clerk. In 1963, 92 percent of the total volume of food sales was handled through supermarkets and similar large sell-service stores.

In 1963, in other words, so-called "impulse buying" was well established. The housewife went into her supermarket and picked fishery products from frozen food cabinets.

From this analysis, I think we can conclude that there has been a revolution in marketing fishery products in rccent years and that the old days have gone forever. But we should not, every thing considered, relax and feel that we have nothing to worry about. And so, what about the future? Eric Turnill will tcll you something about this.

Eric Turnill: John Mchos has given you the more significant changes in our industry orer the past few years. I wish now to speculate on what our industry should be prepared for in the next ten years, using as a reference projections and studies made by Mr. Arnold Johnson, Senior Economist, J. Walter Thompson Co.
The postwar revolution in retailing food products has been a creditable expcrience, providing the consumer the means to buy efficiently and relatively inexpensively compared with prewar ycars. The food industry has kept pace and, indeed, in some instances has pioneered new distribution and retailing methods. I believe our industry has more than played its part. I think it creditable that while we may, on occasion, have complained about relatively small per-capita consumption of seafoods in North America, that we did initiate the frozen food revolution and the development of prepared foods. This is very likely to provide us with cven greater future challenges. Firstly, let's consider the market. While my references are specifically the United States, I am sure that a parallel exists throughout North America.

The Amcrican population is increasing as a result of natural increase as well as immigration. This is taking place at the rate of about $21 \%$ per year, or 4 million people are being added to the American consuming population each year. In tcrms of fish and seafood, this represents about 40 million pounds of new sales every year. The population of the United States in 1965 is estimated to be 190 million. In 1975 it is likely to be 231 million, an increase of $21 \%$. This, of course, demonstrates clearly that we will have available then an additional market of over 40 million people.

There is, ol coursc, another significant feature about this market-the American consumer will have more money. Our authority expects that the basic income of the American family will increase $25 \%$ between 1965 and 1975. Even more significant than the expected increase in basic income will be the amount of money per family above the bare necessities. This so-called spare money will increase much more rapidly than basic income. In fact, the average family will have an estimated $98 \%$ more "discretionary spending money" available in 1975 than in 1965. I think it inevitable that competition for this money will be more intense and, therefore, we must be more aggressive in our marketing and merchandising approach. Again, the American consumer will likely buy better food, more sophisticated and higher priced foods, and foods more nutritious, healthful and convenient; more prepared seafoods, shrimp, lobster, halibut, salmon, etc. Estimates of Government and industry say Americans will probably spend $75 \%$ more for food in 1975 than now.

Here is what this means. Today, the American lamily spends $\$ 1,034.00$ for food eaten at home. In 1975, this figure will be $\$ 1,809.00$, or an increase of $80 \%$. Also the American consumer will spend $70 \%$ more for food consumed away from home-at hotels, restaurants, clubs, drive-ins, etc.

The circumstances or the conditions under which the consumer will buy will tend toward automatic and almost completely self-service. To meet this, the requirements of preselling will have to be emphasized. Competition from other foods and demands on the consumer's income, together with the continuing trend of removing the consumer from personal contact, will require aggressive promotion and, above all, education of the consumer to the advantages of fish and seafoods. This must be a continuing program. It is not self perpetuating. Each generation of consumers has to be educated. We 
would do well do demonstrate such basic principles as handling, buying, preparation, and value.

Can our industry meet this anticipated growth. According to the Burcau of Commercial Fisheries, 4.3 billion pounds of landed fish were marketed in 1963 for human consumption. In 1975, the Bureau estimates, we will likely have well over 5.6 billion pounds of fish and seafoods. The Economic Council of Canada estimates the growth of the Canadian Industry at $3 \%$ per year to 1970 , a growth of over $30 \%$. In summary then-

(1) The size of the American market will increase 25\%,

(2) Americans will have $75 \%$ more money to spend on food, and

(3) Our industry is likely to hase $30 \%$ more product to upply this market.

Our role in the next 10 years can be accomplished more successfully and profitably by projecting and upgrading our image more directly to the consumer by this process of education. We have more to tell of interest and have potentially a more fertile field from which to draw our story. This should not only allow us to proride for the future growth and expansion of the industry, but to increase as well the per capita consumption of fish and seafoods. We can accomplish this through fundamental principles. The first requirement is that our industry act in concert.

IV endell Earle: How many remember the general store of a generation ago? I was fortunate to live at a time when a Saturday night trip to town was a major business and social event. Travel was by horse and buggy or sleigh. Impossible, but remember that plowed winter roads did not come to northern Vermont until the 1930's. The village store was the town meeting place with its wood-fired, pot-belly stove, handcranked, red-wheeled coffee grinder, open barrels of crackers,

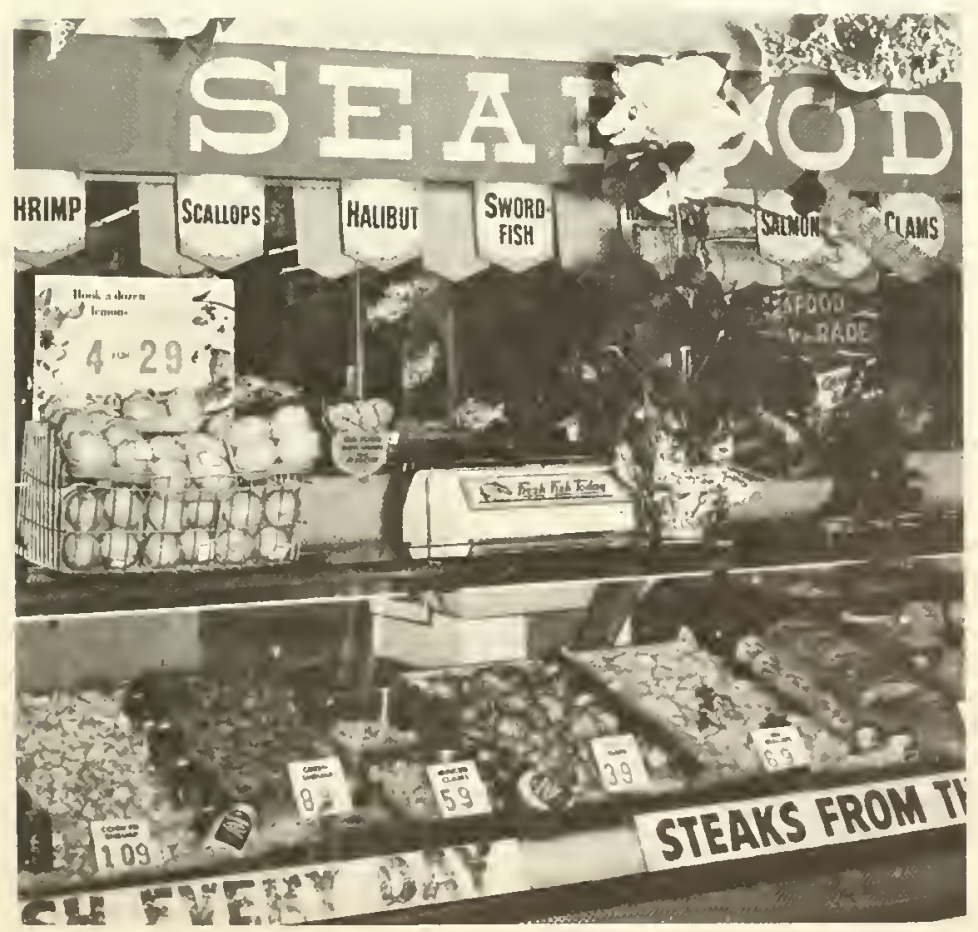

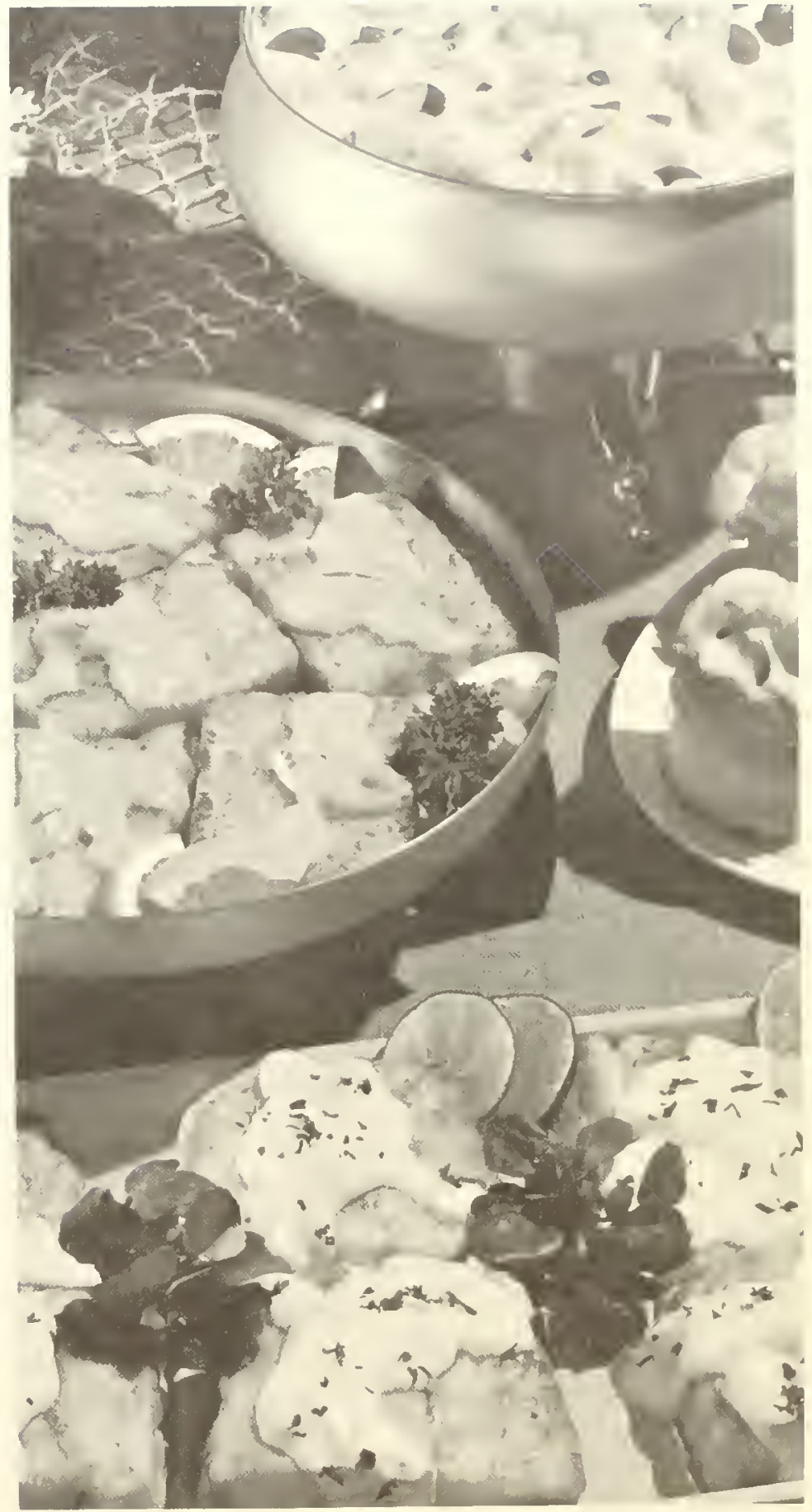

pickles and pork, bolts of cloth, harnesses, bulk peanut butter and penny candy. Most of these country stores, some persisted until the 1940 's, also included the local post office. In fact, they are not yet extinct. If you travel through some of the high hill country off the main highways of New England, you will still find the last vestiges of an early era of food distribution. Those of you who did not have the opportunity to sit on the fringes of a Saturday night's gathering around the red hot stove, missed a part of Americana that has almost gone

There is almost an embarrassment of riches in seafood departments. 
the way of the carrier pigeon. Some of our museums have attcmpted to duplicate the physical facilities, but the aromas, the vigorous discussions, and the chance to eavesdrop at the clbows of the villages' leading citizens have been lost forever.

Ithough many of us now look back with fond memories of the "good old days," we frequently forget the severe limitations in the variety of our food supply. I need go back only 30 years to recall that oranges were expected only once during the vear-in the Christmas stocking. Chicken was a Sunday luxury and often none too tender. Bananas were found only at the annual family reunion picnic after haying was finished. Prepared foods were almost nonexistent. Fresh fruits and vegetables were limited by the season and frozen foods were still being perfected by Clarence Birdseye. The only fish I can remember was Gorton's Dried Codfish and canned salmon. The food supply for our major cities was still largely dependent on the production of the area surrounding them.

Some "blue sky" forecasters have drawn the supermarket of the future as a push-button automat with moving belts carrying the shoppers by glass-enclosed display cascs and robots for delivering the groceries to the customers' jet crafts. Anything is possible in this age of outer space exploration, but we're not likely to see a space age supermarket within the next 5 years. Ifaybe because I'm a conservative Vermonter by birth, I think the next fow years will bring few drastic changes that will completely rebuild the supermarket as we know it today. In other words, no robots, no push-button selection, or other magic. There will be changes, but many of them will not be seen by the custoner.

For example, one of the changes that will modify the consumption pattern is now under way in frozen foods. We now have a food supply without season or limited by geography, aided in part by the miracle of freezing. Although we annually consume 48 pounds of frozen food per capita, only one in three families in the U.S. uses frozen foods regularly. Twenty-five percent have never purchased an item of frozen food according to Sam Martin, editor of Quick Frozen Foods. Food retailers have long recognized the inadequacies of their display equipment, much of which was adapted from early icecream holding cabinets. Equipment manufacturcrs have developed and retailers are now installing double-deck and tri-level vertical cases with air stream curtains instead of doors. The colorful packages now at eye level dramatically present the full range of items from cakes to chinese dinners. The upright cases, in addition to improving the presentation of frozen foods, will do away with the need for being an agile, adventurous acrobat, and possibly losing one's balance when retrieving items from the bottom of deep cases.

Let's turn to an area vital to marketing at a profit-the consumer who will be shopping the food store of the future. Do you know as much about your potential customers and how they respond as you should, to capitalize on the expanding markets of the future? Mr. Willian Capitman of the Center for Research in Marketing had some strong words for marketing firms at a recent Chicago meeting.

"Markcters are still presenting their products and designing their packages as if the population were one homogeneous mass rather than attempting to define the segments of the population who are the real potential customers. We are at least a decade behind the changes that have taken place in American society and purchasing bchavior. Criteria for packaging design are still based on such static and mechanical conceptions as legibility and visual impact, rather than being involved with the people who are perceiving, responding and purchasing.

"The fact that $20 \%$ of the population of our major cities are Negroes, that nearly another $20 \%$ are aged, that the median age of our population is rapidly declining, and that the total population is increasing in size, in influence, in education, in sophistication, in leisure time, all mean that packaging, and marketing, must take totally new sorts of approaches. Each of these segments is bccoming a separate market, as the centrifugal forces at work in our society opcrate. Yet marketing men persist in approaching the population as though it were one big market, made up of white, Protestant, middle class, young, suburban corporation executives and their wives."

I also asked Bill Nigut of William Nigut Associates, Chicago, if he could "shed any light" on the question of what women think about fish and seafood. Bill has developed an outstanding reputation for using consumer panels to discuss marketing problems faced by food nanufacturers, processors, and supermarket operators. From his experience with both panels and 1,500 home interiews, the following facts stood out:

1) 13.5 percent of the housewives do not serve fish or seafood, either fresh or frozen.

2) 16.5 percent scrve it less than once a month.

3) Of those who didn't serve fish or seafood, the most common reason given was that their families didn't like fish.

4) Most women had no opinion either good or bad about the fish or seafood department in the stores in which they shopped. They simply did not recognize that such a department existed.

In the minds of too many consumers, fish is associated with Friday and Lent. Phrased another way, it's something you might eat when red meat is not available. I know some of you are saying that this is too harsh an indictment of the industry, but stop and recall how much of your total yearly sales are made during the six weeks prior to Easter. The poultry industry 20 years ago faced a similar situation, although for different reasons. Turkeys were for many years thought of as a holiday purchase by most families. The development of a frozen bird and a vigorous promotional program for turkey parts and specialty packs, including rolled turkey breast, has changed consumer buying patterns. Prepared turkey dishes are now available along with basic turkey parts throughout the year.

What will it take to change the association and the purchasing patterns of consumers for fish and seafood? The inevitablc answer is more outstanding products and a concerted and skillfully executed advertising and promotional program to broaden the consumption base of the industry.

As I reflected on how I might develop the central theme of my remarks, "selling up to higher profits," I recalled a talk given by my Cornell colleague, Dr. Max Brunk, to an industry that you consider one of your major competitors, which will go unnamed. I thought you might be interested in what he told 


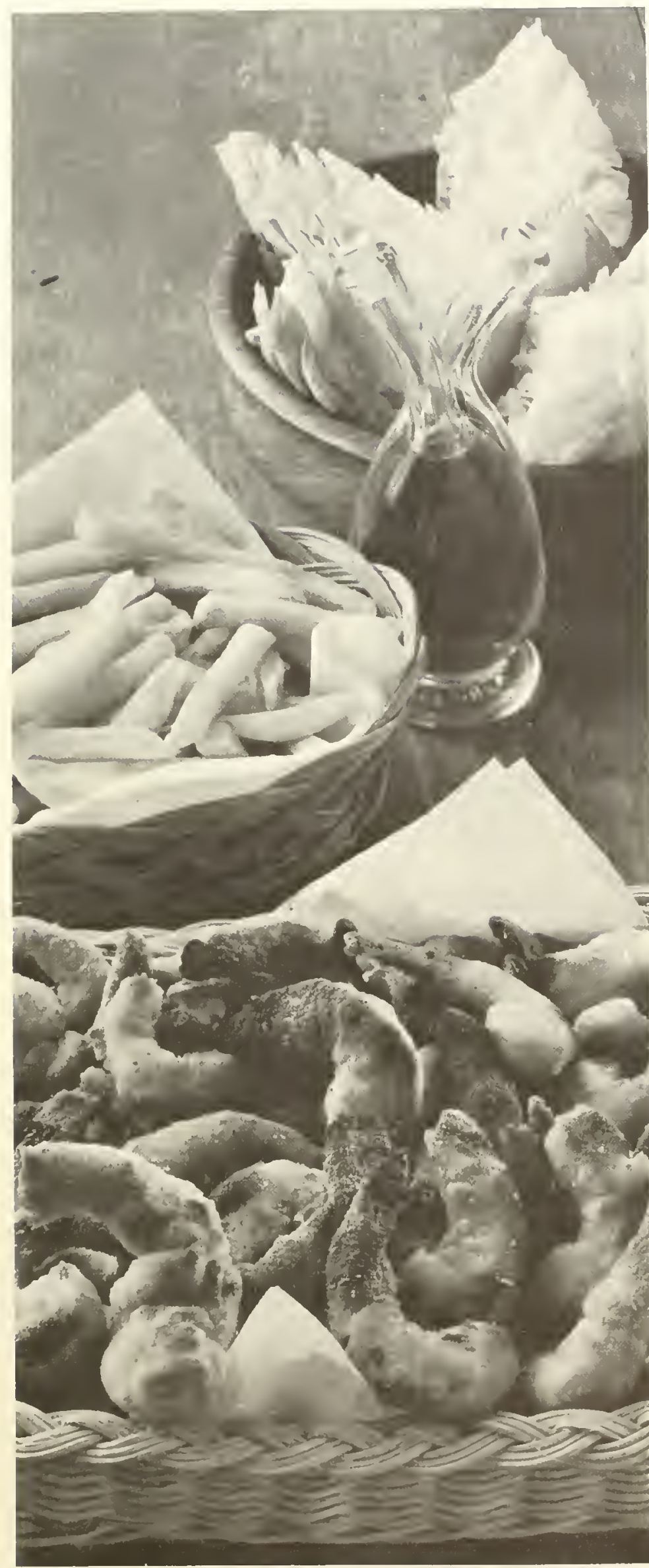

your competitors for the consumer's food dollar needed to be done if they were to prosper. I have substituted fish for your unnamed competitors itcm. I believe you will agree that the following comments by Dr. Brunk apply' equally well to the fish industry.

"Today marketing offers at lcast as much opportunity for profit as docs production but you will never see that opportunity or reap the reward it offers until you recognize marketing for what it is

"First, what are the present sources of profit in fish packing? They can come from but three places. They can come from markup on commodity; they can come from any advantages you can cstablisl in production efficiency and they can come from marketing services you render.

"You are working on the first two and neglecting the latter. The buying or catching of fish is a simple process. The selling of a raw commodity is a simple process as is the packing of fish. Few secrets and special skills are involved. The main requirement is capital investment. That is why the profits you earn on your efforts aproximate the going rates of interest on low risk capital. In other words, the profits you carn are payments for services performed. This will be true so long as you concentrate your efforts on producing and selling a conmodity. This will remain true so long as you regard marketing services merely as an instrument for selling the pieces of fish. Only when you begin to regard fish as the vehicle for selling services will you begin to reap the standing reward of true profit which the market offers. Make no mistake about it, you are in the business of discovering, producing and selling marketing services. At least you should be in the business of discovering, producing and selling marketing services for herein lies much of your opportunity for profit.

"An industry that has long regarded marketing as a cost will find it difficult to accept such a proposition. Any production-oriented business regards marketing as a cost . . . as nothing more than the cost of performing those services necessary to meet competition and move product to the consumer. That is the way you look at pricing. That is the way you look at advertising. That is the way you look at packaging, at merchandising, at salesmanship, at the whole array of marketing services.

"Right here we have the key difference between a production and a market-oriented industry. Marketing to a marketoriented business is nothing more than a continuation of the production process . . a continuation of the process of adding value to the product from which profits can be derived. In a marketing-oriented industry every individual marketing activity is a source of self-gencrating profit.

"We must understand that there is a vast difference between marketing costs and marketing services. Marketing services add value to a product and thereby generate a source of profit. This is not necessarily true of marketing cost. Every marketing service has a profit and loss statement. Its income is the value added to the product and its expenses are the cost of performing the service. This is not true of marketing cost . . it has only expenses. In the fish and seafood business, there are many so-called marketing services that you perform which 
do not add value to the product you sell. But first, let's reeognize that in a true marketing sense these are not really services.. they are costs. They are nothing more than concessions to your customers to maintain an account. Too much of the retail fish business has been built on price concessions with little or no profit to you.

"Any true marketing service adds value to the product. When you can add a new convenience to your product you add value, and only when you add value do you gain opportunity for profit. When you can add a new appeal to your product you add value. When you extend availability you add value. You add value when you offer an improved performance such as kecping quality, a new use, or a new benefit, or a new confidence, or when you create an added desire or improved appearance. In fact it is only through marketing services such as these that you can differentiate in the buyer's mind the product you scll and find new sources of profit. A basic fact is that you can only differentiate marketing services. I'ou cannot differentiate a raw commodity. All that's really marketable in any product is the bundle of perceivable services embodied in it. That is why I say that the raw commodity must be ursed as a vehicle-a rehicle on which and with which you can sell marketing service."

At this point you are probably saying that the professor has philosofied enough and you would like to get down to the serious business of where do we go from here.

Fortunately, I have had the benefit of telephone interviews with several leaders of the fish and seafood industry and food chain executives. My special thanks for their willingness to share their experiences and suggestions for a program for the future.

Tom B. Pearce: Jr.

Sea Pak Corporation

St. Simons Island, Ga.

Edward J. Piszek:

Mrs. Paul's Kitchens

Philadelphia, Pa.

R. P. Fletcher, Jr.

Booth Fisheries Corp.

Chicago, Illinois

Food chain executives interviewed:

Howard R. Rasmussen and Peter McGoldrick

Jewel Tea Co.. Inc.

Melrose Park, Ill.

John M. Mugar

Star Markets

Cambridge, Mass.

The growth of the industry will have to be based on new product development, particularly in the field of specialty items rather than commodity products. The industry is moving in this direction along several fronts, but the efforts need to advance at a more rapid rate.

Members of your industry as well as the retailers interviewed were in agreement on the need for expanded product development as the base for greater per capita consumption. Can we also identify opportunities in advertising and promotion? Members of your industry indicated that the areas of opportunity are of 3 basic types:

1) Selling consumers

2) Selling the food trade

3) Selling food editors

Obviously, a job of this magnitude cannot be done by a single company or even by the entire industry at one time. Priorities need to be established and then adequate funds obtained to build a sustaining program with impact. This is not a $\$ 25,000$ effort; it isn't a $\$ 100,000$ program; it probably will cost in excess of $\$ 500,000$ annually. Can your industry afford a program of this magnitude? My conclusions after studying trends in sales, previous efforts and consumer knowledge and understanding is that you cannot afford not to make an all-out industry effort. An assessment of $1 / 2$ cent per pound on all domestic and imported fish would provide $\$ 24,000,000$ annually. In the hands of an imaginative and experienced advertising man, a profit-making program could be developed that would position the fish and seafood industry in an entirely new light.

Others among your industry were most pessimistic about any industry-wide effort even succeeding. Such comments as the industry is divided in size of operation, type of markets used, product lines carried, and a history of support by a few and free rides by many were mentioned. I personally don't subscribe to using history as a basis of planning for the future. There are always a number of Monday morning quarterbacks available to diagnose the reasons for failure to win. Today, the industry needs a fast backfield supported by a strong line of industry members.

The fish industry needs a symbol that the public will remember. One of the best currently in use is the coffee industry's emissary of good will, Juan Valdes - and his white burro. The fish and seafood industry needs a similar focal point for its advertising and promotional program. I suggest "Eric the Red" for your consideration.

Needed even more than a symbol, according to food retailing executives, is an extensive program to acquaint consumers with the nutrient values of fish and seafood and its preparation. There is no question that fish and seafoods are highly desired products as demonstrated by the amount consumed away from home. Institutional sales are more than double the sales through food stores.

I am convinced that many housewives do not serve fish because they are not confident in their ability to prepare it properly. You need to find ways to help housewives place fish on the American dinner table more frequently in ways that the entire family will enjoy. One executive phrased the problem this way: "Methods must be found to take the fishy taste and odor out of fish."

Some of you will not agree that this is a problem, but to American housewives it is a distinct handicap. Too many people still remember the fish and the fish stores of their youth. The fish and seafood offered in today's seafood departments 
have changed, but individual memories of an earlier era linger on.

Perhaps your greatest opportunity lies in convincing the youth of the country that fish is delicious, titsty mealt. Fish sandwiches at drive-ins are a step in the right direction. Well prepared fish and seafood served in our schools is another contribution. I'm not convinced that your industry can wait until the next generation matures. Action is needed now with today's housewives. The problem needs to be attacked on sereral fronts. It would be presumptuous of me to suggest how to convince the American housewives that fish and seafood preparation can be approached with confidence. Obviously, food editors, schools, tie-ins with manufacturers of selected products, special cooking schools, cook books, and paid advertising all have a place in any meaningful program.

Professor Brunk spoke of marketing services, particularly those that generate profits. I think we are in agreement that fish and seafood are a profitable section of supermarkets, but it can be made more profitable if in-store merchandising were more imaginative. I seafood training program for the manager and those responsible for running the seafood department is a high priority project. Using the techniques of training the trainers, the entire organization from supervisor, merchandiser, to department manager should be included. The need for this type of service grows out of contrast in experience and interest of personnel in a perishable department, such as produce, and those assigned to the seafood department. In the produce department you are likely to find a department manager that either grew up in the produce business or had family affiliations which motivated him to develop and operate an ontstanding produce department. Unfortunately, there are not enough displaced downeastemers with either an understanding of or appreciation for fish to staff the seafood departments of the nation's food stores.

A fundamental back-to-basic type of on-the-job training planned by your association and executed by member firms is needed by retail food store operators. A leaf from the trade service projects of the Campbell Soup Co. would certainly be worth studying.

Retailers need to be offered programs that will make it possible for them to profitably advertise fish and seafood every week. Consumers need to be reminded that frozen fish and seafood make freshness and flavor available throughout the year in forms never dreamed of 10 years ago.

All of us need to recall Henry Ford's statement that "Business is never so healthy as when, like a chicken, it must do a certain amount of scratching for what it gets".

Frohman: This meeting would be incomplete if we didn't give you a brief report of what we have been doing and what we propose doing. We haven't been entirely asleep, as you all know. And now I want to give you just a few examples of the activities of the N.F.I. Promotions Division, with the help of Murray Wheeler, N.F.I.'s Director of Advertising and Publicit:

Murray, what about newspaper publicity?

Ithecler: Every day, every week, every month, newspapers all over the United States are publishing new stories about our products.

Production of breaded fish portions at Blue Water Seafoods plant. A series of cuts with high-speed saws turns blocks into uniform portions desired
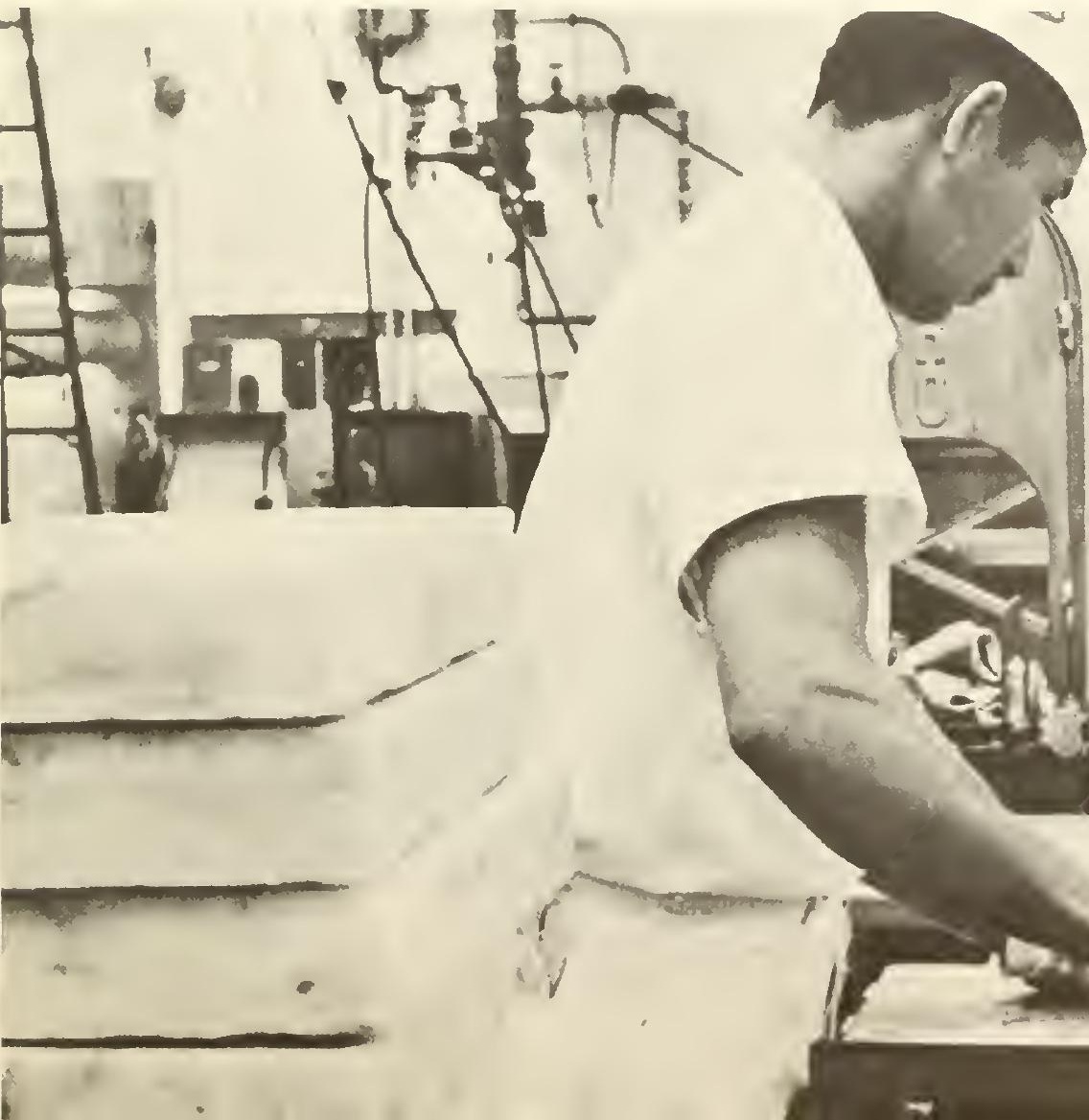
Wheeler: Radio and TV are important, too!

Wheeler: Yes, we put a lot of effort into both radio and TV. 670 radio broadcasters and $132 \mathrm{TV}$ stations used our material during the Parade last fall.

Frohman: National magazines do a most effective job.

Wheeler: With full color photographs, fish and seafood dishes have real glamour. Several samples: GOOD HOUSEKEEPING, March (circ. 5,200,000)-three full pages of color. PARENTS, February (circ. 1,900,000)-most important to our new, great, growing generation-full page color photographs, plus 4 pages of recipes, with an article, "Fish with a Flare." LIFE Magazine, February 19 (circ. 7,200,000 ) - a double spread in color, "Fish Stew." What family can look at this double spread without being impressed by a great image of our products.

Frohman: Let's not forget the mass-feeding market-that's an important part of our business.

Wheeler: Yes, this is a tremendous market for our products and we do a lot with the quantity feeding magazines directed to hotels, restaurants, drive-ins, ete. FAST FOOD, February, fish platter-full page in color; COOKING FOR PROFIT, February, color and black-and-white photographs; VOLUME FEEDING MANAGEMENT, February, 3 pages of color, "fish appetizers".

Frohman: What about the use of our color photographs in the Sunday Newspaper Supplements?

Wheeler: This represents one of the most important phases of our publicity work. We furnish the color transparencies to these leading metropolitan newspapers, which can use color.
Here are three samples used during Lent: PHILADELPHIA INQUIRER-February 28; NEWARK NEWSFebruary 21; ATLANTA JOURNAL-February 28.

During a year's period, about 50 of our photographs are used by the large metropolitan Sunday supplements throughout the country.

Frohman: These are just a few samples of our programs in action-Now, we want to show you what we have planned for the Fish'n Seafood Parade for fall.

Wheeler: "SELL UP TO HIGHER PROFITS" is the theme of our program today. This is the theme of our 1965 Fish'n Seafood Parade. But we must be realistic. If we are to SELL UP TO HIGHER PROFITS we must convince the retailer and the mass feeding operator that he will share these profits with us. That is exactly what we have done in the two ads which will run this summer in the retail and food service magazines. Each of you will receive a brochure showing what our fall promotion can do for you.

Now, what can you do for the fall promotion-to make it work for you. If you want a successful Fish'n Seafood Parade, do what they did in Boston, Atlanta, Nashville, and Seattle. Set up an active promotion committee in your areas.

Frohman: Gentlemen, we are progressing in our promotional work. But it is not enough and unless we take some big steps ahead, it may be too late.

Since $50 \%$ of our products are imported, the domestic industry and importers must share the responsibility of greater promotion efforts. Now is the time.

Frozen scallops about to be battered and breaded at Gorton.

Fish sticks passing from batter to breading.

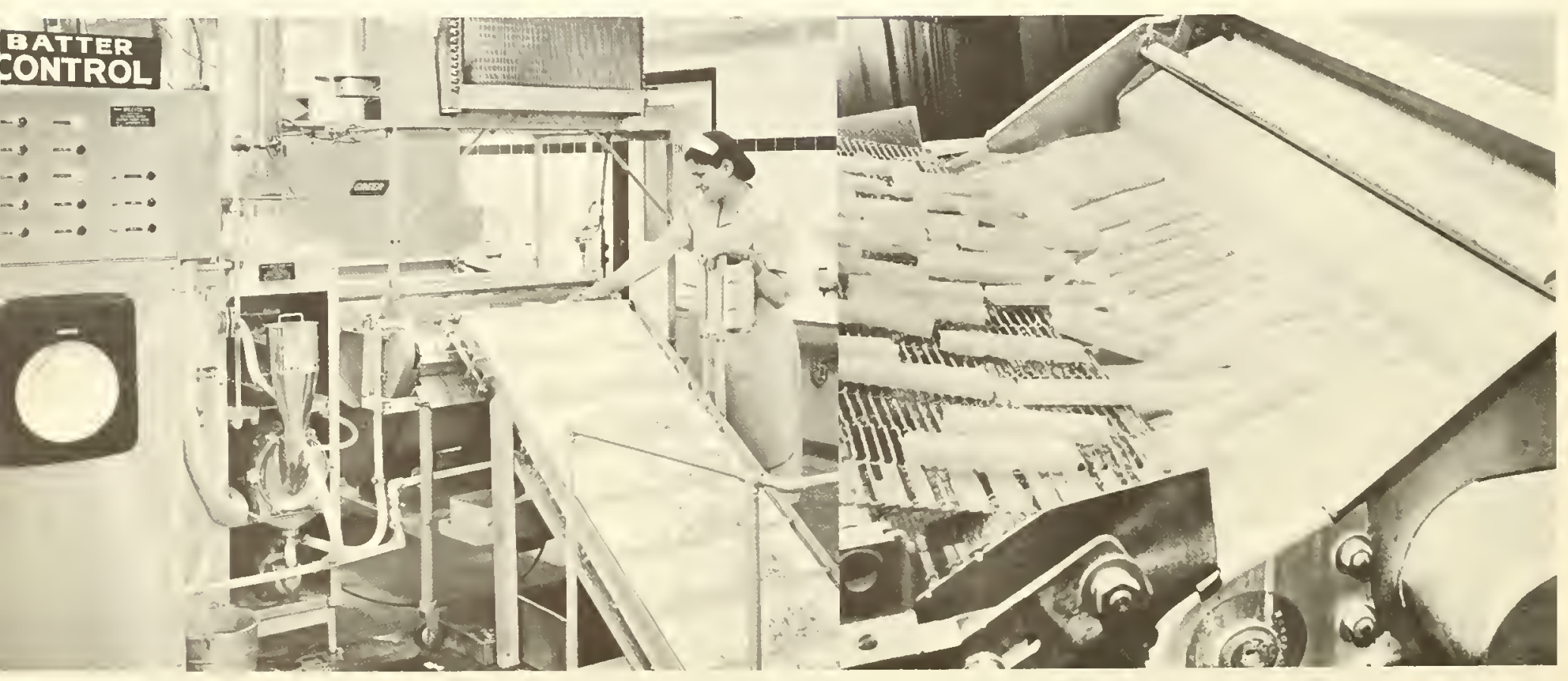




\title{
All the World's a Market
}

\author{
by Hon. Mitchell Sharp \\ Minister of Trade and Commerce for Canada \\ Ottawa, Canada
}

It is alwars a pleasure to visit Washington and especially at this time of year. You have shown great wisdom in the venue and timing for your conference.

I particularly welcome this opportunity to meet our North American neighbors and to review with them our important and joint interests in the development of the fisheries resources of this continent. While I am not a fisherman, nor like my colleague, Mrr. Robichaud, an expert on fisheries, as the Canadian minister responsible for trade I have a major interest in the markets for fish both here and throughout the world.

This is the first time that I have participated in a tripartite meeting of this kind. The very fact that the fishing interests of Mexico, the United States and Canada have chosen to meet here in Washington is, in my view, a reflection of the growing consciousness of our ever-increasing interdependence. I have no doubt that you will have many difficult and complex problems to review over these two days. Neither have I any doubt that through full and frank discussions you will see a good deal more clearly where the best interests of the North American fishing industries lie and the best way to pursue and develop those interests.

I have been billed to speak on the subject, "All the World's a Narket." Certainly, all the world is a market for fish. I understand that during 1964 over 15 million tons of fish moved in or out of 140 countries. Your industry is obviously achieving in its own substantial way the goals that enlightened men nations are working for throughout the world--the expansion of trade to improve the economic welfare of mankind.

It has been estimated that the world's population is increasing by 100,000 persons every day. We have been warned that by 1975 world requirements for animal protein will have increased by 50 percent. If that demand were to be satisfied entirely by fish, it would amount to an increase of 55 billion pounds per year in the present world annual fishing catch. This magnitude has, I am sure, special significance to my colleague.

Will the fishing industry rise to the challenge? New methods of maintaining and improving yields will be necessary. The pace of research must be accelerated. It is sobering to remind ourselves that we are eating much the same kinds and forms of fish that our ancestors ate 300 years ago and that numerous species are still not commercially exploited. Obviously, the sea still has much to offer.

Nor have we yet created the kind of international trading conditions that will provide maxinum encouragement to the consumption and efficient production of fish. We are, I believe, moving in the right direction but there is still a long way to go.

I turn then to some trade matters of particular concern to Canada. Canadians of course have a tremendous stake in exports. One of every 5 dollars earned by Canadians is derived fron exporting. With such a stake in export trade we have pursued consistently policies designed to obtain better access abroad for our products. Trade with the United States - the world's largest and richest market-is of key importance to us. I am happy to say that this trade is thriving. Our sales to the United States in 1964 exceeded \$4 billion. They have been rising almost as fast as U.S. sales to Canada. Last year, $53 \%$ of Canada's exports went to the United States; $71 \%$ of our imports came from the United States. I put these few facts on the record so that my American audience will understand why we Canadians react so forcibly, and I have no doubt that Mexicans do as well, to measures to restrict trade. Our economic well being is too vitally dependent on international trade for us to do anything else when our trade and economic interests are threatened.

There are two features of Canada's trade and economic situation to which I would like to draw particular attention.

The first relates to Canada's external payments position. In the past decade Canada has incurred unusually large deficits in our international exchange of goods and services. Good progress has been made in recent years in lessening this imbalance with the world at large. Canada's deficit on current international transactions has been reduced from a high of $\$ 1.5$ billion in 1959 to just under $\$ 1 / 2$ billion in 1964 .

However, Canada's current deficit with the United States has exceeded $\$ 1$ billion each year for the past decade and last year rose to a new high of nearly $\$ 12 / 3$ billion. In terms of our respective national products, for the United States this would be comparable to a deficit of $\$ 24$ billion. This deficit of $\$ 12 / 3$ billion with the United States was covered by a surplus with the overseas area amounting to $\$ 1.2$ billion in 1964 , and 
by borrowing. Notwithstanding Canada's vigorous export promotional efforts in all parts of the world, our surplus with overseas countries is not likely to hold to the 1964 level when unusual influences were at work. Nor would it be prudent on our part to rely indefinitely on the availability of foreign capital to meet the bulk of a deficit of this size with the United States. Canada must therefore look to progressive expansion in our presently disproportionately small share of the North American market for goods and services as a whole.

Meanwhile the Canadian economy has been moving strongly forward. For the past four years national output in real terms has risen at an average annual rate of about 6 percent. At the same time, our newly formed Economic Council has estimated that we must maintain such a pace of advance, i.e., $51 / 2$ percent on average each year for the next five years, if our rapidly expanding adult population is to be employed and if our overall productive potential is to be adequately used. Achicvement of this target will depend in a very basic way upon the further expansion of international trade. It will depend also on the development of our manufacturing and processing industries in the direction of increased efficiencies and competitiveness. Traditionally, Canada's exports have consisted largely of products of the earth, the forest, and the sea. Basic resource industries will continue to be of major importance in our export trade. At the same time, we can no longer rely on these industries to provide so preponderant a proportion of our forcign exchange requirements. We must strive further to expand our share of the world market for highly nanufactured products if we are to hold our own.

This means a basic transformation in our secondary industry. That exports of end products have doubled in the last three years is an indication that this transformation is under way. It is doubly significant that in this sector the greatest activity has been the increase in Canadian exports to the United States. This country presently absorbs more than half of Canada's exports of end products. It is this market which must hold our greatest promise for the future.

Canada's fisheries industry has alway's had and will continue to have a major role in Canadian economy and in Canada's international trade. The total value of fisheries products in Canada has increased over the past 10 years by $50 \%$. Exports amounted to $\$ 203$ million in 1964 and have kept pace with the overall output. While this has been encouraging we must continue to look to world markets for the further expansion our industry needs. I am pleased to say that the prospects for the future look good. Our fisheries people, who have been known to be pessimistic from time to time, expect a firm market. Iccording to their surveys around the globe there are no overhanging stocks in most producing countries or in world markets. Accordingly, it should not prove difficult to sell the available quantities of good quality fisheries products, in their various forms, at competitive prices. I do not propose to embark on a more detailed world market analysis. There are many here more competent than I to provide chapter and verse. For my purpose it suffices to emphasize the buoyant market situation in prospect. It is always a pleasure to submit a rosy report,
CANADA'S FISHERIES

Total catch and value 1955-64

catch in

millions of pounds

landed value

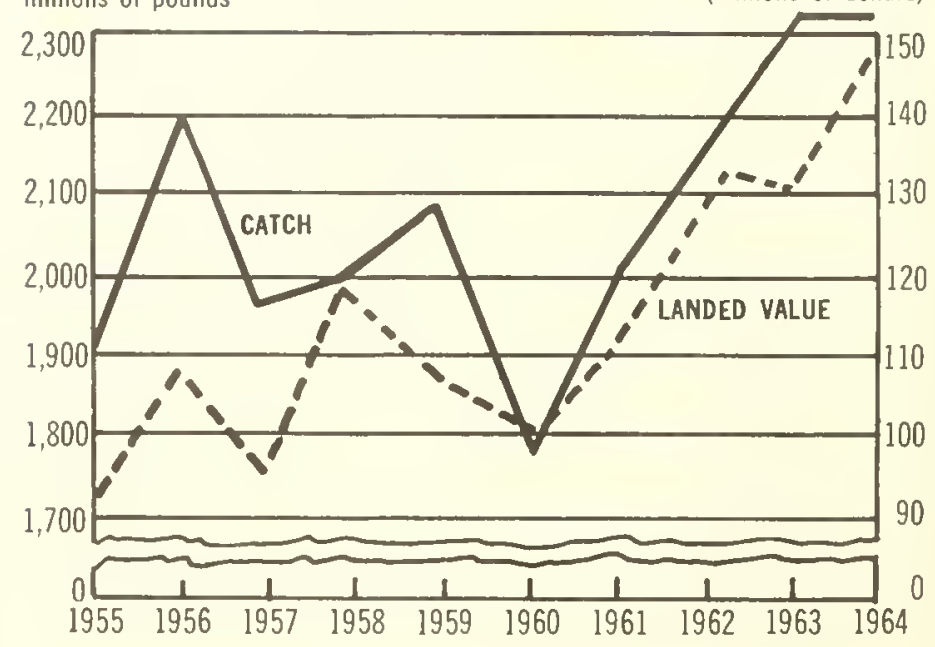

but it is also dangerous, and I hope that you will work diligently to ensure that my predictions come true.

As I have said, we in Canada will be looking for markets wherever we can find them. First and foremost for us and for our Mexican friends is the North American market. Canada has annual landings of over two billion pounds. About two thirds of this is exported in product form. The United States is our biggest customer, accounting for sixty-five percent by value of our export sales of fish. Canada is also an importer of fish. Besides bcing the best market for American fisheries products, we also import important quantities from Mexico.

While tariffs between Canada and the United States in fish products are not high, there is one notable exception. The U.S. tariff of some thirty percent on cooked fish sticks has created a marked distortion in North American production and marketing. I can't believe that a tariff at this level makes much sense. I hope the group meeting here today and tomorrow shares this view, and that a more constructive solution can be found.

Several years ago Mexico placed restrictions on our sales of sardines to their market. It seems to me that there should be some way to reopen this trade.

In general, with the market situation and prospects so firm, there is a good deal to be said for considering now a move towards freer trade in fish and fish products.

Not only is the market situation propitious but the negotiations already under way in Genera provide the instrument for Canada and the United States to move forward together in the direction of lowering trade barriers not only between us but in markets for fish throughout the world. I have no doubt that the international arrangements are flexible enough for Mexico to join in this should they so wish.

A word about the Kennedy Round to which I have just referred. As the bargaining gets tough and frustration after frustration is encountered, a sense of discouragement may 
become prevalent, the gloss may tend to wear off. This is to be expected in a trade conference of such magnitude, of such far rcaching significance. However, such a programme, so important to future trade and economic cooperation, is surely worth the effort that is necessary to bring negotiations to a successful conclusion.

We have in the postwar period made great strides in international trade and econonic cooperation. At the close of the war, the debilitating effect of the beggar-your-neighbor policies of the 1930's were still vividly impressed on the minds of governments. There was a general determination to work out the kind of trade rules which would prevent a recurrence of the 1930's. The leadership of the U.S. has been a most important factor in the success of thesc efforts.

These trade rules are now subject to considerable strain. I have no doubt that the time is come to adapt our trading rulcs in order to serve better the needs of the trading world of the 1960 's. What I would caution against, however, is throwing away the hard-won trading framework and rules without having something better to put in their place. At times such as these, when the trading world is tending to break up into trading blocs - the EEC, the EFTA, the LAFTA - or between the developed countries and the less developed countries, we in Canada sometimes get the feeling of being neither fish nor fowl. Voices are raised in favour of joining one or other of these trading blocs, or developing a trading bloc of our own. There are also voices calling for withdrawal-a move toward economic isolationism.

1 belicre that the multilateral trading world that we have fashioned in the postwar period has well served the trade and economic interests of the Western world. It has already contributed to an extraordinary increase in volume of world trade and a significant reduction in barriers to trade. The Kennedy Round holds out the opportunity of maintaining the momentum. We cannot afford to miss the opportunity.

There is also an insistent and urgent need to help the less developed countries raise the living standards of their people. I regard the trade problems of the less developed countries and the need for them to have an opportunity to improve the lot of their people the greatest challenge of the 1960's. This issue is being squarely faced by the world trading community.
The developed countries are, I think, very much aware of the importance of opening up markets for the products of the developing countrics. The Kennedy Round provides an important opportunity to reduce trade barriers facing the products of particular importance to the developing countries. Trade in fish is not unimportant in this context.

While we have not had the pleasure of working with our Mexican friends in the GATT, we have developed close relations with, and a great admiration for, our Mcxican friends in the many international commodity discussions and conferences where we have worked together. It scems to me that cooperation in the commodity field holds great promise and that we all have a stake in developing its full potential. In this we must be realistic. Enduring bargains can only be struck when a fair balance is reached. There is clearly a need for international commodity cooperation designed to cnsure remunerative and stable prices to efficient producers. There is an equal need to ensure supplies at reasonable prices to consumers not only to protect the consuming interests but also to ensure a continuing strong and healthy market.

I have taken this occasion to stress particularly the importance of cooperation in the fishing industry and the benefits to be received from world trade. I would also like to sell you on a holiday in Canada. Not the least of our attractions are the fine game fish of our Maritime coasts and inland witers. I have no doubt that even the people in the fishing industry are not adverse to taking a busman"s holiday.

In conclusion, I commend you for the initiative you have shown in bringing this group together and I wish you well in your deliberations. I an confident that the fisheries industries of North America represented here can bring to bear an understanding and consideration that is vital to international trade cooperation and maximum trading opportunities. I know that the Canadian industry for its part has been looking forward to the opportunity to exchange views with their counterparts in the United States and Mexico. They are anxious to explore the possibilities for improving the interests of the North American fishing industry through closer cooperation. I am convinced that through conferences such as this, the trade and commerce between countries can be greatly enhanced and strengthened.

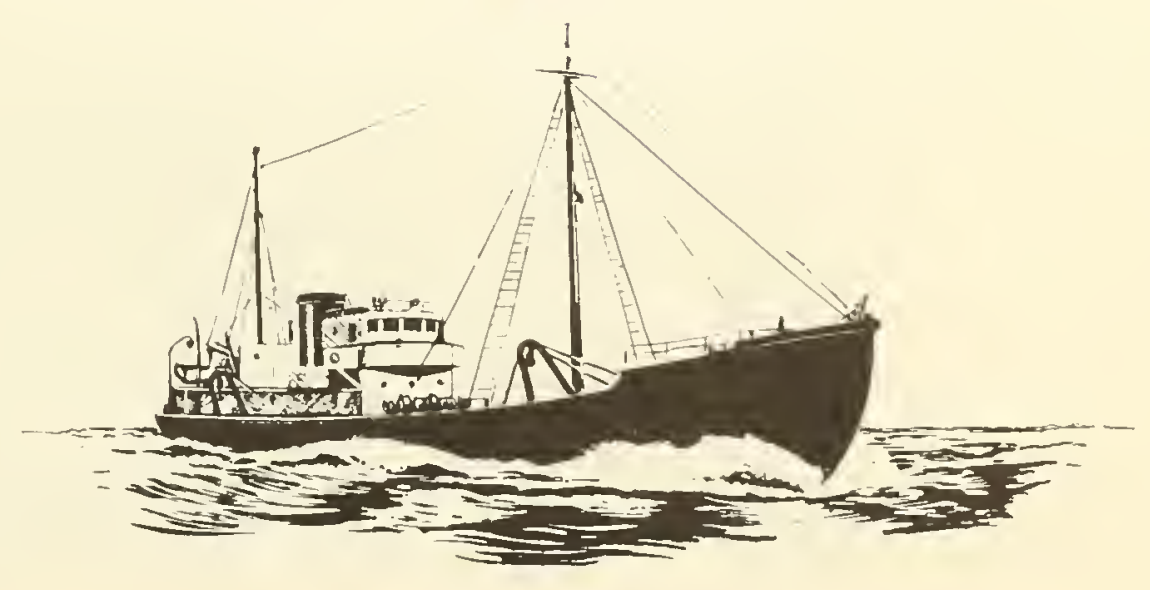




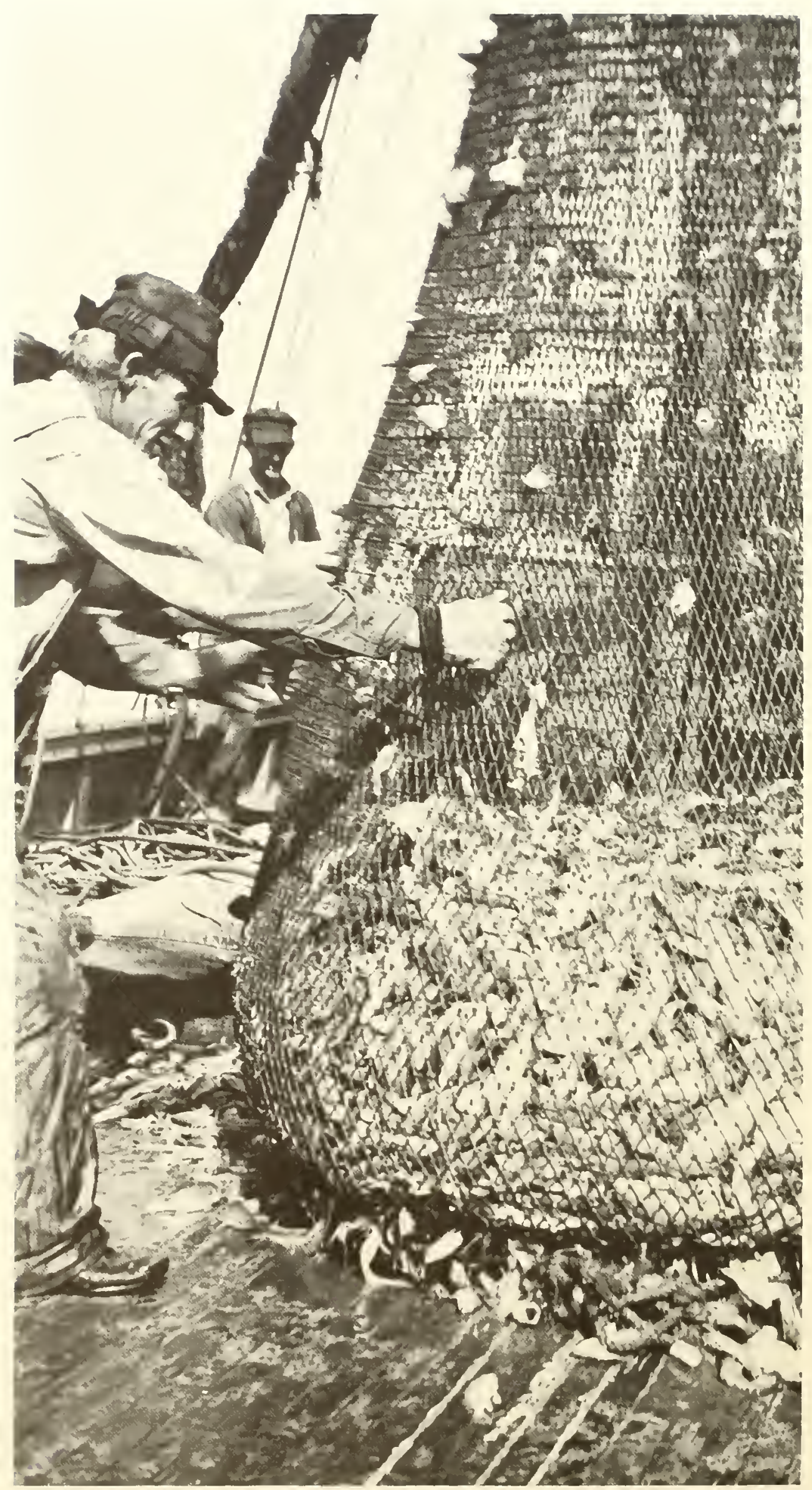




\title{
World Demand Complicates Conservation
}

\author{
By Hon. H. F. Robichaud \\ Minister of Fisheries for Canada \\ Ottawa, Canada
}

It is indecd a great pleasure to be here and to have the opportunity of speaking to you on a subject of great concern both to the fishing industries of our three countries and to their governments. It has never before been so important to mobilize our very best efforts, both nationally and internationally, to see that the resources on which your great industries depend are thoroughly yet wisely used so that they will remain productive for generations to come.

I think it is a very auspicious occasion when associations of your stature, representing as you do the fishing industries of Mexico, the United States and Canada, meet to discuss matters of common interest. I am sure that now on the closing day of your joint meeting you have already had a very valuable exchange of views, which will help the future development of all phases of the fisheries of our three countries, to the benefit of fishermen, processors and consumers alike. No subject, however, can be of greater or more pressing concern, than the conservation-and by this I mean wise use-of the fisheries resources themselves.

My subject has to do with fisheries conservation problems in the light of increasing world pressure on the fish stockshence the announccment of the title, "World Demand Complicates Conservation." Perhaps it would have been more appropriate to stress the essentiality rather than the complexity of greater conservation efforts.

Our countries, and indeed the whole world, face an explosive situation in which the expanding fishing effort may seriously damage the resource if not tempered with sound management. In the last two decades we have seen a rapid increase in the world's catch of fish brought about by similarly rapid increase in the size and efficiency of the fishing fleets. Supported by an ever-increasing need for the good protein food which comes from the sea, this trend will continue and the necd for our very best efforts to manage the fisheries wisely will become ever more acute. The challenge must be met on both national and international levels if the livelihoods of future generations in the fishing industry are to be preserved and the nutritional needs of the world's teeming millions are to be satisfied.

One aspect of the great fisheries' expansion of our times has been the development of far-ranging fleets capable of intensive exploitation of fish stocks at great distances from their homc ports. The mobility and fishing power of such operations mean that newly discovered fish stocks may be reduced in abundance very rapidly, sometimes before there has been an opportunity to make a scientific assessment of their potential. This can result in economic loss by all concerned-by the operators of the mobile fleets who lack the basis for sound planning, and by the countries which may watch the resources at their doorsteps dwindle before their eyes, sometimes before they can reach a level of development which would enable them to take part in the exploitation.

It may be doubted whether these very expensive operations far from their home countries are economically sound, and can in the long run compete with fisheries based on near-by ports. The future may well lie with well-managed operations based closer to the fishing grounds. Be that as it may, the existing mobile fleets pose a serious challenge to the world's, as yet inadequate, organization for international fisheries research and regulation.

Fisheries, in contrast with other industries based on living resources, such as agriculture and forestry, suffer two great handicaps. On the one hand, the fish are hidden from our sight and more difficult to study than the resources on land; hence special efforts are needed to provide the scientific basis for getting the best yield from the fish stocks. On the other hand, the fish stocks must usually be classed as common property resources and, unlike the farmer or the lumberman, the fisherman cannot usually have private control of that part of the resource which he uses. Under these circumstances governments must carry out the research and the regulation of fishing, as well as positive fish culture to increase the resource where that is possible. A similar situation exists internationally. While some fisheries resources may properly be classed as national property, most of the great existing and potential ocean fisheries are international in nature and, to bring about wise use of these resources, it is essential that international agencies be developed and strongly supported.

Thus, the first step towards wise use of fisheries resources, nationally or internationally, must be intensive research on the fish stocks and on the effects of both fishing and natural factors on their abundance and yield. It is possible, on the basis of thorough research, to estimate the sustainable yield and to devise 
means of maximizing the yicld through regulation of the kind or intensity of fishing. The second step is to formulate fisheries regulations which take into acount such scientific findings as well as cconomic factors in fisheries development and maintenance. The final step is to enforce such regulations. In a few cases, such as salmon, it is also feasible to increase abundance and yield by fish culture techniques and such efforts should be pressed. Exen in these cases, however, the sound cxploitation of the resulting increased resource depends on the same three steps of research, formulation of regulations and enforcement.

These three steps have all been taken in a few cases but even in the best cases there is room for improvement and, especially in the international ficld, we are still at a very early stage of development of management. We must increase our efforts.

I hope I may be permitted to dwell with some pride, but I assure you with no complacency, on Canada's activity in this field. My Ministry has, in the Fisheries Research Board of Canada, an agency with a record of high quality research for over half a century; its work continues to exhibit vitality and progress. My Ministry also has a large and effective organization for development and enforcement of regulations in cooperation with the industry through organizations such as the Canadian partner in this Conference-the Fisheries Council of Canada. I would like in passing to say that without a body such as the Fisheries Council to coordinate the sometimes divergent views of the industry in various parts of our country, our task of mecting their needs would be much more difficult.

When Canada, through Confederation, came into being almost a century ago, there was little realization of the need for fisheries management. Lucrative fisheries for such valued species as salmon and lobster were at first over-exploited. Gradually, however, there has come general realization that fish stocks are not unlimited and must be exploited carefully if the fisheries are to last. This realization came first with regard to species which were in high demand and quickly reduced-salmon, lobsters, oysters, halibut-but the need for scientific study of all important species is now generally accepted and the actual or imminent need for regulation becomes recognized in one after another case as they become intensively exploited. Perhaps we present in miniature the picture in the world as a whole.

At the national level intensive research and regulation have arrested the decline and achieved some restoration of our valuable lobster fisheries on a sound long-term basis. The same is true of certain of our salmon fisheries. In all these cases high and increasing prices have attracted a level of fishing effort which causes serious problems both for maintenance and improvement of the resource and for profitable operations by the industry. Intensive research and regulation are making progress with the conservation problems, although much remains to be learned; we have barcly made a start with the economic problems. Excessive fishing effort not only causes great difficulties in management to maintain the resource but also tends to reduce the profits from fishing, the net return to the fishermen, to a low level. These fisheries thus exemplify: the basic difficulties in the exploitation of common property resources--difficulties which become apparent in international as well as national fisheries as they approach critical levels of intensity.

The United States and Canada are partners in three bilateral conventions for fisheries management. Under the first of these, the International Pacific Halibut Commission set an example to the world by studving orerexploited halibut stocks off our Pacific coasts, imposing strict joint regulation of the halibut fisheries of our two countries, and thus restoring these fisheries to levels of productivity well above that to which the unregulated early fishing had reduced them. Would that such success could attend international conservation efforts on ocean fisheries generally! Under a second convention, the International Pacific Salmon Commission has achieved for our two countries a similar measure of success in restoring the sockeye stocks of the Fraser River, which are subject to fishing in national waters on both sides of the border. In this case the ill cffects of overfishing and of the famous Hell's Gate landslide were overcome by effective fish passes and by strict regulation, both based on scientific research. The Commission is extending its activities to other obstructions and management problems, including positive fish culture measures, and much is expected from its efforts. The third bilateral convention coordinates our research efforts on the Great Lakes and has fostered an enterprising experiment in the control of the sea lamprey which caused much destruction of lake trout. Our two countries are proud of this record of cooperation in fisheries conservation and look forward to greater things to come.

Turning to a somewhat broader international field, the United States and Canada together with eleven European nations are members of the International Commission for the Northwest Atlantic Fisheries (ICNAF), which has coordinated research on the groundfish stocks of that area and initiated regulation through the institution of minimum mesh sizes for trawl nets. As the fishery becomes more intensive, we appear to be on the rerge of the need for more intensive, restrictive measures, and we look to this Comnission for leadership in solving most complex and difficult conservation problems. Similarly the Inter-American Tropical Tuna Commission has conducted research on which to base regulation of the tuna fishery in the eastern tropical Pacific and has advanced to the stage of formulating proposed conservation measures. Here again we wish this Commission well and, indeed, Canada may be interested in membership if our participation in the fishery develops.

We are all aware of other regional international bodies which have promoted research on fisheries resources and are tackling the problem of formulating regulations which would be effective in maintaining the resource and, at the same time, acceptable to member nations often having diverse interests. I mention ICNAF, IATTC and other regional bodies to draw attention to attempts which are being made to effect international fisheries conservation. In spite of the great difficulties which these bodies must face, their efforts must receive our support and must succeed if our fisheries are to remain productive. Cooperative research presents technical difficulties but meets little opposition; joint regulation and especially 


\title{
Mexico's Fishing Industry
}

\author{
by Lic Jorge Echaniz R. \\ Director General of Fisheries and Related Industries of the \\ Department of Lndustry and Commerce of the Government of Mexico
}

Before describing Mexico's efforts to foster the development of our fishing industry, permit me to convey to the National Fisheries Institute of the United States, the Canadian Fisherics Council, and the National Chamber of the Fisheries Industry of Mexico the thanks of Mr. Octaviano Campos Salas, Secretary of Industry and Commerce of the Mexican Government, and of Gencral Abelardo L. Rodrigucz, Chairman of the National Fisheries Consultative Committee, for the kind invitation extended to them to attend this First North American Fisheries Conference.

For reasons known to many of you, these gentlemen were unable to attend this important meeting. In their name I should like to speak in broad terms of Mexico's general economic situation and our activities with respect to our fishing industry.

In discussing contemporary Mexico-which lives and builds under the aura of the creative peace that presides over our progress, which affords work in our ficlds and citics, and which regulates our civic conscience-we must bear in mind that this peace is the product of a long and bitter struggle, nourished by the efforts of our best sons and the vitality of our national heroes.

That struggle was to win our political independence, our economic self-sufficiency and our own distinctive social well being. To affirm our sovercignty and the expression of the will of our people, we daily live and practice our Independence. our Reformist Movement and our unique Mexican Revolution.

The triumphant Revolution of 1910 dramatically transformed us from a land submerged in backwardness to one of vital progress. It wrote finis to a dictatorship and swept away its military and financial supports. It paved the way to agrarian reform and to free universal education at all levels. It stimulated formation of our domestic markets and diversified production and employment in a manner that favored the growth of our population and citics.

The Mexican Revolution, mentor of our economic development, made possible the rational exploitation of our natural resources, ensured a higher standard of living for the bulk of our population, forged and strengthened our independence and greatly enlarged the scope of our international cooperation.

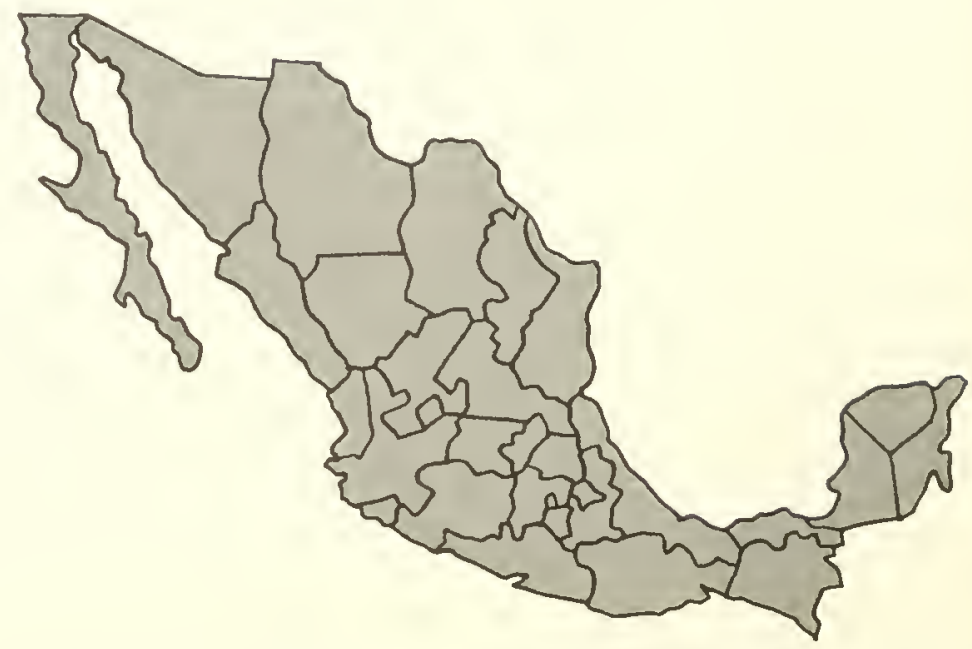

What are the specific products that the Mexican Revolution gave us through the exercise of our constitutional rights?

-Our manufacturing production has increased twenty times since 1910;

-Fifty million hectares of land have bcen distributed to small farmers, and land distribution continues, paralleled by substantive measures to expand our domestic market;

- Gross national product in terms of 1910 prices rose from 13.5 billion pesos in 1910 to 72.2 billion in 1960 ;

-We now have more than 50,000 kilometers of paved highways and 24,000 kilometers of railroad;

-Our daily petroleum production of 384,000 barrels has enabled us to strengthen and integrate our industry. Our present production of transportation equipment and machinery is extraordinary. Our steel industry and the manufacture of rubber goods, metal products, chemicals, fertilizers, synthetic fibers and cement reveal an accelerated rhythm of growth.

In short, we enjoy an industrial diversification that derives from the expansion of our domestic market made possible by the Revolution of 1910 and the calculated participation of the State in our economic life.

We have made many significant advances over the past decade. Here are some of them:

-Our gross domestic product in terms of constant purchasing power has increased 73 percent;

-Our population grew by ten million, from 31 to 41 million, at an annual growth rate of 3 percent;

-Rcal industrial wages increased at a mean average rate of 4.2 percent; 
-Our electric power production increased by 125 percent; petroleum and manufacturing production by 101 percent; fishing by 87 percent; business activity by 72 percent; stock raising by 47 percent and transportation by 43 percent. Agricultural production expanded by 30 percent, a rate lower than that of population growth.

-In 1963 alone, manufacturing increased by 13.5 percent and agriculture and animal husbandry by 6.5 percent. Two industries basic to Mexico's modern development--electric power and petroleum-grew 15 percent and 9 percent, respectively.

The national goal of expanding our diversified economic development to the maximum has led the new Government of Mexico to establish targets of vast proportions. These include:

-A growth in real income of at least 6 percent per year during the 1965-1970 period;

- A minimum of 400,000 additional jobs per year;

- Maintenance of domestic price levels and avoidance of inflationary factors;

-Combining a more equitable distribution of the national wealth generated year by year by our growing development;

A healthy equilibrium anong all sectors of the national economy and between the use and conservation of our national resources;

- Rapid and efficient solutions to the problems of our rural sector;

- Stimulation of domestic capitalization, without the reduction or stagnation of the economic and social contribution of low-income groups.

To attain these goals, coordination among the various public agencies will be emphasized; the tax policy will be affirmed and the supply of money in circulation will conform to the production of goods and services; the national economy will be strengthened; recourse will be had to supplementary foreign credits where required, always within the framework of our ability to repay; productive activities in general will be diversified and new markets will be sought.

Fishing activity will play a primary role in attaining these goals. The fishing industry, as has been noted, increased in value during the 1955-1964 decade by 87 per cent, and expanded catches of seafoods of various kinds, particularly tuna, shrimp and sardines, from 119,000 tons in 1955 to more than 198,000 tons in 1964.

How has Mexico arrived at these goals and how will it exceed them?

The benefits obtained from fishing are the direct result of the intensive efforts of cooperatives, individual fishermen, industrialists and government authorities. These benefits are the solid foundation of future activity, and will tend to support President Gustavo Diaz Ordaz' intention "to make the riches of the sea one of Mexico's basic riches." They will also, in consequence, prevent situations such as that recently described by Mr. Antonio Ortiz Mena, Secretary of Treasury and Public Credit of Mexico, in the following words:

"The fishing industry has expericnced undesirable ups and downs. At one point exports soared in volume and value, but fish for the domestic market was at a minimum. Later, we substantially increased domestic consumption of seafoods while, on the other hand, the catch and volume of certain species sold abroad diminished."

In other words, we are secking to strike a sound balance between fishing for export and fishing to supply our growing domestic market. To do so, the Federal Government, aware of the stimulus required by the fishing industry, "will give it preferential attention."

On attaining this balance, the country and the fishing industry affected by export prices will be less exposed to harmful price fluctuations and will be able to make firm progress in modernizing and replacing boats and nets to improve domestic supply, now at a stage characteristic of an ccononic activity in a developing country:

In view of these factors and in accordance with the Gorernment's desire to encourage the fishing industry, the National Fisheries Consultative Committee was established on December 8, 1961. This agency is an interdepartmental advisory body, whose basic objectives are contained in a twelve-point program, as follows:

1) Establishment of a Fisheries Research Institute; 2) establishment of fishing schools on each coast; 3) a fisheries supervision service; 4) control of contamination and pollution of estuarics, bays and lakes; 5) reforms in fisheries legislation; 6) studies and recommendations to improve the fisheries tax system; 7) recommendations to increase and diversify production; 8 ) recommendations conducive of better distribution of fishing products; 9) continuous publicity and information to popularize the consumption of fish ; 10) recommendations on works necessary to benefit the fishing industry; 11) recommendations on improved credit systems, and 12) coordination between the Committee and the various public and private sectors participating in the fishing industry.

Obviously, the main support of the fishing industry is the availability of natural resources. Mexico, in consequence, has been conducting sound research and quantitative studies in this respect, thanks to the efforts of the National Fisheries Biology Research Institute, of the General Fisheries Administration, sponsored by the National Fisheries Consultative Committee.

This work already has yielded magnificent results, which include Preminary Fishing Charts for both coasts which afford an overall picture of our fishing resources. In a like manner, excellent studies have been made of the biological cycles and habits of various species. The revision and expansion of cceanographic and climatological data is being carried forward without interruption by specialists at the marine biolcry and pisciculture stations of the National Fisheries Biology Research Institute.

Training our fishermen is being carried out in the Fisheries Schools established on both our coasts for that purpose. Their number is being increased to better meet our needs in this respect. The purpose of this training is to train crews for boats operating on the continental shelf and beyond, and thereby enable them to diversify their catches and improve the stability of the industry. 
Fishing activities in Mexico are conducted by cooperatives and concessionaires.

We have fishing legislation which favors fishing cooperatives. There are at present 177 such cooperatives, with 22,119 members, which own 275 boats outright and rent 1.045 boats to the private sector. A basic task of the present Administration in Mexico is to better acquaint the cooperatives with their rights and obligations, so as to obtain better management of the cooperatives and thus reduce their economic instability.

There are relatively few large fishing enterprises, but their influence on the industry is decisive as indispensable links in the production and the purchase and sale of fishing products and because they possess large numbers of boats and gear. They employ 4,432 fishermen and 3,000 workers, and to them goes the credit for having acquired the necessary equipment which permitted Mexico to engage in deep-sea fishing.

At present, they and the Federal Government share joint responsibility for exploiting our maritime wealth and developing a vigorous industry that can take advantage of that wealth. The situation of our small fishermen is quite critical. Their equipment is rudimentary, and for this reason they constitute the bulk of coastal fishermen. A constant concern of our fisheries policy will be to improve their efficiency and production and thereby raise their living standards.

Mexican private enterprise and the Government have made considerable progress in industrializing fish processing. We now have 154 industrial fishing plants, which include 58 canning plants, 61 freezing plants, 16 refrigerating plants, seven fish reduction plants, and seven of miscellaneous types.
Studies are being made as a preliminary to establishing additional plants capable of low-cost industrialization of species which abound in certain areas. These plants will encourage the establishment of nearby collateral industries.

There are also 14,150 nets of up to ten meters in length, 3,015 ranging in length from ten to 100 meters, and 1,535 of a length greater than 100 meters $-18,700$ in all.

In addition, we have 11,541 fishing boats. The majority of these are under three tons, which explains the predominantly coastal nature of our fishing activity. Parallel with our efforts to develop deep-sea fishing, our government officials are encouraging the participation of all sectors of the fishing industry in introducing and intensifying the cultivation of species traditionally found in or near fresh-water lakes and rivers, estuaries, and protected bays, etc.

The sector of the population engaged in fishing is less than 0.5 percent of the total economically active population, and less than 1 percent of the population engaged in primary economic activities.

The development of the fishing industry requires the participation of the Federal Government in providing the infrastructure to attract private enterprise and cooperatives to those areas where, despite the existence of abundant natural resources, fishing activity is weak because of the low purchasing power of Mexican farm families, or where industrialization of fishing production is at a minimum or non-existent, because of a lack of electric power, fuel, water and rail and highway links.

Where fishing is concerned, the initiative of the Federal Government and coordination of its efforts with those of private enterprise and cooperatives is essential to a rapid and gen-

\section{MEXICO-FISH PRODUCTION}

Production in Thousands of Pounds, Selected Years

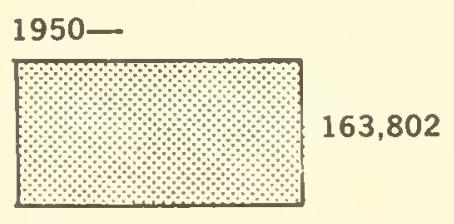

1955-

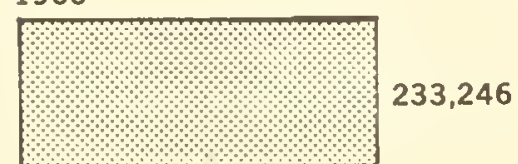

1960

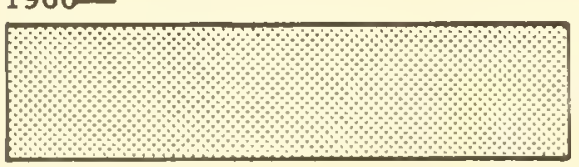

436,290

$1964-$

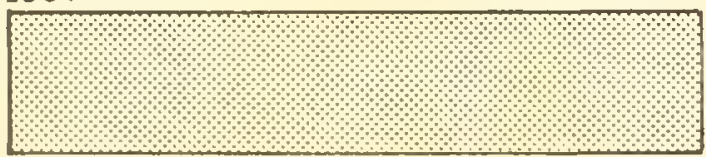

569,668

$\$ 59,976,000$ value
Most Important in Volume and Value-1964

I. SHRIMP-151,896,000 pounds of headson shrimp, 26.6 percent of total catch. Mexico is principal supplier of shrimp to U.S.

II. PACIFIC OYSTERS- $52,910,000$ pounds, with shells on, 9.2 percent of total production.

III. PILCHARDS - 41,887,000 pounds, 7.3 per cent of total production.

IV. GROUP OF SPECIES REDUCED TO FISH. MEAL-62,610,000 pounds, 11 percent of total production. 
eralized increase in per capita consumption. To achicve this, it is also essential that coordination and action be reflected in the strengthening of a massive and methodically efficient production, capable of meeting the nceds of the poorest regions of the interior of Mexico at reasonable prices.

The volume of fishing must increase to about 500,000 tons in the next six years for consumption to reach proper levels. The commercial value of this production at current prices will rise to two billion pesos, compared to 713 million pesos in 1963.

Encouragement of fish culture and sport fishing is another very desirable objective. Pisciculture can contribute effectively to improving the Mexican diet and diversifying the economies of regions with large, medium or small fresh water reservoirs. It has an excellent base in the responsible and patriotic labor of our technicians who, on the basis of prior studies, have made possible the introduction of formerly unknown species in our inland waters and control of propagation techniques of native specics. Sport fishing can be developed to make many parts of the country more attractive to Mexican as well as foreign tourists.

Ladies and Gentlemen: The leaders of the Revolution that gave Mexico its independence drew much inspiration from the triumph of George Washington and the thinking of Thomas Jefferson and Thomas Paine.

A breakdown of our fishing fleet shows 9,351 boats of less than three tons, 640 of from three to ten tons, 1,219 from ten to 50 tons, 305 of from 50 to 100 tons, and 26 of more than 100 tons.

Of this total, 1,341 boats, with a commercial value of 485 million pesos, constitute our deep-sea shrimp fleet. One of our chief concerns will be to encourage the training of fishermen to improve fishing operations.

The average age of boats larger than three tons is eight years, and are thus still capable of playing a major part in substantially increasing catches.

Investment in the fishing industry totalled 1.527 billion pesos in 1963. The shrimp industry accounted for 56.4 percent of this investment.

Of the assets of the fishing industry, 67.5 percent pertained to private enterprise, 23.3 per cent to the public sector, and 9.2 percent to cooperatives.
By channeling a larger volume of credits to the industry, under more favorable terms than in the past, it will be possible for many sectors to improve techniques of the industry and thereby improve efficiency, while simultaneously strengthening the industry. During the past ten years the volume of financial resources available for the fisheries totalled 3,221,600,000 pesos, exclusive of short-term credits to the shrimp industry.

Mexico accounts for but 0.4 percent of the world fishing catch. Its averages of per capita fishing production, mean capacity per boat and annual catch per boat are well below world averages. This constitutes a powerful incentive for us to invigorate our efforts.

Our regional fishing resources are largely concentrated in the northwestern part of the country, which includes the states of Sinaloa, Sonora, Lower California and the Territory of Lower California. There shrimp and lobster, two of the most prized species of the Mexican coasts, are taken, as well as sardines, anchovies, mackerel and abalone.

This region atccounts for 65.8 percent of total capitalization, 87.6 percent of the shrimp fleet, 79.7 percent of fish processing plants and 74.7 percent of net investment. In the 1860 s, Mexicans staunchly supported that giant of history, that friend and brother to all men on earth, Abraham Lincoln, in the struggle he led to preserve that form and substance of government whose chief objective is to elevate the human condition and rid all men of their artificial burdens; to cleanse the streets so that all may attain objectives worthy of praise, and to give to all the opportunity for progress without hindrance. These lofty ideals hav'c also guided our own governments, sprung from the Mexican Revolution of 1910, whose action is oriented by the postulates of our Constitution of 1917 .

We Mexicans are aware that we are still a devcloping country and that we have within our borders some regions that are extremely poor. Nevertheless, we are convinced that our problems are far from being insurmountable, and that our creative ability affirms our determination to continue our advance along the path of economic development and social justice, in an open and frank atmosphere, toward international cooperation and a common attack on our common problems.

Our sincerest thanks go to you for your unforgettable hospitality and the opportunity you have given us to be with you during this magnificent meeting. Muchas gracias! 


\title{
World Markets and Demands
}

\author{
by Stewart L. Udall \\ Secretary of the Interior \\ Washington, D.C.
}

Mr. Chairman, Distinguished Guests, Ladies and Gentlemen: I am grateful for the invitation to meet with you today to discuss a subject of growing importance to all of us-World Markets and Demands.

In the short time available, we can take only a broad riew, possibly identifying some of the key factors in world demands, and the hopes of all people for a better life. I propose to outline some of the major forces bringing changes in the world market and to indicate the challenge that world trading presents to the North American fishing industry.

The stark realitics of nuclear-age politics compel most leaders to be world-minded. The United States is committed on all continents to a struggle to demonstrate the benefits of a free society.

President Johnson in his State of the Union Message expressed this so well when he said, "For today the State of the Union depends in large measure upon the state of the world. Our concern and interest, compassion and vigilance extend to every corner of the dwindling planet." To emphasize his interest the President has proclaimed this to be a year of International Cooperation. The concern and interest of the North American Fisheries also are worldwide. Markets no longer are isolated. The world market is available and at the same time the domestic narket is part of the world market.

I would like to discuss world demand for fishery products in two parts. Let us look first at the present effective world demand-that is, the consumer demand coupled with purchasing ability that creates international trade. Then I would like to turn to that part of the world population which does not have the money to buy what it needs.

World fish production and consumption have doubled every 10 years for the past several decades. The world catch of marine fish was about 25 million metric tons in 1955; today it is about 50 million metric tons and is expected to increase significantly in the foreseeable future. However, the North American fisheries catch has not kept pace with the increase in world catch. In 1953 North America produced about 14 percent of the world supply of fish, while in 1963 North American nations took only 9 percent of the total world catch. The main reason for this is the fact that many countries have become aware of the increasing potentials for food production from the sea. For example, Japan and the Soviet Union launched vast high seas fishing fleets during the past decade, while the North American fisheries have confined for the most part their efforts largely to traditional waters. The countries of North America and Europe have been leaders in introducing technological developments for better utilization of catches but increases in fishery production have been far less spectacular. Fishery catches in North America increased only 16 percent between 1950 and 1962. The increase in Europe was 38 percent. In contrast, an increase of 1,500 percent was achieved in Latin America, 150 percent in Africa, 130 percent in Asia and 120 percent in the Soviet Union.

Granted, the increase in Latin American production has been mainly in anchovy for the Peruvian fish meal industry. Nevertheless, the trends are significant-- the North American industry has not carried out a vigorous policy toward increasing the use of high seas fishery resources, while other nations have intensified their efforts. Our fishery industry has been largely static. However, there are indications of technological advancements which could spark a new growth.

International trade in fishery products is growing. The volume of world exports in 1963 was almost three times as great as in 1948 and was 60 percent larger than in 1958. In 1963, fishery exports of some 130 countries were valued at more than $\$ 1.5$ billion, 50 percent higher than 1958 .

The importance of purchasing power in developing new world markets is reflected in the pattern of world trade. North America and Europe combined, bought about 83 percent of the total volume of world imports of fish in 1963. In contrast, Africa, Latin America, and Asia together-countries with a relatively low purchasing power-accounted for only about 14 percent of the world import total.

As incomes and populations grow in North America and Europe, there is a pronounced increase in the demand for fish. However, equally important is the change in the type of products desired in these countries. Rising incomes are reflected in a demand for higher priced products. As a result of this shift, producers of the lower valued products are seeking and finding markets in some of the lower income areas of the world. This tendency for a change in income to be reflected in consumption patterns is a significant factor for the North American fishing industry to keep in mind. And the European Common Market has potential for further increases in per capita disposable income. Thus we can expect increased demand from this market area for such high valued items as crab, lobster, and shrimp, the more desirable species of groundfish, salmon, halibut, and the flatfishes. 
Technological developments in processing and product form have had an important impact on world trade in recent years and likely will be just as important in the future. The development of the cold-chain has resulted in an increasing proportion of fishery products moving to market in fresh and frozen form. Trade in dried, salted, and smoked fish has declined since 1945. This trend has been most pronounced in North America. However, it may well be onc of the most important developments in Western Europe in the next decade. The extension of the cold-chain to supermarket type of retail installations and to the home is just getting under way in Europe. Rapid advances will be made in the next decade and significant changes in product form and method of distribution of fish in Western Europe will result.

I have mentioned several factors that have been important in the recent expansion in the volume of world trade. Now I want to touch briefly on trends developing throughout the world to reduce restrictions in international trade, cspecially tariff and nontariff restrictions.

There is little question that international trade is important in helping developing nations to achieve stability and progress in freedom. It is also important that the flow of fishery products be channeled through world markets in a manner that will satisfy human wants and needs.

We are engaged in the Kennedy Round of Tariff Negotiations, seeking to reduce trade barriers on a reciprocal basis for the purpose of increasing international trade. In the United States, the Trade Expansion Act of 1962 gives the President the tools to effectively bargain down trade restrictions. However, I want to emphasize that the United States now has one of the lowest overall tariff schedules on fishery products in the world fishing community.

The Kennedy Round negotiations represent an opportunity to enlarge the benefits of trade for all nations of the free world. We in North America, as well as our counterparts in Europe and Japan, bring to these negotiations special and highly charged domestic interests, and unique within-country problems. No country will be able to gain all the advantages it would like. These negotiations are expected to continue through the present year and into 1966. They will be complex and difficult, for stakes are high involving vital economic interest of many nations.

From the standpoint of some individuals or industries, segments of the fishing industry, for example, action taken to free world trade poses immediate economic hardship. But the teduction in trade barriers, making possible frecr trade and opening new markets, I would hope, will provide a challenge to the American fishing industry which could very well in the long run more than offset immediate adverse effects.

Competition in international markets grows more vigorous as other trading nations enlarge their fisheries. As competition for markets increases so do international concervation problems increase, and the need for broad cooperation between nations to solve the present and foreseeable problems of the development, management, and conservation of aquatic resources, commonly fished by many nations, becomes urgent. If we solve these problems in the future, the fishing industry will pros- per; if we fail, we can only predict a further contraction of this vital industry. We would hope that the 1958 Convention on Fishing and the Conservation of the Living Resources of the Sea will soon come into effect to help in this effort.

\section{Potential Demand}

Now let us turn to the other part of world demand-that part which lies outside present commercial trade channels - not because the wants and desires are lacking but because the people do not have the means of purchasing the products to satisfy these desires.

It has been estimated that one half the world population today is hungry, and that over 500 million of the world's 3 billion people are actually suffering protein malnutrition. Inadequate diet can result in lassitude, susceptibility to infection. persistent mental retardation, and a number of serious diseases. It can also cause horrible disfiguring diseases in infants and children, robbing them permanently of physical strength and mental agility.

Protein deficiency exists in all of Asia except Japan and Israel, all but the southern tip of Africa, the northern part of South America, and almost all of Central America, and the Caribbean countries.

The low income countries of Latin America, Asia, and Africa make up half the free world's population. They have massive economic and social problems and a shortage of means to meet their aspirations.

In 1961, at the FAO International Conference on Fish and Nutrition, the representatives were challenged to provide sources of fish protein to persons in all walks of life in nutritive forms and within the range of all income groups. It is now clearly indicated that fish protein offers a practical way of getting the necessary ingredients into the diet of undernourished people of the world. Fish is a nutritious human food and some of its byproducts are a valuable additive to food for animals.

Some experts of marine resources believe that about 90-95 percent of the oceans' productivity is unused and that with proper management and conservation it can be increased at least ten-fold without endangering the supply. If so, the world's oceans could provide at least 500 million tons annually as opposed to the present 50 million tons. It was suggested by Dr. Larkin earlier in this meeting that the potential catch of fish from the sea is at least 500 million tons, ten times the present catch, and may in fact be as much as two billion tons, or 40 times the present catch.

Yes, the resources of the sea can provide valuable food to mect the problems of malnutrition throughout the world today. This is especially significant in view of the prediction that our food supply must double within the next 40 years to fecd the increased population.

The United States National Oceanography Program has, for the past five years, been accumulating the basic physical, chemical, and biological knowledge necessary for understanding the ocean and its resources. We are now ready for the ancillary supplemental program - the National Ocean Engineering Program-whereby we may translate this knowledge into effective 
application of engineering principles to the problem of effciently hariesting or mining the ocean's resources. The early implementation of ocean engineering studies is vital to achieving the full potential of available marine food resources and to increasing the efficiency of harresting fish which will enable industry to expand its position in world trade.

But in order to make this vast food resource available to hungry people we must have a more highly developed system of trade and aid - one which requires international cooperation as well as cooperation between governments and private business. This is one of the central issues at the heart of President Johnson's Great Socicty concept.

The President, in his State of the Union Message, stressed one of the goals of the Great Society when he said: "I will seek new ways to use our knowledge to help deal with the explosion in world population and the growing scarcity in world resources."

Through our overseas aid programs and especially through Food for Peace, we are seeking to encourage economic growth, improve living standards, and increase buying power among the hundred of millions of people in the developing countries of the world. Fish can play a decisive role in these programs.

Now you may ask the question-How can private industry help as long as this part of the world market lies outside commercial trade channels and is dormant? My answer to that would be-This latent demand is continually being stimulated and developed through the process of economic growth. Policies of both the industrialized and the developing countries have stressed the importance of continued and expanded economic growth of the less developed countries. Economic growth has become a major factor in maintaining political stability. As this economic growth takes place, people of these countries increase their income. As they increase their incomes, latent markets become active markets.

As these markets become active, we should be prepared to supply them with fishery products they want and can buy. These will not necessarily be the same "luxury type" products being used to satisfy the demand in North America and Western Europe. They must be low-priced products which are preservable and nutritious.

We need further work to develop products to meet this potential demand. We cannot supply this market with fresh fish; neither can we count on their being able to handle large supplies of frozen products.

Preservable products which are possibilities are the conventional canned and cured products. We also need continued research on the adaptation of new technology, such as freeze-drying and irradiation, as a means of solving this problem.

With very few exceptions, the manufacture of fish protein concentrate has not yet received the interest it deserves. Several countries, including the United States and some international organizations, have given increasing recognition to the importance of fish protein concentrates in improving the diet of people in countries where animal protein is lacking.

We are on the threshold of marked improvement in commercially and economically feasible methods of manufacturing fish protein concentrates. With this development, we can expect to bring into commercial use many species of fish not now utilized, and we will also most certainly see an upgrading in the use of some spceies now taken only for industrial uses. Within the past three decades, we have seen our own menhaden resource upgraded from use as a fertilizer to use as a valuable protein supplement in animal and poultry feeding. The next step will be upgrading products from this resource from an animal feed to a protein rich additive to the human diet.

Off the North American coasts abound large stocks of hake, mackerel, and certain herringlike fishes scarcely utilized today. Production could be increased many times if such species were caught up to the limit of their sustainable yields. We should no longer ignore this bountiful natural resource because of lack of marketability, but rather we should strive to develop methods to make these species available for the market. A large step in the right direction is being made in the northwest, where I understand a hake fishery will be started this year.

In conclusion, let me sum up the challenge that world markets and demands pose to the North American fishing industry. World trade in fishery products has been expanding rapidly and has been undergoing significant changes in terms of products and product form moving between countries. Thus far, the United States fishing industry has not taken advantage of the opportunities for developing export markets for fisheries products. In fact, in the postwar era we have lost some of our prewar markets. Many of these because of conditions beyond our control. There can be no doubt but that expanded world markets for American-produced fisheries products present a dynamic challenge to the American fishing industry. Consider for a moment the continued economic development and a potentially improved environment for world trade which offer the possibility of even greater increases in trade in the next decade. There are significant advantages to be gained by the North American fishing industry from this expanding market if we work to take advantage of the opportunity. If we can improve our technology and efficiency in harvesting and processing of fish, and merchandise our products aggressively in world markets, we can increase the net revenue from our fishery resources and at the same time extend the volume and species of fish taken by our industries.

In addition to the expansion of the present effective demand, there is a great potential for extending the market to lower income areas of the world, where the purchasing power is currently lacking. Here again we need to seek the means of harvesting and processing to provide a nutritious product that can be brought into the price range of the lower income areas. We are close to a great development in the fish protein concentrate program. This new technology has within it the means to bridge the gap between the vast untapped resources of the oceans and the dire need in large areas of the world. So, I say, let's not despair about present difficulties but rather take heart in the great opportunity available to us; few industries there are in our country which possess such potential growth possibilities; let us aggressively look for ways to take advantage of the developing vast world market.

Thank you very much. 


\title{
The Role of FAO in World Fisheries
}

\author{
by Roy I. Jackson \\ Director, Fisheries Division \\ Food and Agriculture Organization of the United Nations
}

First, I would like to say what a pleasure and honor it is for me to be here. I recently ended niy first year with the Food and Agriculture Organization of the United Nations in Rome. It is a privilege to be able to mark that first anniversary by helping to establish this other "first"- the First North American Fisheries Conference.

This year the Food and Agriculture Organization celebrates another anniversary, its twentieth birthday. In many ways the figure reflects some truth-we are emerging from adolescence and are about to come of age. In many other ways, and in terms of problems faced and storms weathered, both FAO and the UN are rather ancient and worldwise institutions already.

My topic-FAO's rôle in world fisheries-is a large one. First I intend to review some of the major elements in the world fisheries situation. The story there is change, expansion and increased catches. My second major point will be an attempt to show how this change and expansion gives more and more of an international character to what was once a more or less localized industry in most parts of the world.

I want then to mention the part that FAO and its Fisheries Division play in this international movement. Finally gentlemen, I want to outline some very current ideas for improving and enlarging FAO's rôle in world fisheries, ideas that are now being debated in the international forum.

In talking about world fisheries, especially to practical people from the industry, there is no better reference point than production. In 1963 the marine and inland waters of the world produced something more than 46 million metric tons of fish, or about 100 billion pounds. Most of this catch was taken in international waters where fishing is almost completely uncontrolled. Here, what you take depends only on your skill, gear, good fortune and markets. The resulting catch distribution is rather interesting.

First, nearly one-third of the 1963 world catch was taken by two countries-Peru and Japan. Second, the top two-thirds of the world catch was taken by only ten countries. Finally, 95 percent of the world catch was taken by the leading 42 fishing nations.

Forty-two countries. Good. However, there are in the world about 220 countries, dependent or independent.
But some countries have no marine fisheries. Others--such as the Vatican City-have no fisheries at all. Taking this into consideration, the fact remains that perhaps 165 or 170 countries - a majority of countries with millions of fishermen - must share only five percent of the world catch. Perhaps as many as 120 countries, nearly half the countries in the world each produce less than 5,000 tons of fish a year from both marine and inland waters.

A look at the regional distribution of the catch shows that most of the traditional fishing grounds are in the north temperate zone. One of our staff in Rome calculates that an average Icelandic fisherman accounts for an annual catch of a good deal more than 100 tons, while the average tropical fisherman will take about one ton a year. According to this, the technology of the advance nations puts them at least 100 times ahead of the developing nations from a production viewpoint.

Again, we see this imbalance in sharing food from the seas by matching the oceans against their production. The Pacific, with 50 percent of the earth's sea water area (including adjacent Arctic and Antarctic waters), produces a little more than 50 percent of the world catch. The Atlantic (including the Mediterranean and Black Seas), with 30 percent of the sea area. produces a little over 40 percent of the fish. But the Indian Ocean, with 20 percent of the world's sea surface, produces considerably less than 10 percent of the world catch.

By rearranging these ocean catch figures roughly according to production by climatic zone, we see that waters such as the northwest and northeast Atlantic and Pacific, including the Mediterranean and Black Scas-northern waters in other words-provided nearly 60 percent of the marine catch. Tropical waters such as the west-central Atlantic and Pacific, the Caribbean and the Indo-Pacific regions, produced only: 17 percent. At least some of this must have been taken by northern fishermen with their factory trawlers and motherships, far south of their home ports and traditional grounds.

Almost the entire remainder of the world marine catch was anchovy-another sign of the change sweeping through the world industry-a change that has lifted Peru from obscurity as a fish producer to the top of the production heap in a dozen years. 
Since 1958, the amount of fish for reduction to meal and oil has increased by 180 percent. This brings us to the subject of fishmeal.

In 1958, 13 percent of the total world catch was used for reduction. By 1962 , this figure had risen to $261 / 2$ percent, even though the world catch itsclf had greatly increased. The trend continued upward through 1963. If we exclude the world inland catch, the proportion of sea fish used for reduction is nearly 30 percent.

It would seem that at least one of every four tons of fish caught is not used directly to feed human beings, but is ground into meal to feed pigs and chickens, eventually to appear on the tables of nations which can afford this expensive food. This should not be taken as an indictment of the use of fish as a source of meal for animal feeding. Rather, when we look at present and future problems of hunger and malnutrition in the world, the existence of vast stocks of fish now used for meal for feeding animals challenges us to find ways in which these proteins can be brought to the people in developing nations who need them so desperately. FAO is deeply involved in the problems of promoting human consumption of fish protein concentrates.

I have been trying to make several points about world fisheries today. The usual, and quite valid, summation is expansion-bigger catches, bigger boats, more of everything, fisheries being swept along in a technological revolution. It is said that world fishing has advanced more in the past 20 years than in the previous two thousand years. But there are places and people-overwhelming majorities of fishing nations and fishermen which have been left far behind. One result is that 95 percent of the world catch of fish is taken by one-fifth of the countries. Another result is a tremendous technological disparity shown by an Icelander's 100-ton annual catch and a tropical fisherman's one ton. And in the midst of this, special problems such as the fishmeal explosion, which make the world catch look much better than it really is in terms of this tremendous dilemma that the world is in over human feeding. These problems are foremost in FAO's rôle in world fisheries.

I have been restraining myself from plunging into a subject which raises its head at almost every point. It is a new element, new certainly in degree. I consider it the most important aspect of modern world fishing. It is internationalism, the increasingly international character of world fisheries.

At FAO we have some rather good statistics on international trade. If we convert the fishery products entering international trade to their original live weight equivalent we find that one-third of the total world catch was entering international trade seven years ago. Since 1962 this figure has risen to 40 percent. For every fize tons of fish caught, two are exported. The volume of fish and fishery products traded internationally is now more or less the same as the amount of meat.

Of course, the basic underlying factor, the way in which fisheries differs from agriculture, is that the high seas and their fish stocks are the common property of mankind. This fact, coupled with rapid advances in the range, speed and fishing power of the world's fishing fleets, and with improved tech- nology of preservation has brought nearly every portion of the world ocean under exploitation. The southern seas, almost untapped a few years ago, are now being worked by vessels from many countries. Every ocean seems to become smaller. Each new factory trawler is more efficient than the last.

There are many international and intergovernmental bodies dealing with fisheries. Most are concerned with the fisheries of particular regions, of ten with particular species or groups of species. Some deal with research only, some with regulation of fishing effort, some with jurisdiction. In a typical year our Fisheries Division will have active liaison with two or three dozen international bodies dealing with fisheries in one way or another.

As pressure on aquatic food resources grows so does the role of FAO in world fisheries. There is at present a good deal of discussion and debate going on about our place in this modern, highly internationalized fisheries situation which $\mathrm{I}$ have been describing. Perhaps we could backtrack a little to inquire what $\mathrm{FAO}$ is and does.

FAO grew out of war. The idea was discussed in 1943 not far from here, at Hot Springs, Virginia. It was probably one of the most noble and generous ideas ever conceived by man. Basically it boiled down to this: most people are hungry and undernourished; try to feed them and raise their nutritional level; show them how they can help themselves.

Sickened by war, people wanted no more of it. It was clear that peace is difficult to achieve where there is great inequality in eating standards, living standards, health standards and income levels.

The result was that, shortly after the United Nations itself was founded in 1945, its first specialized agency was createdthe Food and Agriculture Organization of the United Nations. The founding meeting was held north of here in Quebec City, Canada, and FAO's first headquarters were right here in Washington.

One hundred and twelve nations now belong to the Organization.

The FAO Fisheries Division now comprises 53 professional officers, including 10 fishery officers at seven regional offices around the world. We divide our work into two broad categories. The first category, work under the so-called Regular Program, has always been with us. This is mainly work of coordination and leadership in collecting and disseminating technical information on fisheries. The expression of this work is seen in our convening of scientific, technological and economic conferences, seminars, study tours and working groups. The e gatherings pool the world's knowledge on certain specific fisheries subjects. Another expression of Regular Program work is our publications and documents program in which fisheries information is produced and distributed in FAO's three working languages, English, French and Spanish.

An important part of our Regular Program work consists of efforts to promote conservation and wise use of fisheries resources. At the moment we are contributing our efforts to those of many others on a most interesting and difficult case in point - the conservation of whale stocks, particularly in the Antarctic. 
Today FAO representatives are in London before an extraordinary meeting of the International Whaling Commission to present the results of our scientific assessment of the woeful state of Antarctic whale populations. If I were not here, I would be there to help in a search for more sensible international whaling policies.

At present, the humpback whale, and the blue whale-the largest animal ever to have lived on earth -are both nearing commercial, if not actual, extinction. Both species are now protected, but only time will tell whether this action has been taken too late.

The estimated number of blue whales in the Antarctic before I940 was about 140,000. The stock size in 1954 was estimated to be between about 10,000 and 14,000. In 1963 the estimated Antarctic stock of blue whales had declined to between 650 and 1,950 whales. Any further whaling for this species now will send it the way of the dodo and the passenger pigeon. But given sufficient time to rebuild, there may be still some hope that in the distant future, the world will once more be able to count blue whales among its food and industrial resources.

The reason that blue whales have all but ranished from the seas and that other species may ranish is that the whaling nations were unable to come to international agreement on a common and adequate conservation policy. If a scientific quota had been established and respected, the blue whale would not now be commercially extinct.

Under our Regular Program, we have sponsored and provide the Secretaries with technical advice for five regional international fisheries commissions, concerned with marine, and in some cases inland, fisheries of the Indo-Pacific Region, the Southwest Atlantic, the Southeast Atlantic, the Mediterranean, and the fresh-water fisheries of Europe.

We are acting as the center of efforts to establish an international body for providing a scientific basis for the utilization of the Atlantic tuna fisheries.

The other kind of work we do is technical assistance. The United Nations began technical assistance in 1950 with the formation of the UN Expanded Program of Technical Assistance, which we call EPTA. So far, our Fisheries Division has sent experts to more than 80 different countries. Some countries have been served by a dozen or more expert missions. In 1965, 46 more EPTA fisheries experts will be sent out from Rome. Technologists, economists, biologists, gear and vessel experts, engineers, master fishermen - all offer their skills to teach their counterparts how to solve fishery problems more effectively.

FAO also executes projects financed by the United Nations Special Fund. In contrast to EPTA work, projects under the Special Fund involve not single experts or small groups of experts, but whole teams. FAO takes on the greatest share of these large projects - about one-third the total number.

In fisheries work, the projects usually take the form of complete fisheries institutes, usually where nothing remotely similar ever existed. In these institutes, teams of internationally recruited experts, including industrialists, biologists, economists and technologists, tackle the main problems of the fishing in- dustry. But it is more than this. By teaching counterpart national staff, we are able to muster Government support for the institute. After four or more years, the international squad pulls out, leaving the country a strongly founded fisheries institute on which to build.

I am rather excited about nisheries work under the Special Fund since I have returned only a month ago from a swing through Latin America where we have several of these projects in various stages. I was tremendously impressed with what can be done under this plan. In most cases, we are helping to make over the whole fisheries apparatus of these countries.

In early 1965, FAO's Fishcries Division was responsible for seven such projects which are now in operation, involving about 15 million dollars, and another eight projects worth about 20 million dollars which have been approved but are not yet operating. Five more fishery projects are in preparation and there are 14 others under consideration.

Before I close there is one point more which I would like to explain. It concerns the ratio of international work that we should do as against the amount of work that we can do with our present divisional budget and staff.

The FAO Fisheries Division is at a crossroads. We cannot continue on the same path that we have followed since 1945. Somewhere along that traditional road, the expansion in international fisheries caught up with us and passed us by. Try as we might, our present staff and organization are just not set up to be able to cope efficiently with all the questions which demand urgent answers.

Within the next few years, for example, our work under the Special Fund alone is estimated at a dollar volume of 20 million dollars a year. To put this load on our present staff would crack our operation down the middle.

About two years ago, some action began to be taken on these matters. When the ruling body of FAO met in November 1963 at the Twelfth FAO Conference, the Fisheries Technical Committee noted that international activities related to the oceans were not organized in the United Nations family in a way to assure maximum effectiveness.

A Resolution by the Technical Committee was adopted by FAO's governing body. It asked the Director-General of FAO, Dr. B. R. Sen, to prepare proposals for consideration by the FAO Council and Conference, outlining ways to give FAO and its Fisheries Division leading status among intergovernmental bodies in encouraging rational harvesting of food from the oceans and inland waters.

The Director-General has responded with a proposal consisting of two equal and interrelated parts. First, the creation of a permanent high-level advisory Committee on Fisheries consisting of selected Member Nations. Second, the elevation of fisheries from that of a Division in the Organization to that of a Department, initially of two Divisions. The Committee on Fisheries will consist of 15 to 24 Member Nations represented, we suggest, by high-ranking fisheries officials. The Committee would advise FAO on its fisheries programs and would also conduct general reviews and appraisals of fishery problems of international character. 
The FAO Department of Fisheries would be approximately double the size of the present Division after six years of orderly growth and development.

These expansion proposals are still, of course, just thatproposals. The meeting that could make them a reality is the Thirtecnth Session of the F $1 O$ Conference which meets in Rome this November. Should they happen to be accepted, about one-third of the expanded program will take effect in the next two years.

Naturally, I and my whole staff in Rome are quite excited about these possibilities. If events go as we hope they will, we shall be prepared for even greater challenges and opportunities that will appear on the international fisheries scene.

Nearly all its Mcmber Nations fecl that FAO has a strong and significant rôle to play in world fisheries desclopment. Not the rôle of a superpower, a regulator of fisheries or a dictator of policies. Rather, the rôle of leadership through service: the collection and dissemination of scientific information, technical assistance, the promotion of rational use of resources, particularly those of the high seas through the promotion of coopcration between nations fishing international waters, the promotion of efficiency and economy in the use of fish and its products, always to the end of the alleviation of hunger and disease. These are difficult, challenging and worthy aspirations. There is nobility in the concept and aspirations of FAO, as there is elsewhere in the UN family. But, I submit, a kind of practical and rational nobility-to help every man feed his children as well as you and I would feed ours. Not to share in scarcity but to promote plenty. The seas and inland waters covering nearly three-quarters of the earth's surface will play a rôle in human survival and welfare whose importance we can only begin to estimate.

I hope I have left you with a better idea of the rôle of FAO's Fisheries Division. I would consider myself successful if you were to share my interest, at least in part, in those tremendous new possibilities for the expansion of this urgent work in international fisheries.

Once again, please accept my thanks for the opportunity to present these thoughts to such a significant gathering. From what 1 have seen and heard here, and from the impressive way in which your meeting organizers have done their jobs, I should hope to attend many more North American Fisheries Conferences.

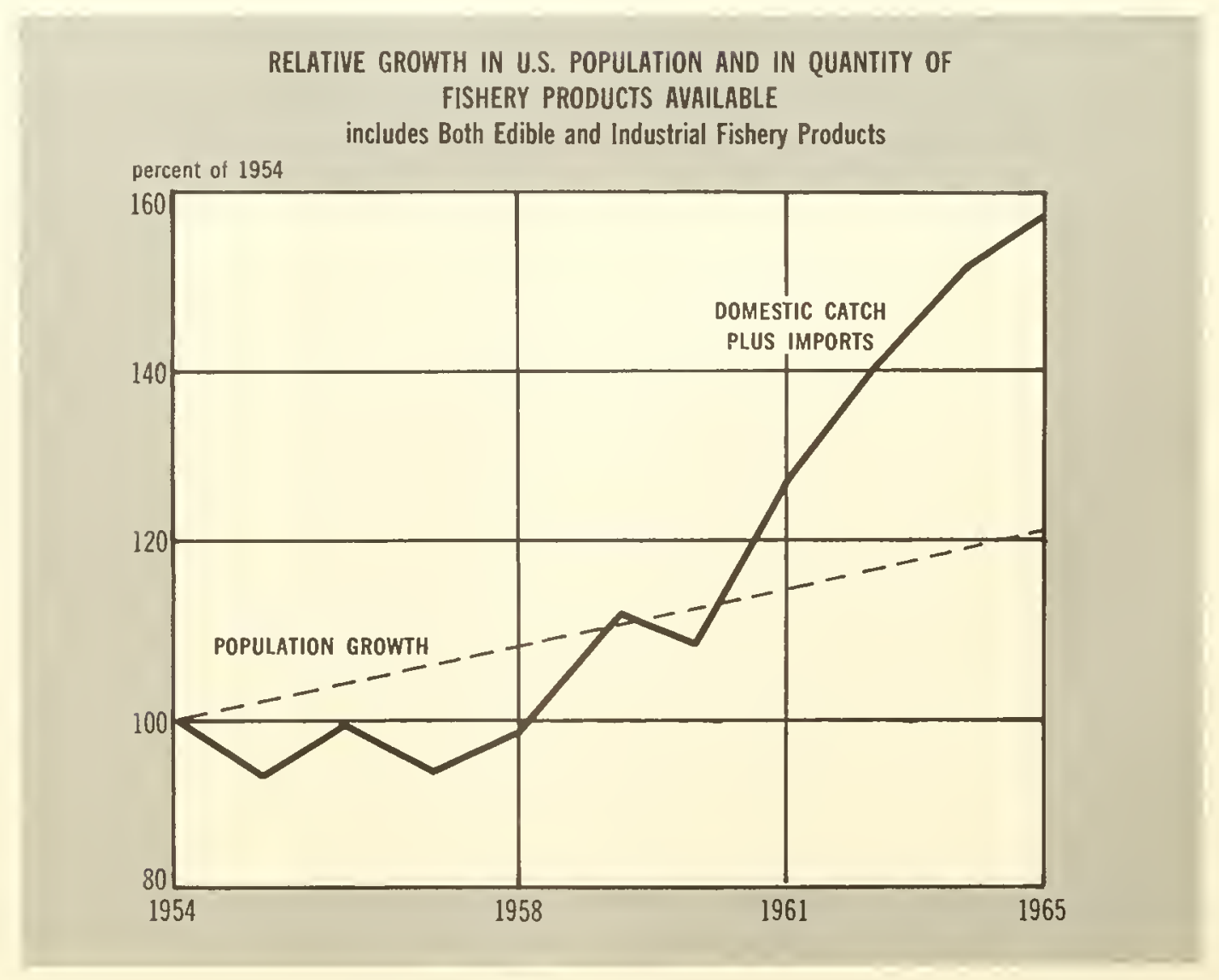




\title{
Summary of Conference
}

\section{The Future of North American Fisheries}

\author{
by Donald L. MeKernan \\ Director, Bureau of Commercial Fisheries \\ United States Department of the Interior \\ Washington, D.C.
}

I have been given the honor of summarizing the papers presented at the Conference. I have found the past three days' discussions in the general sessions so stimulating and so thought provoking that the opportunity of having the last word about subjects so close to our hearts has stimulated me thoroughly.

In discussing the future of North American fisheries resources, we have quite properly considered first the North American fishery potential. In this consideration, Dr. Peter Larkin reviews some of the background of world fisheries production, compares this with current and potential North American production, and points up clearly some realistic concepts in achieving and sustaining this potential.

The next two speakers, Drs. Kask and Chapman, posed both questions and answers relating to the key issues raised by citizens, industry, participants, politicians, and governments. If, as Dr. Larkin states, the potential of food production from the sea is far greater than now realized, Dr. Kask asks how can this potential be reached? How can the countries of North America participate more actively in utilizing the resources of the world ocean? What problems face these countries in reaching their goals? And what measures need be taken to improve the possibilities for success in increasing fish production at a profit? Obviously, such a discussion of the potential resources of the sea and our thoughiful inquiries as to how we can achieve improved production leads next to the problems of harvesting, processing, and marketing.

Dr. Schaefer has discussed the role of the study of the oceans in the harvest of the resources, and Mr. Basil Parkes has added both constructive and practical suggestions about future improvements in fish harvesting. He also raises, from a practical point of view, the urgent need for effective conservation regulations and enforcement on an international basis.

But our questions have probed far beyond this point, and so have our inquiries in this meeting. After considering the resources, the role a study of the oceans can play in improving the harvesting of these resources, and ways of improving our present fish-harvesting methods, Mr. E. Robert Kinncy discussed the need for and possibilities of keeping the catch in good quality. He also raised the question of processing fish better and in more ways which will make it attractive to the con- suming public. But even the processed product must be marketed, and Minister Sharp, the Fish and Seafood Promotions Division of the National Fisheries Institute-including speakers from various segments of the industry-and Secretary of the Interior Stewart L. Udall have examined, and in an optimistic vein I might add, the potential markets within our own countries and abroad and the need for opening these markets more widely.

One can only conclude from the discussions of marketing that opportunities are present and, if one is not careful, we might be lulled into a false sense of security. Dr. Kask, on the other hand, points out in the early questions raised by him that, despite the potential resources available, the consumption of fisheries products in our countries has remained low and has failed to keep pace with the increased consumption of meats and poultry.

Several speakers mentioned the developing international scene, and Minister Robichaud as well as Mr. Jackson have raised the unique and urgent problems posed by man's race for the resources of the sea. Jackson pointed out the unique role which he believes FAO can play in resolving the conflicts arising among fishermen of various nations harvesting common resources.

I am impressed by the breadth of our discussions, the penetrating questions raised by our speakers, and the imaginative, although sometimes embarrassing, questions which have been raised but by no means completely answered as a result of our discussions.

I should like, in the few minutes allotted me, to discuss more fully the general course of these discussions as I have followed them, and while I presume I should act as a mere reporter, I do not find it possible in my heart to refrain from adding my own views. Thus, I hope I will be forgiven if my reporting and summation of this Conference are shamelessly colored by some of my own prejudices. My only excuse is that perhaps by this means I can bring together what seems to me to be the main streams of thought brought to this Conference by our previous distinguished speakers and perhaps make the various discussions tie together into a recognizable picture.

One must accept the consensus of our speakers that there 
is an unused potential of fish products in the world ocean and that it is probable we can increase the fish catch near the shores of our respective countries, using cxisting methods and available gear, by a factor of from two to four times the amount of fish now bcing produced by our industrics. It has been pointed out that this potential increase in catch is not a certainty but only a possibility-at possibility which can only be achieved with certain changes occurring among the habits of our people, policies of our Government, and action by our industry.

It was pointed out by Dr. Larkin that our North American fishery potential will largely depend upon what the consumers decide. He believes there to be a substantial demand for seafoods but that the full potential can be achieved only if the consumer wants it. Dr. Larkin further points out that the concepts of fisheries management are rapidly changing-from those which in the past were considered the maximum sustainable yield alone to a more sophisticated approach to conservation and management, which considers the maximized cconomic yield or the greatest value of production from the least effort within prevailing circumstances

I agree with Dr. Larkin that there is a great potential in the world ocean and that the North American Continent is in a favorable position with regard to the fisheries productivity. It seems rather obvious that our quite specific and unchanging tastes in fisheries products have limited the catch to a very few of the available species. At some time in the future, when we have leamed to efficiently catch and process our latent resources in a usable yet new form, prepare them for customers who have been conditioned to demand new products, products from herring, codlike and flounder species now lying fallow on and over the edge of the Continental Shelf, then and only then is it likely that our fishermen will be encouraged to turn their efforts to these species.

There can be no question about the demand. I bclieve that the greatest fisheries market in the world exists within our three countries. In fact, there is little question but what the United States by itself is the world's most important fisheries market, dollar-wise at least.

We in the United States are importing 62 percent of the fisheries products consumed in our country. If we can learn how to efficiently harvest and process the underutilized species adjacent to our coast, we can increase the consumption of our domestically produced fish. I believe this can be done without reducing the imports; it can be done by increasing the consumption of fish within the United States. To date we have been unsuccessful in increasing the per capita consumption of fish and some of our speakers have raised questions about this lack of success and others have pontificated about how we might overcome our difficulties.

Dr. Kask raises some of these important questions. He asks, "Why, when world fish production has more than doubled in 1950, have the North American fish producers barely held their own in spite of the fact that effective demand for fish products has continued to increase?" Secondly, he has asked, "Why hasn't the per capita consumption of fish improved along with the consumption of hread, mcat, poultry, eggs, and cheese?"
Thirdly, "Is one of our problems the overadministration of our resources?" - that is, the basic administration of the States are overlaid with the administration of the Federal Government and international commissions. He summarizes this question by asking. "Are we doing the right things with the increasing funds we are spending?" And, fourthly, "Can we justify the increasing costs of national research programs in the face of the lagging developments of North American fisheries?" These are important questions. They touch upon the heart of the problem. He might also have asked whether our present systems of dealing with developing international fisheries problems are entirely adequate, and he might have gone further and asked, "Are our concepts of, and mechanisnis for, the conservation and utilization of the living resources of the sea adequate for the future?"

Dr. Chapman, in discussing these questions, docs so somewhat indirectly. Perhaps he purposely avoids the direct questions asked by Dr. Kask. He addresses himself to the general question of "Politics and the Marine Fisheries." He discusses in some depth the problems involved in the full use of the living resources of the sea. Just as Dr. Kask's primary question involved the broad question as to why the United States and Canada, especially, have not increased fish production despite the effective and increasing demand for fisheries products in their countries, so Dr. Chapman has approached this broad question from the standpoint of what he calls "institutional problems," barriers our society has raiced to the fuller use of fishery resources off our coast. His paper points out, among other things, that the manifestation of our problem is the inability of fisheries products to compete with other products, such as the red meats, poultry, etc., mentioned by Dr. Kask, for the consumer's dollar. A number of these institutional problems are proposed as major barriers to the increased domestic catch. State laws which discourage the development of new fisheries and inhibit the efficient growth of existing fisheries are listed as being a major cause. The country-wide question of sportsmen versus commercial fishermen, and the inefficient versus efficient fishermen, both tend to inhibit the opportunities of American fishermen. It was pointed out that many of these conflicts are forms of gcar conflict, wherein a less efficient user of the resource wants to prevent a more efficient user from gobbling up the allowable catch, whatever that may be. While Dr. Chapman's contention seems to be that the recreational fisherman must always win out, I am not so certain of this conclusion. I would wonder whether the public interest in some areas does not lean towards making the healthful food products of the sea available to all citizens rather than to a selected few. Obriously, these resources can best be madc available to all citizens through the medium of efficient, modern, commercial fishermen. Nevertheless, Dr. Chapman's point that these are problems is well taken.

It is also true that the critical conflicts for the use of species of fish are few, and if reason rather than emotion was applied to the problems, solutions could easily be found.

Dr. Chapman points out that State fisheries research agencies and the academic institutions, as well as the Federal organization of ocean rescarch, all leave much to be desired in bringing 


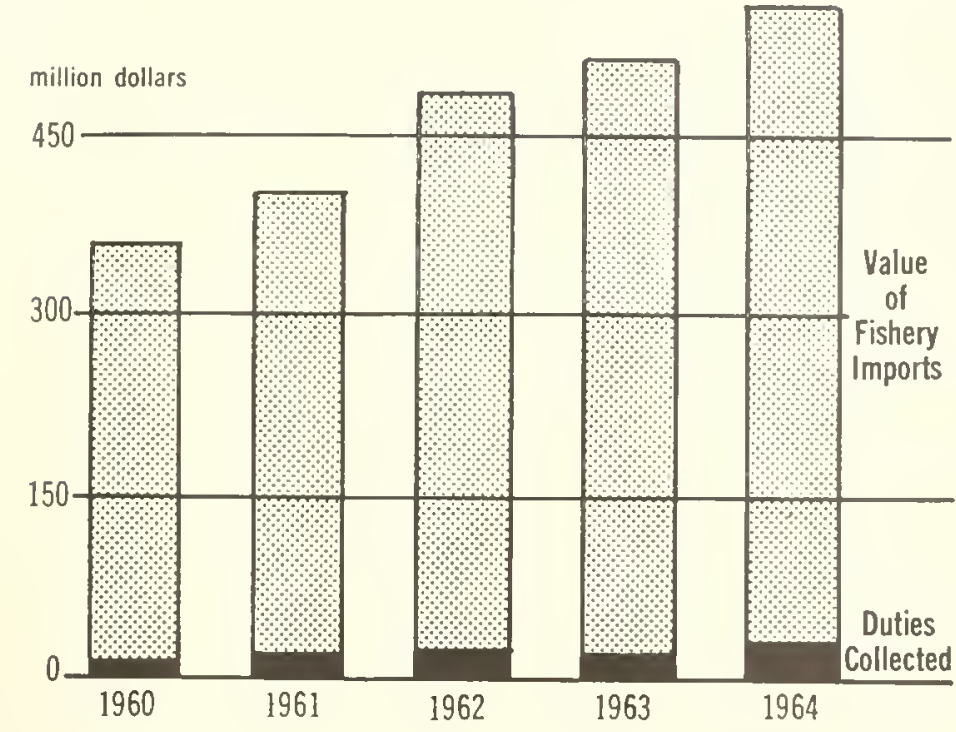

together information which could bear upon more logical conservation regulations and upon the more efficient capture of fish. He presents a rather bold and new approach to the Federal organization of fishery research in recommending a Department of the Oceans, composed of various civilian agencies having an interest in the sea. He points out that this civilian agency would provide for the civilian sector a function parallel to that which Nayy's oceanographic program provides for defense. He points out, essentially, that the National Science Foundation is well suited to promote adequately the ocean activities of academic institutions, but what is needed is a Cabinet-level organization within the Executive to stimulate the coordination and development of research and use of the ocean's resources for the civilian economy.

Dr. Chapman does not for one instant question, as Dr. Kask does, the present expenditures of funds for research. He expresses the belief that the expenditures are too low and that State fisheries research agencies as well as academic fishery research groups should be strengthened both in staff and financing. His answer to Kask's question about the justification of present expenditures of research is that we need more research, and if more dollars are spent along these lines we might expect dramatic results such as have occurred in agriculture during the past century. He also tend s to answer the question raised by Dr. Kask about the success of present fishery management efforts by indicating that there needs to be a general overhaul of this function within the States, a greater use of research results, and a willingness of State legislatures to leave to the specialists the job of conserving the resources.

He considers that, if we are to compete in the American food market, the cost per ton of fish must be reduced by the greater application of science and technology, along with overhauling and eliminating State laws which have no factual basis nor conservation effect. He would strengthen State and academic fisheries organizations, and would reorganize the ocean research and development in the Federal establishment.

Lastly, he has little sympathy for the proposition by many that the jurisdictional fisheries limits of the United States should be extended. His view, quite obviously, is that the Anserican fishing industry - with the proper application of money, brains, and existing scientific and technological information-can compete successfully with fishermen from any other country for fishery resources on the high seas and ought to start doing so.

Dr. Milner B. Schaefer, in discussing ways in which the study of the oceans-oceanography-can contribute to the increased catch of fish, quotes optimistically from a recent National Academy of Sciences-National Research Council publication to the effect that we could double our fish catch within the next 10 to 15 years and quadruple the overseas fisheries within the next decade. He develops the thesis that oceanographic research is one of the essential elements in realizing thesc potentials and he lists five ways in which oceanographic knowledge will assist in increasing the harvest of the sea. First, he points out that until recently, fishing grounds were discovered in almost a haphazard fashion, at least by trial-and-error means, but that a knowledge of the ocean currents and ocean environment may well lead to the rapid location and development of rich, new fishing areas.

Secondly, he points out that even in areas where commercial fisheries have long been exploited, systematic studies of current systems may well lead to major new discoveries. He uses as an example the discovery and delineation of the standing stock of some 2 to 4 million tons of anchory, which he claims could sustain a harvest of perhaps a half-million tons a year or more off the southern coast of California. He cites other examples on both coasts to indicate that careful, systematic oceanographic studies in existing fishing areas have provided information leading to the development of more efficient use of these resources or to the discovery of entirely new resources not understood to have been present in abundance previously.

Thirdly, Dr. Schaefer points out that a knowledge of fish behavior in relation to ocean conditions and properties in the ocean environment can lead to more efficient capture. There is no question about the fact that fish, being cold-blooded animals, react more specifically to their environment than do warmblooded animals of the sea or land, and that a knowledge of such simple parameters in the sea as temperatures has been shown to be a tactical advantage to fishermen. He points out that albacore fishernen off the North Pacific coast and cod fishermen in the North Atlantic have used the distribution of temperatures in certain layers of water to find concentrations of fish. Dr. Schaefer cites the almost obvious relationship between harvestable fish and aggregations of food supply as being a useful tool which fishermen might in the future use to improve fishing operations, although he recognizes these relationships have not been well developed.

Fourthly, Dr. Schaefer recognizes that a knowledge of the oceans is giving us information on predictability, and that variations in ocean conditions provide a forecast of expected good or poor runs of fish in many circumstances. He believes that a knowledge of the oceans will provide a basis for rational 
management of heavily exploited fisheries and this cannot be debated. Obviously, if we can predict the large and small runs in advance of the fishing season or trip with sufficient accuracy, conservation regulations and commitment of funds and labor can be tailored to the size of the runs.

Dr. Schaefer's view, in summary, is that, with the proper application of ocean science, fishing can be put on a more efficient basis, leading from the hunting economy of the past towards a systen of fish husbandry in the future.

The discuscion by $\mathrm{Mr}$. B. A. Parkes, a ressel operator from Hull, England, was refreshing. The British have had a history of long and successful experience fishing the eastern North Atlantic with constant and intensive competition from their neighbors in Europe. In addition, they have developed distant-water vessels to fish the North and Northwest Atlantic. Thus, their experience is of great value to us, especially at this time when many of us in North America are contemplating the construction or reconstruction of major segments of our fishing flects, and what is more important, some of us are looking to the North Atlantic. Unlike some of the preceding speakers, Mr. Parkes sounds a word of warning with his discussion of the efforts of the British to develop the most efficient vessels and more efficient gear in order to maintain their harvest from the sea; he points out that the catch per unit of effort of the trawlers has declined 30 to 40 percent in recent years despite the improvenent in ships and gear. One must recognize that the British developments in fisheries in recent years have been somewhat different from those in Japan and the Soviet Union. The British, rather than develop new fishing grounds and new fishing methods in other parts of the world, have tended to remain on their well-known and established grounds, expending their energies towards making their fishermen, vessels, and equipment more efficient. In this respect, I consider them to be perhaps the most advanced fishing nation in the world.

Mr. Parkes has done us the great favor of discussing the development of the distant-water trawlers of several types, including stern-ramp trawlers-and he points out that there soon will be 20 or 25 of these in operation. His discussion of the experiments in icing, freezing, superchilling, and filleting aboard these new vessels indicates quite clearly the systematic efforts of the British industry to maintain a competitive position on the North Atlantic fishing grounds and on the world

Crew of BCF research vessel Albatross IV retrieves fishing gear off Georges Banks during experimental fishing operations. Vessel has many new design features: stern trawling ramp, bow thruster to help control it on station, variable pitch propeller, active rudder, and closed circuit television. TV shows operations on vessel and trawl and other gear. BCF has 20 vessels capable of oceanographic and fisheries research.

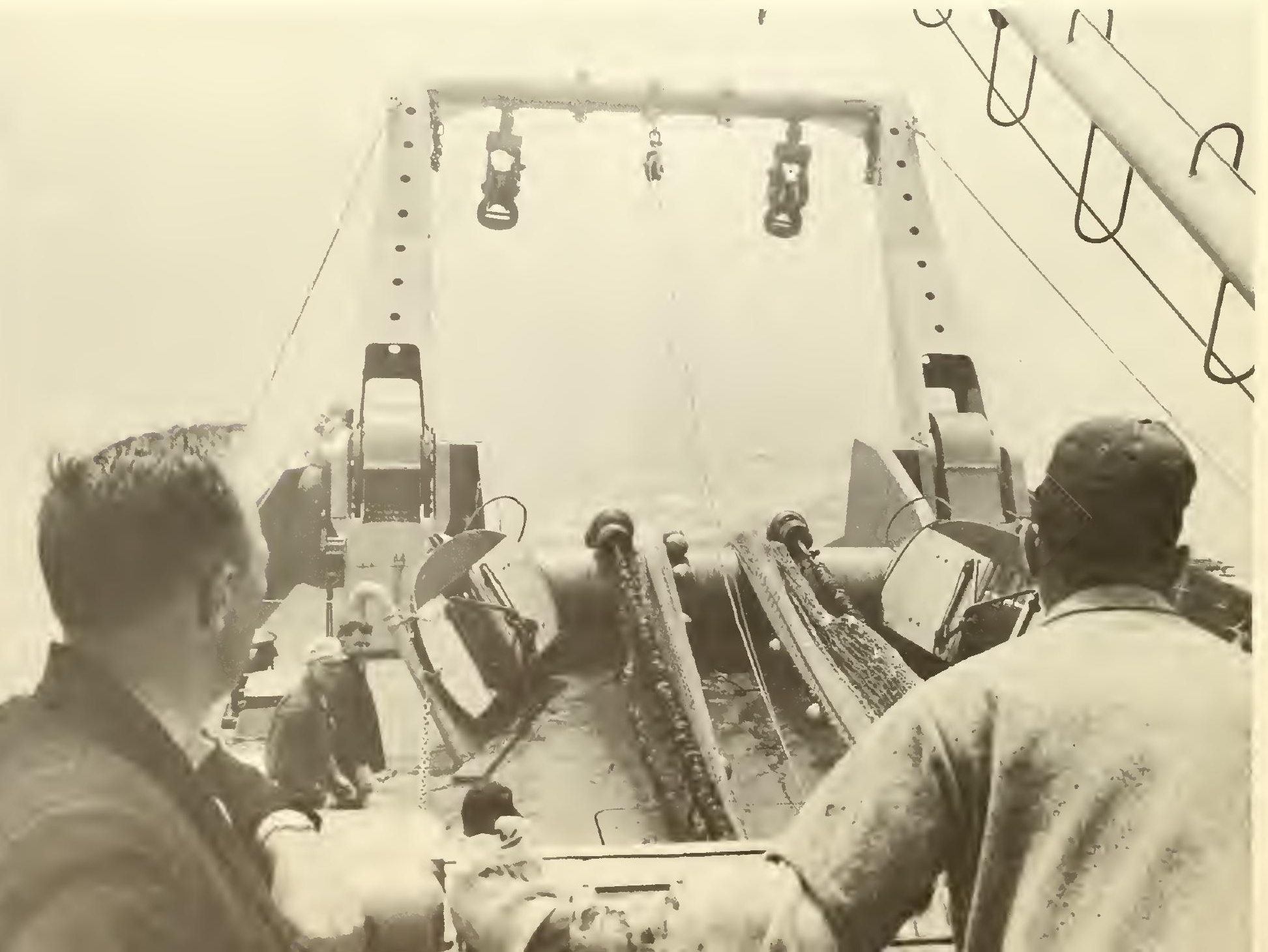


market. He points out that one of their concerns is whether or not these new classes of large vessels can find enough fish in the North Atlantic to enable the ships to work profitably With the size of the ship under consideration, vesscls from 210 to 250 feet in overall length, a minimum of about 12 tons per day must be caught while on the fishing grounds before breaking even. This is an important statistic and one which gives us much food for thought. Mr. Parkes points out that the British are not the only people who are developing these longrange, efficient trawlers; France, Belgium, Holland, U.S.S.R. and West Germany, among others, are rapidly developing distant-water factory trawlers to maintain their competitive position on North Atlantic fishing banks.

The importance of the economics of these large vessels, $\mathrm{Mr}$. Parkes notes, is indicated by the concern of these nations with how much processing equipment nuust be placed aboard the vessels. He speculates that the answer may well be to install no more processing facilities for the production of fish blocks and/or fillets than those which can be kept employed approximately 90 percent continuously while on the fishing grounds. His logic is inescapable. The heary expense of labor and equipment makes it mandatory that on the fishing vessels the equipment be kept in almost continuous operation.

Mr. Parkes states that it is becoming increasingly difficult to find commercial quantities of sizable and edible fish of the types in popular demand. He states that many of the grounds around the coasts of Europe, prolific as recently as 30 years ago, are now commercially barren. He states categorically that the cause is overfishing and the failure to take precautions to allow small fish to pass through the nets. He points out that there can be no worthwhile harvest in the long run if there is not good husbandry of the available stock. His picture of conditions in the North Atlantic - at least the Northeast Atlantic-is pessimistic. He states that management is virtually absent. The industry has received warnings from the scientists, but effective international control is wanting. He suggests there is urgent need of international control of the fishing effort and pleads for effective international enforcement of conservation measures. Essentially, Mr. Parkes says that the increased efficiency of the larger vessels and better gear are simply being used to maintain the previous level of catches. In doing so, he describes some new techniques that the British are using, with sounding and sonar devices as well as trawler speedometers and other electronic equipment of very modern design.

Mr. Parkes emphasizes throughout his discussion the need for more effective international control of fishing intensity and the need for more effective measures of conservation and enforcement. Without these, he sees little future in the fishing industry on those stocks of fish which lave been the basis for the major catches of fish throughout the world. He puts it this way: "Let us hope that our effectiveness as fish killers does not for long continue to outpace our effectiveness as fish conservers." Mr. Parkes has sounded a familiar warning, one with which we can concur. I am sure that I speak for those of us from the three North American countries at this Conference in believing that, in addition to the development and full use of new resources of the sea, there is great potential benefit from

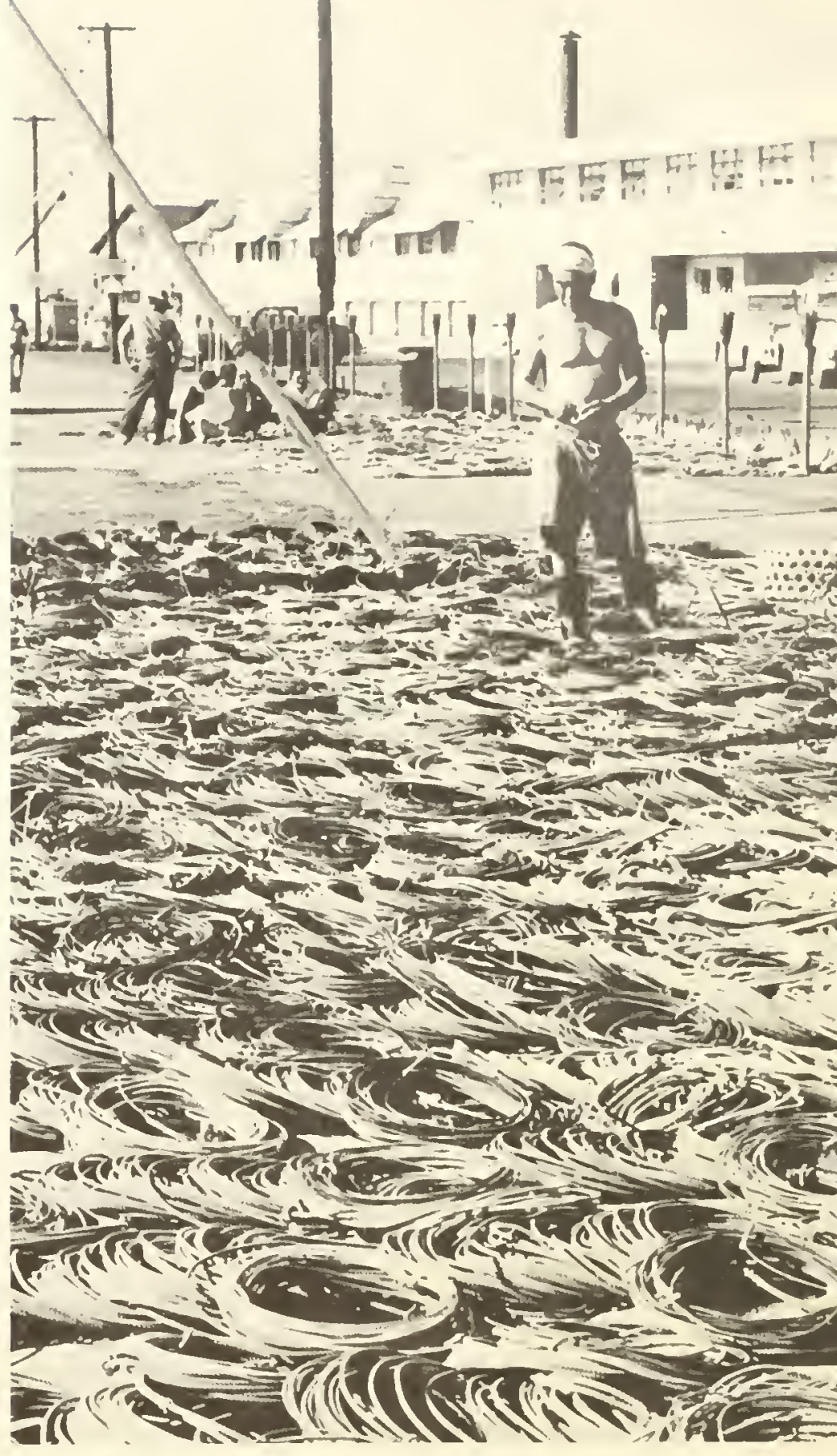

At Kewalo Basin, Honolulu, sampan fishermen dry and repair longline and other equipment on wharf berween cruises.

effective conservation programs to conserve and sustain the economic optimum yield from our fisheries resources.

Moving now to the matter of processing the catch once it is aboard our vessel and reaches our port, Mr. E. Robert Kinney points out that with the tremendous number of trained engineers and scientists in North America one can look toward. new knowledge upon which to base new food products for the consumer of tomorrow. This paper, as have some others, points up the urgent problem caused by the exploding human population on the earth and the ultimate need to look to the 
sea for food. Mr. Kinney points out that in considering the resources of the sea we must become internationally minded and that our research on fishery resources is minimal at best. He points up the responsibility of the processor to watch carefully new developments. The case is made that fish supplies only about 1 percent of the calories needed for food by our population. As he sees it, the fishing industry must compete more successfully and it can do so by improving present methods, developing new products, controlling and reducing labor costs, and recognizing the market for convenience. He goes on to discuss these in more detail, pointing out that the industry must upgrade its products in order to get more of the consumer's food dollars. He thinks that the fishing industry must become more imaginative, crcative and watch new developments-such as the radiation of seafoods, freezing with liquid nitrogen, and freeze drying-and keep a close watch on the development of fish protein concentrate. The industry itself spends too little for research and most of it is in the general field of quality control rather than in evaluation of developments made possible by basic research efforts of scientists throughout the world. Mr. Kinney points out that in order to keep competitive we must increase production efficiency-by automation, design and construction of new equipment and new methods.

He believes the future will bring computers into the fish production lines to control automated filling and dispensing equipment and help produce more uniformly high-quality products in formulation of texture, color, and flavor. This is the channel to the greater consumption of fish in North America and greater profits. He makes a plea for positive attributes in our marketing. He thinks the fishing industry must give the consumer, at some greater cost to itself, more products, more convenience, more nourishment, and more flavor for her monev. He concludes, optimistically, that if the industry is wise enough to utilize fully the research available from our own and sister industries, the rewards in profits and growth will be great.

Speakers on the Marketing Panel projected their thinking into the future so far as marketing was concerned, and presented their views on potential markets and profits if full advantage of opportunities is grasped. The discussion primarily related to the developments in the markets for fish and shellfish within the United States, although there was a recognition, albeit not a great one, of the opportunities for overseas marketing development. Within the last 10 to 15 years, the marketing of seafood products has been revolutionized. A decade or so ago, the bulk of the products, except for a few canned or solid products, was sold on the sea coasts, and relatively little fish was consumed in the Midwest. There, most of the population was unaware of the advantages of fish on the menu.

Mr. John Mehos pointed out that today, from one end of the country to the other, a large variety of fish and seafood items is found on menus of hotels and restaurants and other massfeeding establishments. Everywhere, homes and restaurants serve sea products-domestic as well as foreign-from every corner of the country and globe. While domestic consumption of fish has not increased substantially, the value of fisheries products consumed has increased substantially. Ten years ago, the retail value of fish and shellfish products was about $\$ 900$ million, and today it has reached about $\$ 1.3$ billions, an increase of over $\$ 400$ million. Although this appears fine on first glance, another look shows expenditures for food increased 60 percent, half again as much as the increase for fish and seafood products. In examining population growth and comparing this with the increase in total supply of fish and seafood, it was shown that the total supply consumed in the United States just about kept pace with the population growth. This corresponds very well, of course, with the constant rate of consumption of between 10 and 11 pounds per capita in this country. I would add that, if one looks closer and considers the change in the value of the dollar during the past 10 years, we can scarcely be complacent about the increase in sales of fisheries products during the past 10 years.

It was also shown that the amount of imported products consumed in the United States has gone up tremendously. In 1953, the value of fishery products imported into the United States was approximately $\$ 200$ million. In 1963 , the imports were valued at $\$ 400$ million-an increase of 100 percent. Shrimp was used as a specific example. In 1950, the United States and Mexico produced practically all of the shrimp consumed in the United States. Today, 20 percent of the consumption comes from over 48 countries other than the United States and Mexico. Data show that to a considerable degree the increased imports occurred subsequent to the development of frozen fillets and fish sticks and blocks. With the tremendous increase in consumption of such products as fish sticks, fish portions, breaded shrimp, and other frozen products, there has been a radical change in the type of fishery product consumed in the United States. In addition, it was pointed out that there has been a radical change in the method of marketing. The revolution in marketing fisheries products has altered significantly the kind of products consumed in the home, the packaging of products, and distribution throughout the country. Mr. Eric Turnill visualized marketing prospects in the years ahead. He concludes, much as does Mr. Kinney, that there will be approximately a 23 -percent increase in population of the U.S. by 1975, reaching about 230 million people, not counting increases in Mexico and Canada. But Mr. Turnill also points out that there will be a great deal more money in the pockets of each family, and that the spare money is increasing at a faster rate than the basic income. To him this means that Americans are going to be in a position to spend more money for food, and they are going to want better, higherpriced, and more convenient foods to serve. He foresees that the American housewife will buy more precooked portions of shrimp, lobster, crab, halibut, salmon, and other products which may be produced in the future. He estimates, and I assume his statistics to be correct, that Americans will probably spend 75 percent more for foods in 1975 -just 10 years from now. And, it seems quite logical, people will spend more for food away from home, at hotels, restaurants, clubs, and drive-in restaurants. The housewife will do almost all her buying in self-service supermarkets. Mr. Turnill predicts, on the basis of Bureau statistics, that there will be more than $5 \frac{1}{2}$ billions of pounds of fish and shellfish available to sell in 1975. Since the statistics come from our Bureau, I take them to be correct 
by definition. On the other hand, these statistics are only' true if we continue to sell fish at the same low rate as today. He then concludes that in the next 10 years the size of our market will increase by 25 percent; Americans will have 75 percent more money to spend on food; we are going to lave more products to market than at the present; and the important point for the American fishing industry to remember is that the housewife must be presold before she shops, and this will be tough to do because there will be more competition for the consumer dollar.

Dr. Wendell Earle presented a stimulating discussion of "Marketing at a Profit." The thrust of his argunent was that there are bound to be changes in marketing practices in the

A shrimp catch of over 500 pounds being landed aboard the charter vessel $M / V$ Yaquina in Yakutat Bay, Alaska.

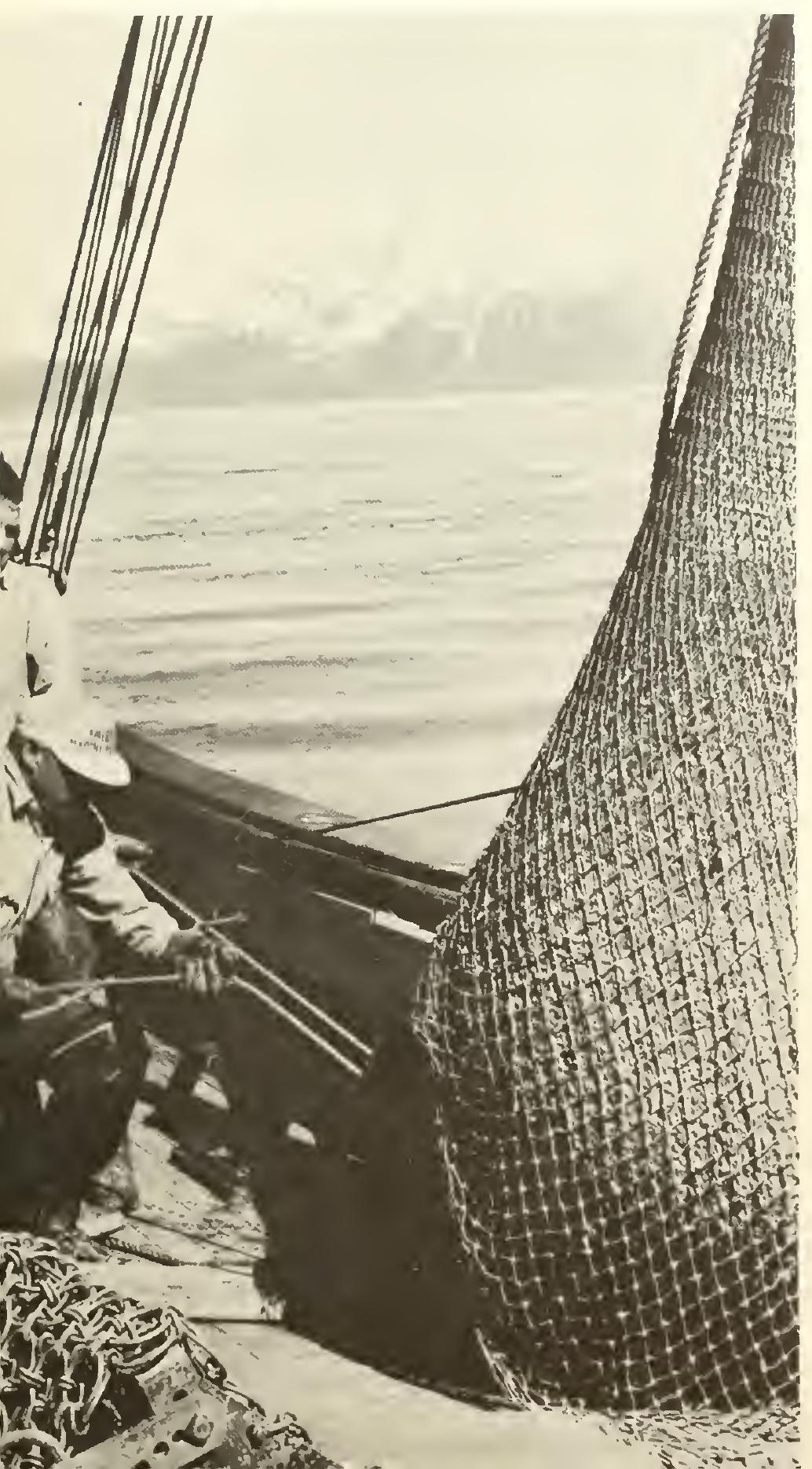

next few years; these will not be radical but will involve further evolution in the growth of the frozen and convenience foods markets. Dr. liarle, critical of present-day pritctices, quotes a speaker who wrote of marketing men as men persisting in marketing a product as though the population was made up of "white Protestant, middle class, young, suburban corporation executives and their wives," when in fact present-day markets are composed of many quite distinct groups, each a separate market.

His picture of the great numbers of Americans who do not eat fish at all, or very seldom, strikes at the heart of the marketing problem of the fishing industry.

I would say after hearing his arguments that Dr. Earle accuses us, and I judge us guilty, of utter complacency. His answer to the industry's problem is that we need more outstanding products and an advertising program of greater magnitude than that now underway. Here he is not talking about increasing the industry-wide promotion allowance from $\$ 50,000$ to $\$ 100,000$ per year. He talks in terms of $\$ 500,000$ per year. I think he is way too low.

I am well aware of the advertised brands expenditures for advertising canned and frozen fish. But the industry is still essentially composed of small businesses, so it seems obvious that they must join with the larger components and support a significant program. I don't believe this is being done now and, obviously, neither does Dr. Earle.

He raises another very significant point. In again quoting a colleague, he points out that profits come from three sources in the food chain: the markup on commodity, improvements in production efficiency, and increases from marketing services. He believes the fishing industry is neglecting the profits to be gained by marketing services and his arguments seem sound to me.

In summary, Dr. Earle presented stimulating arguments which tend to corroborate the consumption statistics; we are not doing a very good job of marketing our products; we are overlooking profitable ways to improve the marketing; and we are not putting one-tenth enough effort (money) into industrywide promotion. With these arguments before us, there is little wonder that the per capita consumption of fish remains constant in the United States and Canada.

Mr. Murray Wheeler, with Mr. Frohman, reviewed some excellent advertising and promotion worl done the past year. I must confess that his report was most encouraging. There can be no question but what well-supported promotion and advertising will sell high-quality fishery products. My résumé of this section of the marketing presentation is that there is a great enthusiasm, a tremendous opportunity-an opportunity which requires two things: a greater quantity of high-qualit! fisheries products for the martiet and increased support by the fishing industry of marketing promotion and direct advertising. I am reminded here of the oft-repeated poen about the codfish. I believe our marketing experts have mentioned the promotion activities of the poultry and dain people. What they meant to say is that we in the fish business could do a great deal more crowing. I think we can, too, especially when I think of the poem about the codfish and the hen: 
"The codfish lays a thousand eggs,

The homely hen lays one,

But the codfish never cackles

To tell you what she's done.

And, so we scorn the codfish,

While the humble hen we prize.

Which only goes to show

That it pays to advertise."

I suggest if we can't put more money into industry advertising, that as a last resort we attach air horns to the air bladders of codfish. At least we will make more noise.

Minister Sharp discussed, in general, the advantages of increased trade among all nations, and especially among American nations. He pointed out that about onc of five dollars Canada carns comes from exports. It was quite clear from his discussion that Canada is very dependent upon trade, and her trade in fisheries is very large.

The Ministcr discussed the Kenredy Round Tariff ncgotiations now underway in Europe. He was cautiously optimistic that this would be successful after periods of disappointment and trials. It was his view that these talks would lead eventually to an improved trade climate among nations and he saw fisherics trade cxpanding as a result.

While the preceding gentlemen talked primarily about domestic markets, Secretary of the Interior Udall talked about the developing world markets and the challenge the United States fishing industry faces in competing for the world markets of tomorrow. He pointed out that the international trade in fisheries products is growing, and growing rapidly-- that the volume of world exports in 1963 was almost three times as great as in 1948 and 60 percent larger than in 1958. North America and Europe combined bought about 83 percent of the total volume of world imports of fish in 1963. In contrast, Africa, Latin America, and Asia together - these, of course, are countries with relatively low purchasing power-accounted for only 14 percent. Secretary Udall recognizes that the current negotiations, called the "Kennedy Round Tariff Negotiations," will undoubtedly impose some immediate economic hardships on our domestic fishing industry. But, provided the fishing industry accepts the challenge, a reduction in trade barriers will make possible new opportunities for overseas trade by the American fishing industry. He views the increased world harvest of fish as a possible means of meeting the problem of hunger throughout the world. With the recent accumulation of scientific information about the sea, it secms obvious to him that our industries - the industries of the three countries here at this Conference - can be made ready for ocean development programs, translating scientific knowledge into an ever-increasing harvest of mineral, food, and water resources from the sea.

In order to make this vast potential food resource available to hungry people, we in our three countries must develop more highly sophisticated systems of trade and aid-systems which require international cooperation as well as cooperation between Government and private business. He believes that fish can play a decisive role in these programs through the development of private trade as well as through overseas aid, such as Food for Peace and other programs. Secretary Udall believes that as developing countries achicve economic growth, active markets for fisheries products develop. He points out that industry must develop new kinds of products-those based upon new technology, such as freeze drying, irradiation, and reduction products-along with conventional, economic canned and cured products for use in growing markets in rapidly developing countries. He looks upon fish protein concentrate as providing great opportunities for industry in this country. He believes that we are on the threshold of marked improvement in both developing a fish protein concentrate as well as finding uses for it in human diets. He looks upon this as a way of bringing into commercial use many species of fish now entirely or partially unutilized. In summary, Secretary Udall believes that the American fishing industry has a tremendous challenge to develop world markets for fishery products. He, like a number of our speakers on the panels over the past 3 days, sces improved technology and increasing efficiency as the key to successful competition on the world market.

There were two additional papers of great interest and concern to the Conference. The first of these was by Mr. Robichaud, Minister of Fisheries for Canada. Mr. Robichaud's message involved a most stimulating discussion of the need for conservation and wise management of world fishery resources. He warns us that the mobile fleets of large fishing countries pose a serious challenge to the somewhat inadequate world organization for conservation of international fisheries research and regulation. He points out that although there are some outstanding examples of the conservation of fishery resources, examples in which both the United States and Canada participate, there are storm clouds overhead brought about by the increasing competition for common resources. His discussion of various fisheries commissions in which Canada participates leads him to conclude that, in order to meet the challenge, some kind of mechanism much broader than the regional commissions now in being must be developed in order to safeguard the living resources of the sea in the future.

Mr. Rochichaud sees an important role for the FAO to play: in gathering comprehensive statistics of all fisheries and stimulating the exchange of scientific information on a very broad basis. He emphasizes that the rapid expansion of world fisheries will continue; that this creates an urgent need for strong unified conservation efforts; and that we of the Americas face a great challenge. He points out that if we meet this challenge effectively, future generations will benefit. But, if we fail, our generation will share the blame. Minister Robichaud expresses Canada's determination to play her part in winning the battle for international cooperation in fishery conservation.

Mr. Jackson has spoken to us this afternoon about the role of FAO in world fisheries. I need not repeat his summary of the explosive character of world fisheries today, but I should mention that $\mathrm{Mr}$. Jackson quite clearly lays out the imbalance in the harvest of fish by a very few countries. For example, he points out that nearly one-third of the world catch in 1963 was taken by 2 countries-Peru and Japan-and that two-thirds of the world catch was taken only by 10 countries out of some 
220 countries in existence today. Hc presents somc other interesting statistics to show that there is an imbalance in the catch of food from the sea, not only in the amount taken by a few fishing countries but in the distribution of the fish catch.

Mr. Jackson points out that world fisheries are in the midst of a technological revolution. The catch has increased, vessels are increasing in number and in size, the number of products and thcir distribution has increased exponentially in the last few years. This, however, is happening only in few places; the overwhelming majorities of nations and pcople have bcen left far bchind. This results in 95 percent of the world catch being taken by about 20 percent of the countries.

Mr. Jackson also deals with the international trade problem. His gencral arguments are much the same as those of Secretary Udall. He points out, for example, that if one considers the live-weight cquivalent of the fisheries catch, one-third of the total world catch was entering international trade scven years ago, and in 1962, the figure had risen to about 40 percent. Another way of putting this is that for every five tons of fish caught now, two are exported. A surprising statistic came from Mr. Jackson. He estimates that the volume of fish and fishery products traded internationally is now of about the same order of magnitude as the international trade in meat. He points out, quite rightly, that fisheries differ from agriculture and meat production in that, for the most part, the fisheries stocks of the world are common property of mankind and, therefore, they are highly international in nature.

After reviewing the general kinds of work that FAO does, Mr. Jackson strongly implies, and it is an implication that I am perfectly willing to accept, that the FAO fisheries group is wholly inadequate to accomplish the task before them. Their problens of dealing with regional fisheries bodies and technical assistance of various kinds, and attempting to be responsive not only to the needs of the developing countries but to others-by bringing together scientists as well as scientific information for the developing countries-pose a task far beyond the capability of their present staff. He has pointed out that there are moves on foot, and I am pleased to be able to say that the United States Government has been in the forefront of these moves, to upgrade fisheries and provide adequate tools for this potentially important international organization. He believes that FAO's role should be one of leadership through service, and he has summarized some of the duties of this organization as he sees it. My own view is somewhat similar to that of Minister Robichaud's. In the future, fishing countries must look to some kind, or kinds, of international organization, broader than those now in being, to provide a common forum for fishing nations to wisely consider conservation measures for the living resources of the sea. I am not sure that FAO is in fact one of these organizations of the future, but I insist that they should have the opportunity to develop along these lines.

I have tried thus far in summarizing the Conference to more or less highlight the papers of preceding speakers, inserting what appeared to me to be pertinent comments; to others, they may have seemed impertinent. Now I should like to attempt to summarize the Conference in my own words.
Turning to the resource, it seems quite obvious that there is ample opportunity for a twofold to tenfold increase in the sustainable catch of fishery resources from the world ocean and from the scas surrounding our shores. The question raiscd by several of our distinguished speakers is how to achieve this increase economically; by what means; and several have pointed out that this can only happen when products and a market for those products have bcen found.

There is no simple answer to the disturbing questions raised by Dr. Kask. It seems quite obvious that the fishing industries of at least Canada and the United States harc not kept up either with other food-producing industries in our countries or with many important fish-producing nations of the world. It has bcen shown that the reasons for this are complex. They involve the political, economic, and social custons and regulations of our countries. The rules under which we can fich and sell our products have been so manipulated that we are handicapped in relation to other fishing nations in developing the most efficient kinds of gear and harvesting the resources to the maximum extent possible, consistent with proper conservation.

Several speakers have pointed out that the resources of our coasts were being utilized by large fleets from foreign lands. One speaker has told us, in a sense, to get off our pants and start fishing before we lose our industry. It has been suggested that the organizations of our Government-Federal and State - are not completely adequate to handle the problems of complex international fisheries of tomorrow, and that certain changes ought to be made in order to improve our chances. I do not quarrel with these views nor for the need for change. However, I am not certain that we have considered all the roadblocks to increased production nor the changes in our fisheries which are taking place. For example, there is a move towards the consolidation of the small, independent fishing unit within our own country, and I presume the same thing is happening in Canada and Mexico.

The problems of the small, independent operator-be he fisherman or processor-have been pointed out by a least one of our speakers in the last three days, and it seems to me that whether it is good for the country, good for the fisherman, or good for the processor, there are some business advantages in the larger units within the industry. The larger entrepreneurs have more capital for adequate investment, for carrying large inventories, and for withstanding the shock of fluctuating supply and demand which is so characteristic of the fish business.

The consensus of our Conference seems to be that we need better and more diversified products. These seem to be developing slowly in the form of fish portions, shrimp products, fish protein concentrate, and others. Most of our experts did not think we were doing nearly enough to develop new products nor to improve the quality of those we now sell.

Some speakers were optimistic about the marketing potential, but neither Dr. Earle nor I am very happy. We see our countries falling hopelessly behind other fishing nations in catching, marketing, and in the consumption of fish-despite the rosy picture of fish sticks and portions, shrimp products, canned tuna, and another one or two products. 


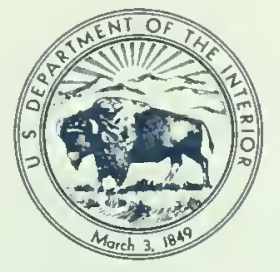

Created in 1829, the Department of the Interior-

a Department of Conseriation - is concerned with the management, conservation and development of the Nation's water, fish, wildlife, mineral, forest, and park and recreational resources. It also has major responsibilities for Indian and Territorial affairs.

As the Nation's principal conservation agency, the Department works to assure that non-renewable resources are developed and used wisely, that park and recreational resources are conserved for the future, and that renewable resources make their full contribution to the progress, prosperity, and security of the United States . . . now and in the future.

UNITED STATES DEPARTMENT OF THE INTERIOR Stewart L. Udall, Secretary

FISH AND WILDLIFE AND PARKS

Stanley A. Cain, Asst. Secretary

FISH AND WILDLIFE SERVICE

Clarence F. Pautzke, Commissioner

BUREAU OF COMMERCIAL FISHERIES

Donald L. McKernan, Director

Circular 250 September 1966

Published by the Bureau of Commercial Fisheries

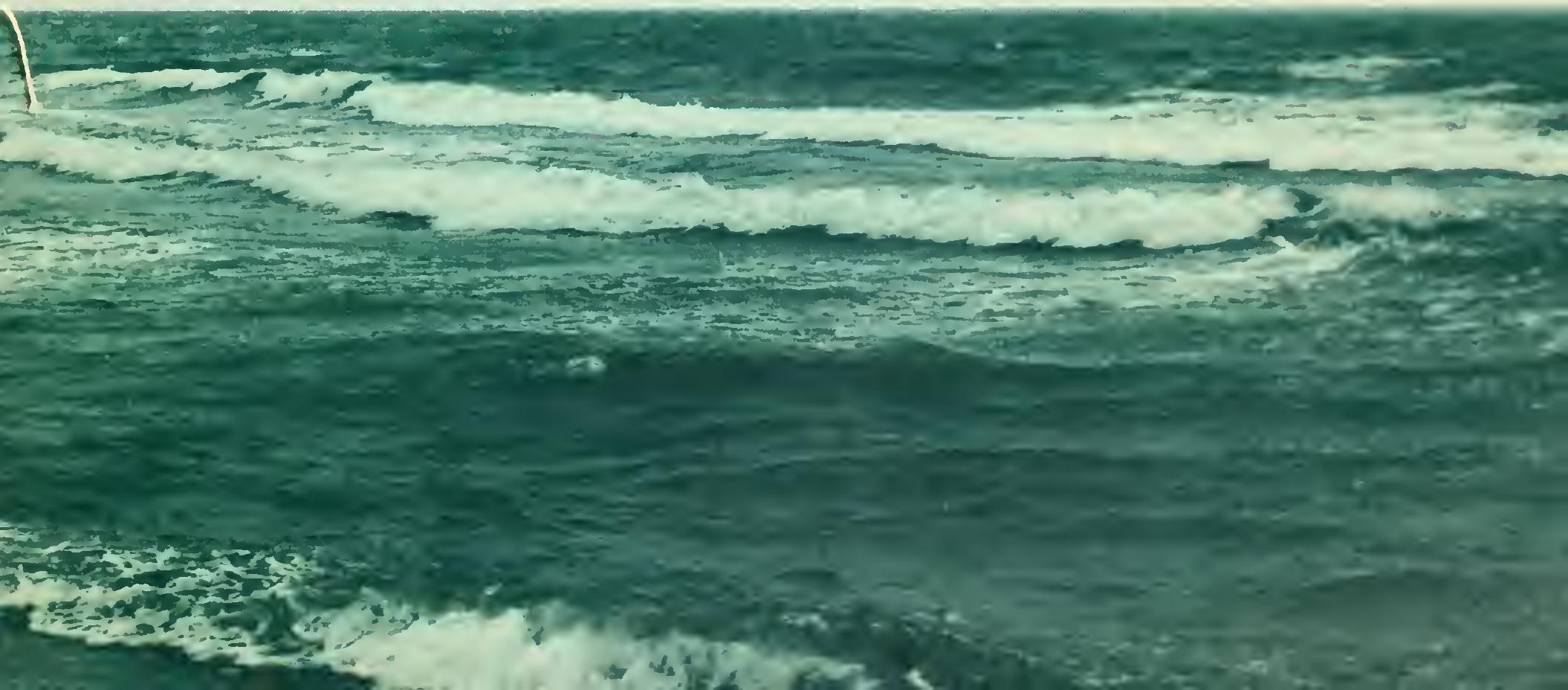




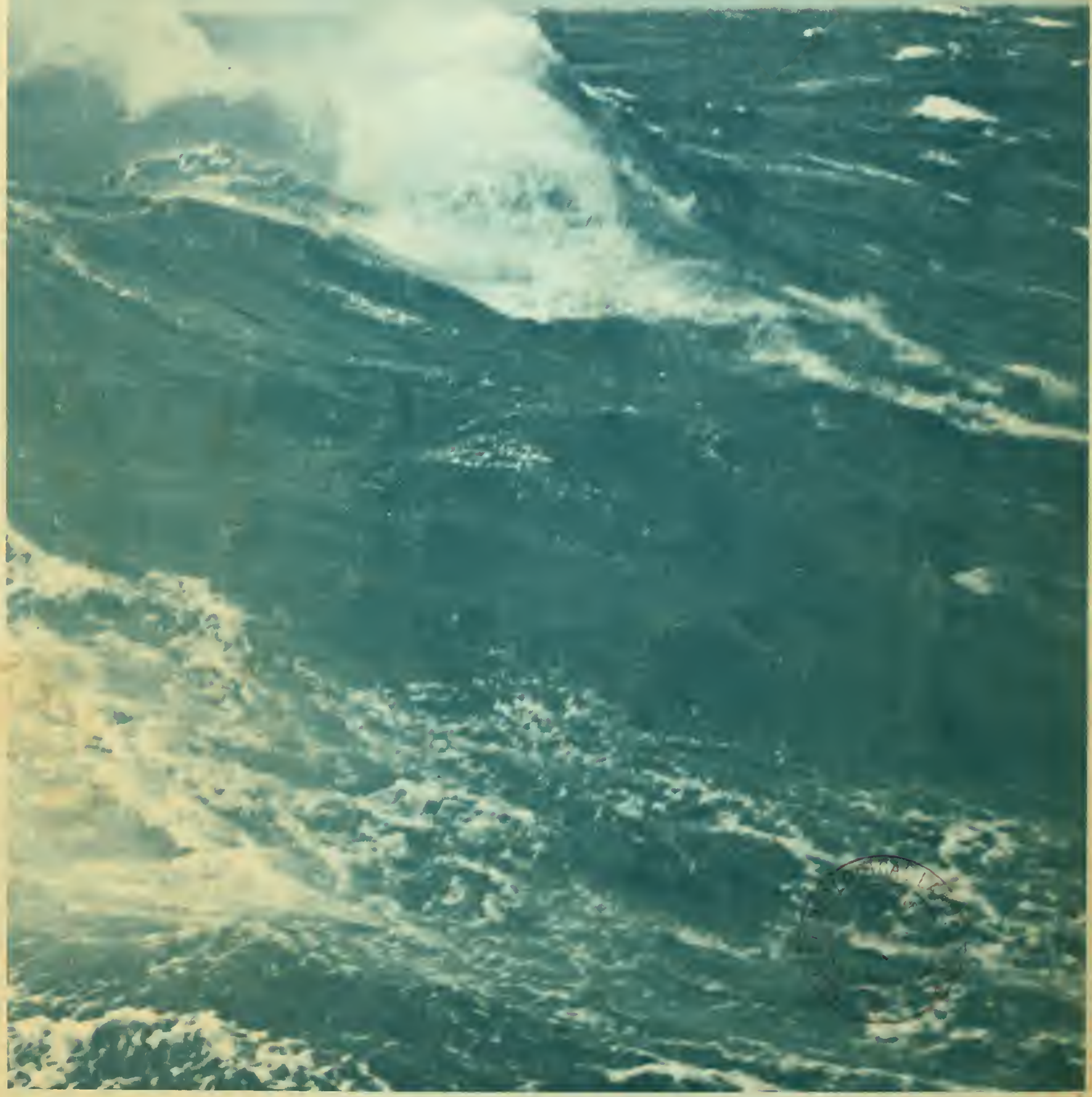

